\title{
PrimeEnergy/DOE/GRI Slant Well
}

Final Report
C.E. Drimal
G. Muncey
R. Carden

Work Performed Under Contract No.: DE-FC21-88MC25146

\author{
For \\ U.S. Department of Energy \\ Office of Fossil Energy \\ Morgantown Energy Technology Center \\ P.O. Box 880 \\ Morgantown, West Virginia 26507-0880
}

PrimeEnergy Corporation

One Landmark Square

Stamford, Connecticut 06891

December 1991 


\title{
PrimeEnergy/DOE/GRI Slant Well
}

Final Report

\author{
C.E. Drimal \\ G. Muncey \\ R. Carden
}

Work Performed Under Contract No.: DE-FC21-88MC25146

\author{
For \\ U.S. Department of Energy \\ Office of Fossil Energy \\ Morgantown Energy Technology Center \\ P.0. Box 880 \\ Morgantown, West Virginia 26507-0880
}

PrimeEnergy Corporation

One Landmark Square

Stamford, Connecticut 06891

December 1991 
3. Angle-Build Section ............................................................................................. 11

4. Slant Section ....................................................................................................... 12

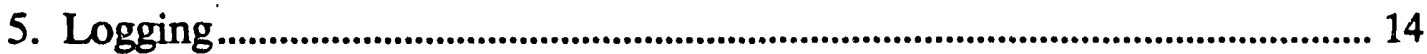

III. Completion and Stimulation......................................................................................... 14

IV. Reservoir Properties ......................................................................................................... 15

V. Production ......................................................................................................................... 17

Vl. Project Cost ......................................................................................................................... 19

VII. Project Economics ............................................................................................................ 19

VIII. Summary and Conclusions ........................................................................................... 26

IX. Appendices

A. Daily Drilling Reports ...................................................................................... 28

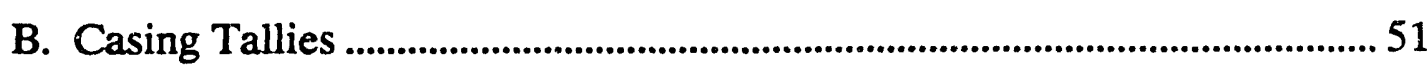

C. Drill Pipe Tallies....................................................................................................... 55

D. Motor Performance and Bottom Hole Assemblies ....................................... 59

E. Bottom Hole Assembly Data ................................................................................. 63

F. Build and Walk Rate Data ........................................................................6 67

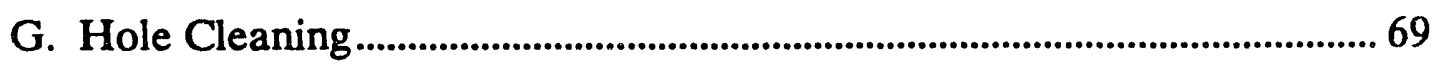

H. Drilling Mud Reports (Foam Data)............................................................. 72

I. Pressure Build-up Analysis.................................................................................. 78 


\section{EXECUTIVE SUMMARY}

This report presents final results of the high-angle Devonian Shale development well arilled under DOE contract number DE-FC21-88MC25146. The well was drilled in Roane County, West Virginia on the foreland flank of the Chestnut Ridge Anticline; a structure closely associated with a fairway of locally significant Devonian Shale gas production. The target of the well was a tabular, southeastdipping, fractured zone near the top of the Lower Huron Member of the Devonianage Ohio Shale.

The well was conventionally drilled to a kick-off point of 2,150'. Positive displacement motors were then used to build inclination, at an average rate of 9 degrees per 100', to an inclination of 67 degrees at a true vertical depth of 2,954'. Conventional rotary assemblies were then used to drill the slant section of the well across a 1,500' target section to a true vertical depth of 3,571'. Inclination in the slant section varied from 67 to 72 degrees. Total measured depth of the borehole was $4,833^{\prime}$.

Hydraulic fracturing treatments were performed in four separate stages. Stimulation intervals ranged in length from 6 ' to 570'. Each interval was treated with straight nitrogen in volumes ranging from $1,303,000$ to $1,800,000$ standard cubic feet after breakdown with 400 to 500 gallons of $7.5 \%$ acid.

Estimates of open flow from all zones summed to approximately 1,400,000 cubic feet per day; an apparent three-fold improvement over the average vertical well in the area. Post-stimulation flow rates summed to about 195,000 cubic feet per day against simulated line pressure, but were not sustainable at that level under producing conditions. Unexpected oil production of approximately 1 barrel per day has had a substantial detrimental effect on gas deliverability. Operational aspects of gas production have been complicated, and gas deliverability reduced, by the periodic buildup of hydrostatic pressure due to accumulation of oil in the wellbore. Moreover, gas flow into the wellbore may be significantly curtailed due to relative permiability of the reservoir rock to oil and gas.

Cumulative production for the period September 1990 through August 1991 totalled $5,750,000$ cubic feet of gas and 493 barrels of oil. In contrast, production of nearoffset vertical wells ranged from $5,200,000$ to $53,500,000$ cubic feet of gas, and no oil, during an equivalent 12-month period.

Lower-than-expected gas deliverability suggests that neither high-angle drilling nor subsequent hydraulic fracturing treatments were successful in connecting the borehole with the natural fracture system(s) encountered in near-offset highdeliverability vertical wells. This, combined with a borehole which met virtually all of its design criteria, suggests that the vertical-well-based reservoir model failed to adequately predict fracture distribution within the reservoir. Furthermore, the apparent absence of fractures predicted by the vertical-well-based reservoir model suggests that Devonian Shale fracture systems, at least in the study area, may not exhibit sufficient continuity along strike and/or depth for directional drilling to produce an economic benefit. 


\section{INTRODUCTION}

This report presents final results of the Sterling Boggs 1240 slant well. The Boggs 1240 was drilled under DOE Cooperative agreement number DE-FC21$88 \mathrm{MC} 25146$ as a part of an ongoing DOE investigation of directional drilling in the development of marginal gas resources. The United States Department of Energy and PrimeEnergy Corporation (successor to Sterling Drilling and Production Company) developed a cost sharing contract under which the high-angle well would be drilled, logged, tested, and stimulated. Early-on in the project the Gas Research Institute (GRI) joined as a research participant to conduct supporting research in well siting, well logging, testing and stimulation, and PrimeEnergy was joined by Columbia Natural Resources, McCormick Resources, and the Pennzoil Company as working interest partners.

Objectives of the project were (1) to test the potential for improved recovery efficiency in a fractured Devonian Shale reservoir from a directionally drilled well, (2) to perform detailed tests of reservoir properties and completion methods, and (3) to provide technology to industry which may ultimately improve the economics of drilling in the Devonian Shale and thereby stimulate development of its resources.

This report updates information presented in earlier papers (Muncey, 1989, Muncey and Carden, 1989, and Muncey, 1990) regarding the background, plans for, and results of the slant well project. Like the earlier papers, this report is influenced by the investigations of Lowery et al (1988) and Sweeney (1986) and by communications with many government and private-sector scientists and engineers.

The report is divided into eight sections. In Part I the geologic setting and site selection are discussed. Drilling plans, a detailed discussion of drilling operations and logging are presented in Part II. Completion and stimulation are discussed in Part III and resevoir properties are discussed in part IV The well's production history and projected performance are topics of Part V. Project cost and economics are presented in Parts VI and VII respectively. Finally, project findings are summarized and conclusions are presented in Part VIII.

\section{SITE SELECTION}

The primary objective of the project was to test the potential for improved gas recovery from a fractured Devonian Shale reservoir from a directionally drilled well. Historically, Devonian Shale wells have been drilled vertically. Within a given population of Devonian Shale wells, drilling results have typically shown large variances in reserves with low reserves per borehole on average. Moreover, because of the low average reserves per borehole, drilling in the Devonian Shale has tended show poor economic results. Over time operators have recognized that wells with relatively high reserves intersected with one or more naturally occurring fractures. It was also recognized that relatively few wells connected with these fracture systems because they tended to have a largely vertical orientation, making them a difficult target for conventional vertical drilling. 
To test the potential for improved recovery with directional drilling, the plan was to select a fracture-prone area using available geological data, map a high-productionpotential fracture system utilizing data from near-offset vertical wells; then drill across the strike of the mapped fracture system. It was hypothesized that (1) by drilling across the strike of the mapped fracture system, the probability of intersecting multiple high-potential fractures would be increased substantially, and (2) that multiple fracture systems encountered by one borehole could then be stimulated with hydraulic fracturing techniques. It was further hypothesized that the combined effect of conditions (1) and (2) would result in sufficiently improved recovery efficiency to make such drilling economically feasible. This concept is illustrated schematically in Figure 1. Moreover, it would provide the opportunity to conduct additional research on reservoir properties and completion methods. It would also provide a case study for operators on the application of directional drilling technology in the Appalachian Basin.

Accordingly, primary site selection criteria were: (1) that the selected location be in an area with known fracture-controlled Devonian Shale gas production, (2) where fractures were intersected by vertical wells, that production be of sufficient quality to make a commercial vertical well, (3) that there be sufficient well control to substantially mitigate exploration ("dry-hole") risk, and (4) that there be sufficient geological control to define a drilling target which offered a high probability of intersecting with production-controlling fractures.

A project area located in the Geary district of southeastern Roane County, West Virginia was selected. The well location and surface expressions of local structural features are presented in Figure 2. The project area lies within the Alleghany Plateau structural province. Structural style of the area is dominated by the intersection of two regional structural elements; an Alleghanian detachment, defined by the north to northwest-striking Burning Springs and Mann Mountain thrust sheets, and a northeast-striking system of relatively low-amplitude folds which overlies the southern boundary of the Rome Trough (Lowery et al, 1988). Additional structural complexity arises from a jump in stratigraphic position of the basal Alleghanian detachment from the Silurian Salina Salt level at the Burning Springs anticline to the Devonian Marcellus (?) Formation or perhaps to a subSalina Salt position beneath the Mann Mountain Anticline (T.K. Reeves, personal communication).

The well was drilled on the foreland flank of the Chestnut Ridge Anticline, approximately at the intersection of the Alleghanian front and the Rome Trough trends; a location thought to offer good opportunity for locally enhanced fracturing. In order to minimize exploration-type risk, the wellsite was located in an area with good well control within a narrow, relatively high-production-potential fairway. The presence of the narrow high-production fairway suggests the influence of vertical or sub-vertical fractures on the reservoir. Evidence corroborating the existence of such fractures is seen in well logs from the offsetting vertical wells (Lowery et al, 1988).

The high-production fairway is illustrated schematically in Figure 3 which shows the surface location and approximate azimuth of the Boggs 1240 wellbore with 12month cumulative gas production as mapped from offsetting vertical wells (i.e., as mapped before drilling the Boggs 1240). Contoured values are in millions of cubic feet (MMCF). Dashed lines represent traces of faults, on the top of the Lower Huron, interpreted from repeat sections observed in offset wells (Lowery et al, 1988). 


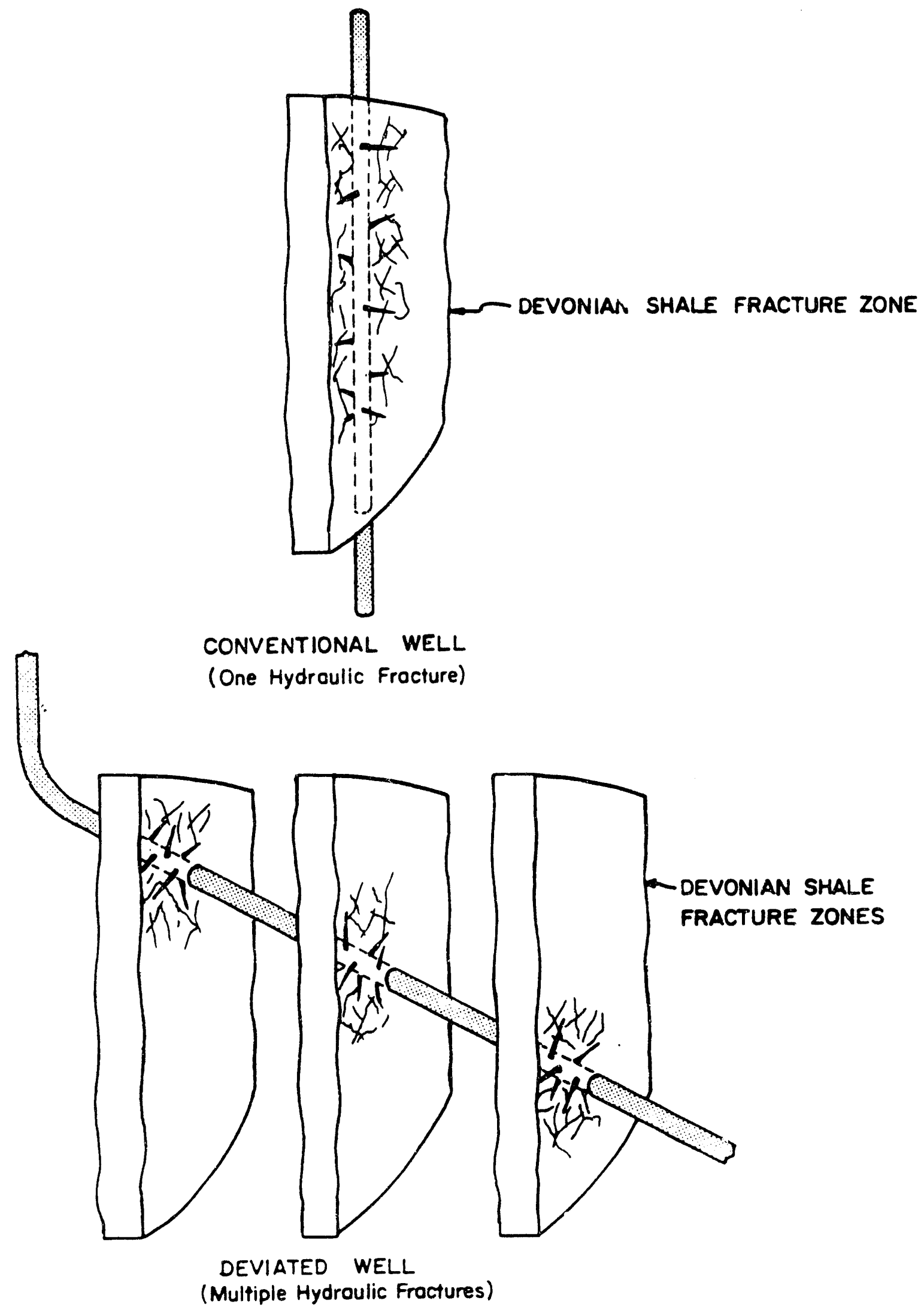

Figure 1. Multiple Hydraulic Fracturing Potential for a Deviated Well 


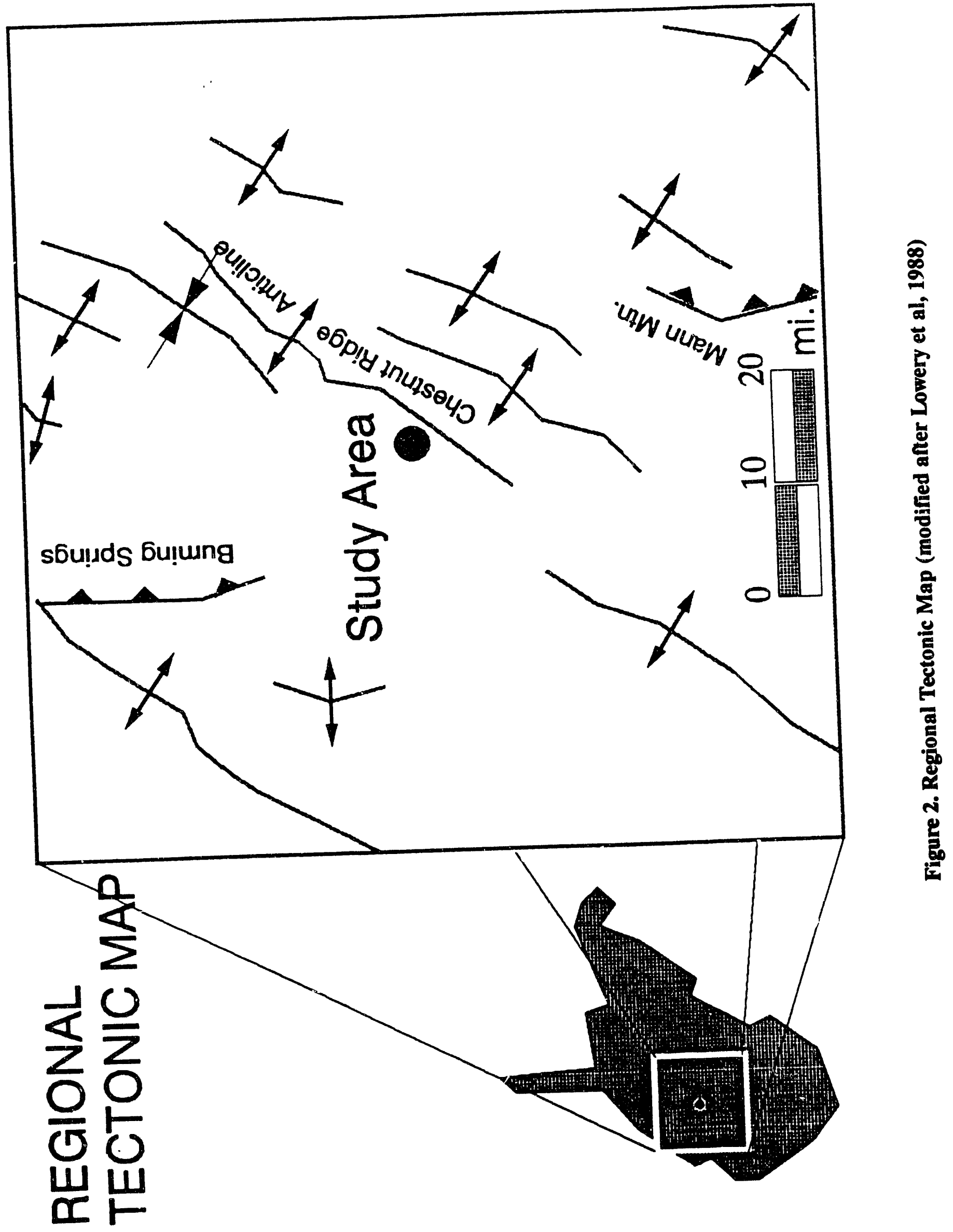




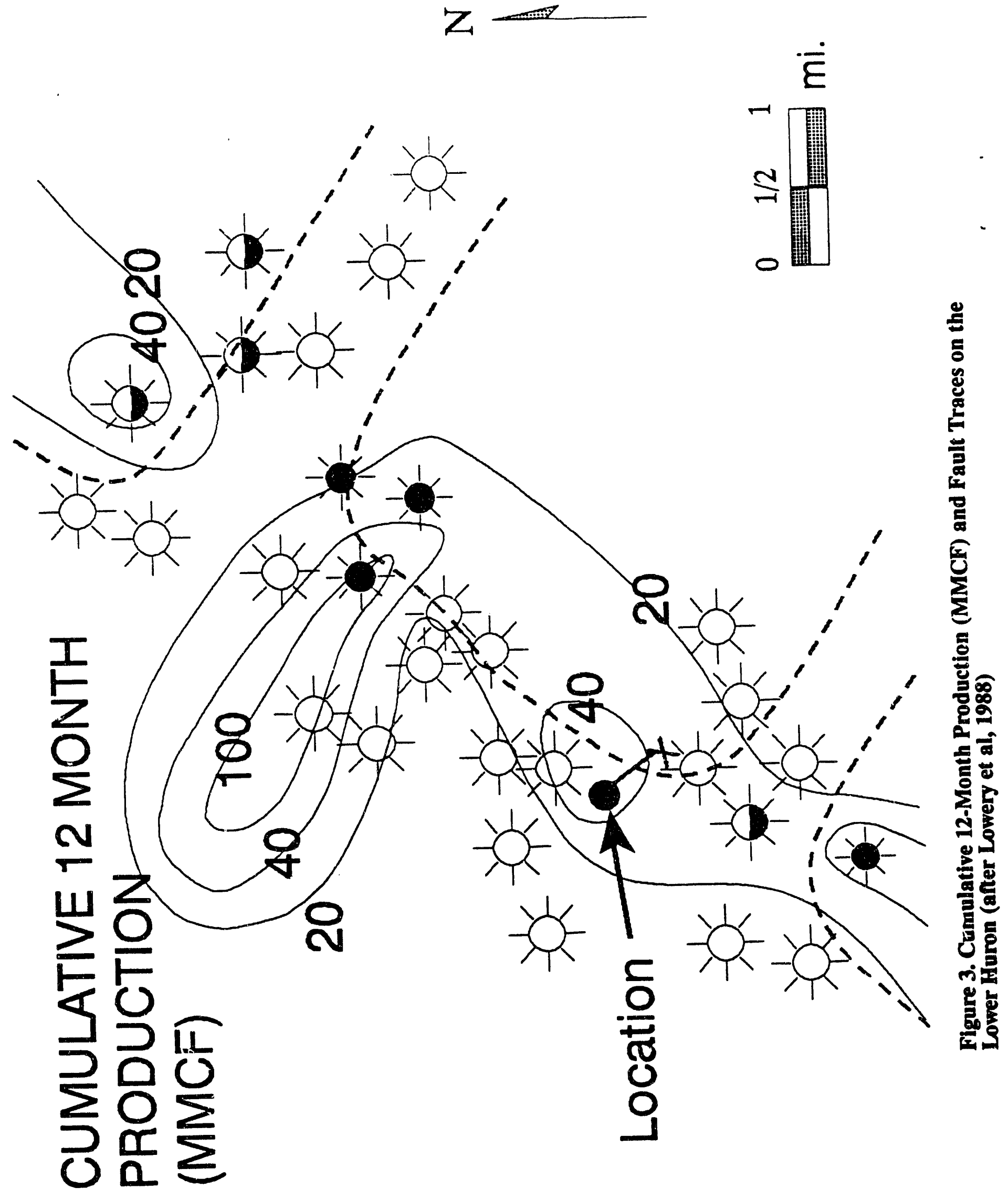


First year cumulative production in the area ranges from a high in excess of 157 MMCF to lows of less than 3 MMCF. First year cumulative production is highly variable within the fairway, but a strong systematic correlation with the structural fabric can be observed. It is apparent that the northeast component of the local structural fabric is the dominant influence on the reservoir, and hence that the northeast-trending fractures are of primary importance in the reservoir system. However, it is also apparent that some of the better wells may be associated with a northwest structural trend that has been correlated with Alleghanian shear faulting (Lowery et al, 1988).

No drilling locations were available with proximity to prospective northwesttrending structures. Therefore, a location was selected within one of che stronger production anomalies associated with the northeast trend. Data from offsetting vertical wells was used to map a tabular, southeast-dipping, fractured zone near the top of the Lower Huron Member of the Devonian Shale. A wellbore trajectory was then designed which was to maximize potential for borehole intersection with the production-controlling fracture system(s).

\section{DRILLING OPERATIONS}

\section{SUMMARY}

Figure 4 presents a schematic of the project-well design, the target zone as envisioned from offset well data, and the actual wellbore as drilled. On the vertical axis is true vertical depth - beginning at 2,000' subsurface. On the horizontal axis is horizontal departure. Stratigraphically, the kick-off point (KOP) is just above the top of the Upper Devonian Undivided at about 2,100' subsurface. The target zone is located within the lower few hundred feet of the Upper Devonian Undivided and the upper $100^{\prime}$ of the Lower Huron member of the Devonian Shale. Figure 5 presents the planned and actual wellbore trajectories in planview.

Well design targets were (1) to be at $68^{\circ}$ inclination by $2,950^{\prime}$ true vertical depth (TVD), plus or minus $50^{\prime},(2)$ to attain a lateral departure of $600^{\prime}$ plus or minus $50^{\prime}$, by $2,950^{\prime}$ 'TVD with a target angle-build rate of $8.6^{\circ}$ per $100^{\prime}$ using a double-bend motor assembly and steering tool, and (3) to drill across the target zone building angle at about $0.5^{\circ}$ per $100^{\prime}$ using a rotary assembly. The total planned measured depth was to be $5,160^{\prime}$ (3,426' TVD).

Drilling operations were conducted at the site between July 10, 1989 and August 1, 1989. The vertical portion of the well to the kickoff point took one day longer than anticipated. The build section required seven days to drill and was the same as the planned time. An additional two days were needed to drill the slant section because of a motor correction made at 3,785' as the borehole had begun to walk to the left (east), getting too close to the adjacent lease and threatening the prospect of too little lateral departure. The wellbore length was $327^{\prime}$ shorter than the planned wellbore $\left(5,160^{\prime}\right.$ planned vs. $4,833^{\prime}$ actual). Total days on location were 23 compared to the anticipated time of 20 days. Planned versus actual drilling days were as close as can reasonably be estimated for a well of this nature. Figure 6 is a plot of depth versus days for the actual and planned drilling programs.

Daily drilling reports can be found in Appendix A. 


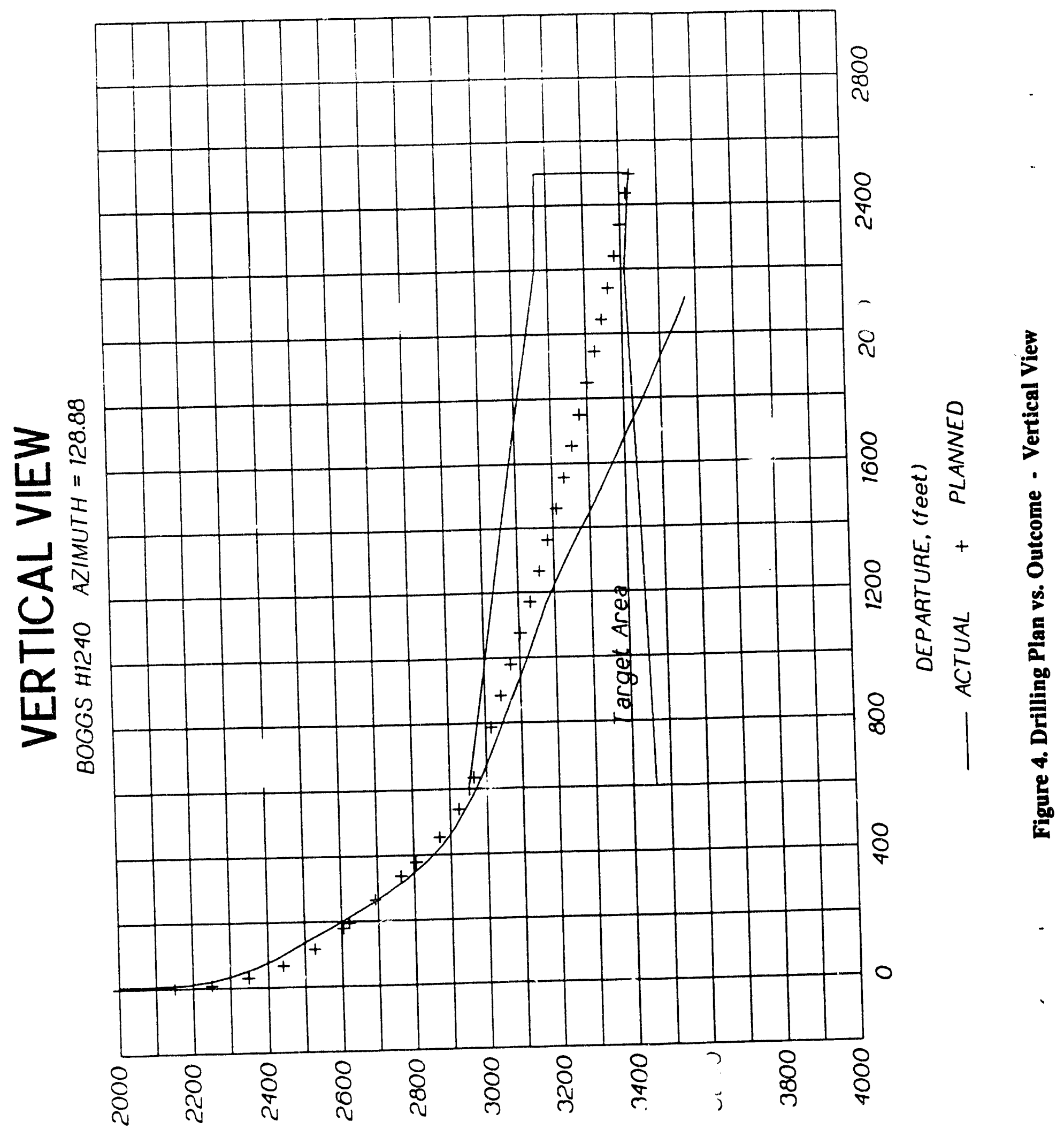

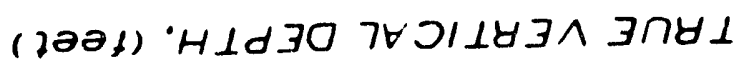




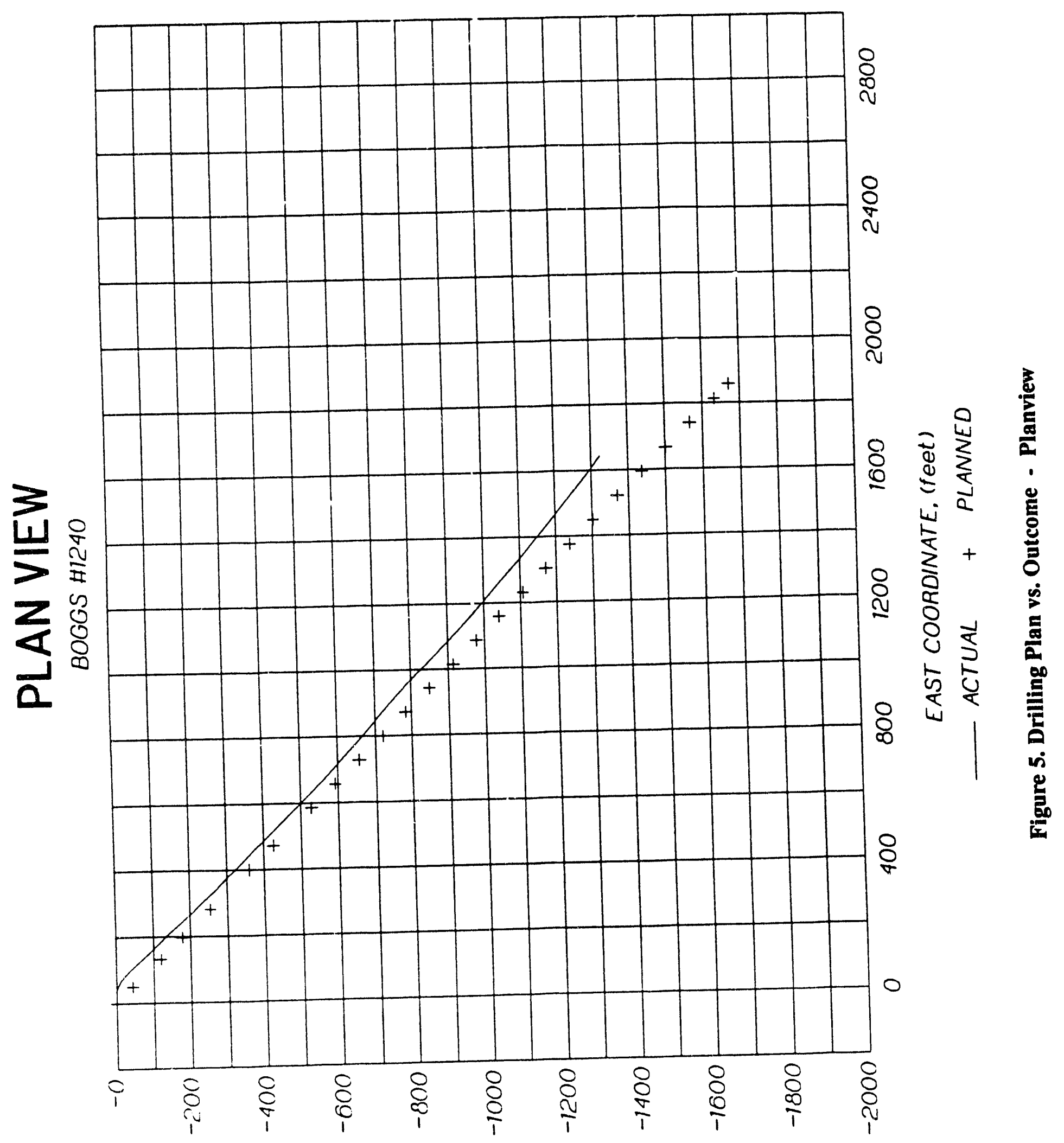

( 1ә21) $\exists 1 \forall N I O 80 O O H \perp 8 O N$ 


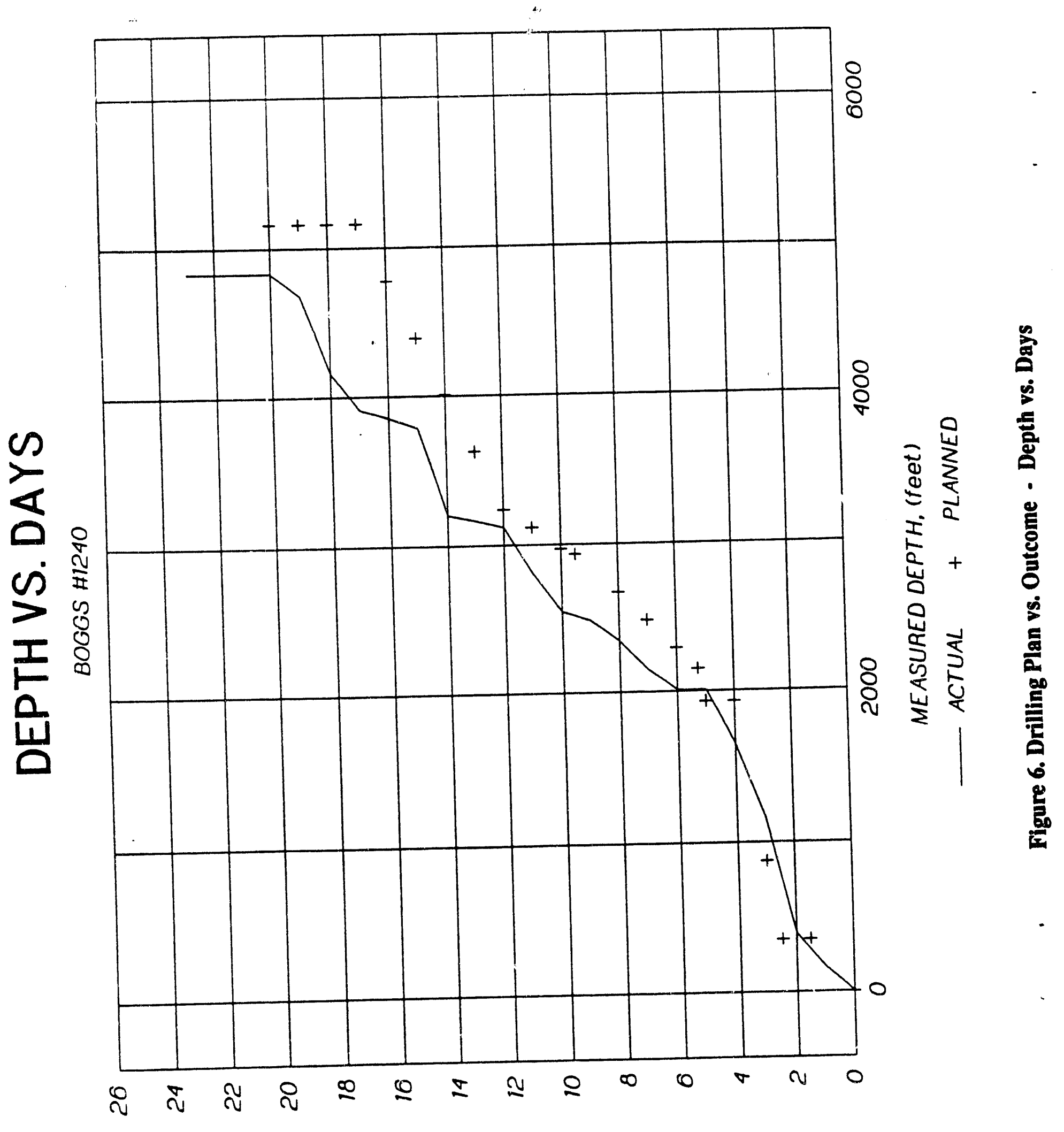

ONAS 3ONIS SALO 


\section{VERTICAL HOLE TO 2,150 FEET}

The vertical portion of the well to the KOP was drilled on a footage basis by Exeter

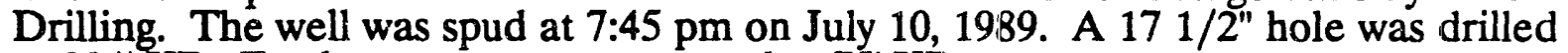
to $394^{\prime} \mathrm{KB}$. Fresh water was encountered at 75' KB.

Nine joints of $133 / 8^{\prime \prime}, 54.5$ \#/ft, ST\&C casing was run and set at 381.75' KB (371.85' GL) to isolate fresh water zones as required by the State of West Virginia. The casing was cemented to the surface as follows

Twenty barrels water with $6 \mathrm{ppb}$ gel and $2.5 \mathrm{ppb}$ celloflake, 10 barrels fresh water, 260 sacks Class " $\mathrm{A}$ " cement containing $2 \%$ calcium chloride and $1 / 8$ pps celloflake. The cement was mixed at $15.6 \mathrm{ppg}$ with a yield of $1.18 \mathrm{cubic}$ feet per sack. The cement was displaced with 59.5 barrels of water and the plug was bumped with 480 psi.

The $121 / 4^{\prime \prime}$ intermediate hole was drilled $102,010^{\prime}$ using three bits. Water was encountered and the hole was soaped after the first bit run at 1,359'.

The intermediate casing was run and set at 1,988.90' $\mathrm{KB}$ below the Big Injun. The intermediate casing was $95 / 8^{\prime \prime}, 36 \# / \mathrm{ft}$, J-55, ST\&C. The casing was cemented as follows:

Five barrels water, 20 barrels water with 6 ppb gel, 11 barrels water, 384 sacks $50 / 50$ poz containing $2 \%$ calcium chloride and $1 / 8$ pps celloflake followed by 100 sacks Class "A" cernent containirg $2 \%$ calcium chloride and $1 / 8$ pps celloflake. The $50 / 50$ poz cement was mixed at $14.2 \mathrm{ppg}$ with a yield

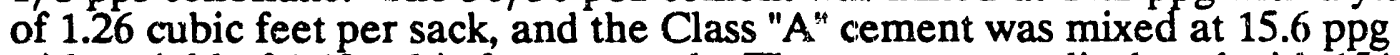
with a yield of 1.18 cubic feet per sack. The cement was displaced with 154 barrels of fresh water and the plug was bumped with 850 psi. Had good returns while cementing.

After waiting on cement twelve hours, the $133 / 8^{\prime \prime}$ calsing was cut off and welded to the $95 / 8$ " for support. The BOP's were nippled-up and the casing drilled out with an $83 / 4$ " bit to the kickoff point of 2,150 feet.

\section{ANGLE-BUILD SECTION}

At a measured depth of $2,150^{\prime}$, a directional survey was run prior to kicking the well off. The survey was $1^{\circ}, \mathrm{N} 60^{\circ} \mathrm{E}$ at a measured depth of $2,097^{\prime}$. The drilling assembly was pulled and the Eastman 8.6\%/100' motor system was run to start building inclination. The motor was oriented using the Eastman DOT tool and a side entry sub.

The first motor run was terminated at $2,362^{\prime}$ because of the slow penetration rate. The penetration rate would had varied from $30^{\prime}$ to about 3 ' per hour. The motor was drilling less than $3^{\prime}$ per hour when it was pulled. Inspection of the bit and motor indicated that there was no problem with oither. The slow penetration rates were due to changes in lithology from shale to the slower drilling siltstones. 
The Eastman Mach I motor was designed to build inclination at $8.6 \% / 100$. The actual build rate was $10.5 \% / 100^{\prime}$ which was more than the required build rate. The Baker $2^{\circ}$ bent housing motor was run to reduce the build rate to the planned rate of $8.6 \% / 100^{\prime}$. The Baker motor actuaily built inclination at a rate of $9.5 \% / 100^{\prime}$.

The penetration rate for the Baker motor was comparable to the Eastman motor $\left(9.8^{\prime} / \mathrm{hr}\right.$ and $10.6^{\prime} / \mathrm{hr}$ respectively). Because of the low penetration rates and the fact that the inclination was ahead of schedule, the tangent section was started early. Siltstone stringers were causing the low penetration $r-t e$. After the tangent section, very little siltstone stringers would be left and motor penetration rates were expected to be much higher.

The tangent section was started at 2,548' measured depth (MD). The motor-drilled hole $w$ is reamed with tie same assembly that would be used to drill the tangent section in order to avoid making an additional trip. After the directional hole was reamed, the hole was dried out and dusted to 2,811' MD. At this point, an estimated build rate of $9.5^{\circ} / 100^{\prime}$ would be needed to hit the target of $2,965^{\prime}$ true vertical depth (TVD).

Because of the price differential between the Baker motor and Eastman motor, the Baker motor was used to drill the remainder of the build section. The Baker 20 bent housing motor drilled from $2,811^{\prime}$ to $3,165^{\prime}$ at an average penetration rate of $18.2^{\prime} / \mathrm{hr}$. Only one siltstone stringer was encountered during the motor run. The motor built inclination at an average rate of $90 / 100$.

The estimated inclination at the end of the build section was $68^{\circ}$. The drilling plan had called for stopping the build section at $71^{\circ}$. However, the build rate experienced with the rotary assembly in the tangent section was $1.340 / 100$. The slant section was supposed to be built at $0.50 / 100^{\prime}$. Since the slant section was at a higher inclination in a softer formation, it was assumed that the rotary assembly would build at a lower rate; between 0.5 and $10 / 100^{\circ}$. This rate would be slightly higher than the planned rate; therefore, the slant section was started at a lower inclination to compensate for the anticipated higher build rates.

\section{SLANT SECTION}

The slant section was drilled from $3,165^{\prime}$ to a total depth of 4,833'. Basically, the rotary assembly that was used to drill the tangent section was also used to drill the slant section. On the first run, the rotary assembly drilled to a measured depth of $3,785^{\prime}$. The rotary assembly had begun io walk to the left at about $1.5 \% / 100^{\prime}$. At this rate, the wellbore would have been too close to the lease line at the end of the target interval. Since the assembly had walked to the right in the tangent section, it had been assumed that it would wall- the same in the slant section. Therefore, no right hand lead had been set at the end of the build section.

The Baker $2^{\circ}$ bent housing motor was used to turn the wellbore back to the right with the tool face set $70^{\circ}$ to the right of high side. After drilling only $70^{\prime}$ (to $3,855^{\prime}$ ), the steering tool indicated that the motor was not only turning the wellbore to the 
right but it was also dropping inclination rapidly. The motor was pulled to prevent the wellbore from dropping too much inclination.

The exact reason the motor assembly dropped inclination is not known. Initially, the key in the mule shoe sub was thought to have been knocked out with the steering tool. When trying to seat the steering tool, it continually stopped at the top of the drill collars (change in internal diameter). To overcome the problem, the steering tool was run at a higher velocity than normal. Later inspection of the mule shoe sub in the daylight showed that there was no damage to the key. The tool was also seated properly because the weight indicator showed that the latch in assembly pins sheared when the tool was pulled from the hole. Calibration of the steering tool after the motor run indicated the tool was still working properly. Surveys showed the motor had dropped 70 and turned $6^{\circ}$ to the right in the $70^{\prime}$ that it had drilled. Because of problems associated with hole cleaning (see Appendix G) and budget constraints, additional motor runs to bring the inclination back up were aborted.

While making the motor run, a discrepancy between the steering tool and singleshot survey data was noted. The singleshot continually had a three degree difference in hole direction due to magnetic interference. The discrepancy was noted both at the end of the build section and at the beginning of the motor run in the slant section. The steering tool is a more accurate instrument (electronic versus compass) so the singleshot data was adjusted three degrees. The first survey to be corrected was at a measured depth of 3,187 . All subsequent singleshot data was corrected.

After the motor run, the motor-drilled hole was reamed with a rotating bottomhole assembly. One day was spent circulating to clean the hole and drying out the hole before drilling continued to total depth (TD).

The lower inclination experienced after the motor run caused the wellbore to drop out of the target zone earlier than had been planned. The wellbore dropped below a TVD of $3,400^{\prime}$ at approximately $4,400^{\prime} \mathrm{MD}$. Drilling continued until no more shows were encountered. The last mud log show was at 4,674' MD. Total measured depth was 4,833'. The coordinates at TD are 3,570.90' TVD; 1,325.35' S; and 1643.47' E.

After logging, 113 joints of $51 / 2^{\prime \prime}, 17 \# / \mathrm{ft}, \mathrm{N}-80$, LT\&C casing was run and set at $4787^{\prime} \mathrm{KB}$. A total of 60 rigid centralizers (manufactured by Gemeco) were run with a spacing of one centralizer per joint. The top centralizer was at 2,316'. A latch down collar was placed in the top of the first joint. The $51 / 2^{\prime \prime}$ casing was cemented as follows:

Two barrels water; 40 barrels water with 3 ppb gel; 5 barrels water; 20 barrels CW-100; 10 barrels water; 605 sacks $50 / 50$ poz with $2 \%$ calcium chloride, $10 \%$ salt, 10 pps kolite, $1 \% \mathrm{D}-60,0.25 \% \mathrm{D}-46$, and $1 / 8 \mathrm{pps}$ celloflake. Cement was mixed at $13.8 \mathrm{ppg}$ with a yield of 1.46 cubic feet per sack. The cement was displaced with 112 barrels fresh water. The plug was bumped with 1,380 psi and the float held $\mathrm{OK}$.

The drilling rig was then rigged down and moved out. The casing tally can be found in Appendix B. 


\section{LOGGING}

Logging runs were attempted using conventional wireline techniques. The first log attempted was with a TV camera by Young Wireline. The TV camera fell to a depth of 1,630' where it stopped on a ledge on the low side of the hole.

Schlumberger was rigged up and made several logging runs with conventional logging techniques; none of which made it to TD. The logging runs and depth reached are as follows in Table 1.

Table 1. Logs and Logged Intervals - Conventional Logging

LOG RUN \# LOGS DEPTH LOGGED

i Temp, LDT, NGT

2 Same as \#1 with extra weight

3 Same as \#2 with teflon guides

4

Induction $\log$

SNP with rubber nose guide $3131^{\prime}$

$3154^{\prime}$

$3078^{\prime}$

$3210^{\prime}$

$3138^{\prime}$

Schiumberger then rigged up their TLC (Tough Logging Conditions) drill pipe conveyed logging system. Table 2 lists the logs run and intervals logged with the TLC equipment.

Table 2. Drill Pipe - Conveyed Logs and Logged Intervals

LOG RUN \#

6

7
LOGS

LDT, NGT, Induction

Temp, and SNP
DEPTH LOGGED

$4833^{\prime}$

$4833^{\prime}$

After running Schlumberger's TLC equipment, Young Wireline was rigged up and a TV camera was run from 2,847' to 4,833' using drill pipe and a side entry sub. The drill pipe taliies for each logging run can be found in Appendix C.

\section{COMPLETION AND STIMULATION}

Four inter'als were selected for completion and stimulation based on mud log shows and anaiysis of the aforementioned $\log$ suite. Based upon pre-stimulation 
data, the best of the shows were well below the bottom of the target zone as presented in Figure 4. Offset well data had suggested that the best zone(s) should be expected near the top of the target zone. Moreover, the deeper zones were not even encountered in the offset vertical wells. These factors combined suggest the targeted fracture system to be more complex than interpretations of vertical well control had predicted.

Four separate hydraulic fracturing treatments were performed. Stimulation treatments are summarized by completion stage in Table 3 . In Figure 7, principle gas show intervals are bounded, top and bottom, with X-symbols plotted directly on the wellbore trajectory. Completion stages are indicated by numbered subhorizontal bars above the wellbore trajectory. Completion stage numbers in Figure 7 correspond to those in Table 3.

Table 3. Summary of Stimulation Treatments

\begin{tabular}{|c|c|c|c|c|}
\hline Stage & $\begin{array}{l}\text { Perforated } \\
\text { Interval (MD) }\end{array}$ & Length & $\begin{array}{l}\text { Nitrogen } \\
\text { Volume }\end{array}$ & $\begin{array}{l}\text { Flow } \\
\text { Rate }\end{array}$ \\
\hline 1 & $4,618^{\prime}-4,6,24^{\prime}$ & $6^{\prime}$ & 1,303 MCF & 30-35 MCF/D \\
\hline 2 & $4,416^{\prime}-4,563^{\prime}$ & $147^{\prime}$ & $1,465 \mathrm{MCF}$ & 45-54 MCF/D \\
\hline 3 & $4,144^{\prime}-4,356^{\prime}$ & $212^{\prime}$ & $1,170 \mathrm{MCF}$ & 40-45 MCF/D \\
\hline 4 & $3,466^{\prime}-4,, 036^{\prime}$ & $570^{\prime}$ & $1,800 \mathrm{MCF}$ & $80 \mathrm{MCF} / \mathrm{D}$ \\
\hline
\end{tabular}

The stimulated intervals ranged from 6 to 570 feet long. All intervals were treated with straight nitrogen, as were the vertical wells in the field. Nitrogen volumes ranged from $1,170,000$ to $1,800,000$ standard cubic feet, with injection rates ranging from 70,000 to 80,000 standard cubic feet per minute. Each zone was broken down ahead of the nitrogen with 400 to 500 gallons of $7.5 \%$ acid. Individual intervals were isolated with a retrievable bridge plug. Perforating was performed via wirelineconveyed hollow carrier guns using a set of specially designed rollers.

Production for each stage was measured after the nitrogen volume had dropped below $10 \%$. Measurements were made through an orifice runaway and back pressure regulator to simulate line pressures of 40 to 45 psig. Flow rates (see Table 3) were monitored against simulated line pressure for several weeks in order to establish stabilized flow rates for each zone. Stabilized flow rates for the four zones summed to a total of $195 \mathrm{MCF} / \mathrm{D}$ but were not sustainable at that level under producing conditions. Much shorter duration measurements, meant to approximate open flows as measured at offset wells, summed to a total of $1.4 \mathrm{MMCF} / \mathrm{D}$ for the four zones. Both measurements suggested an apparent three-fold improvement over the average vertical well in the area.

\section{RESERVOIR PROPERTIES}

Testing of reservoir properties was limited to the six-foot interval completed in stage 1. Prior to the 1,303 MCF nitrogen frac listed in Table 3, completion stage number 1 


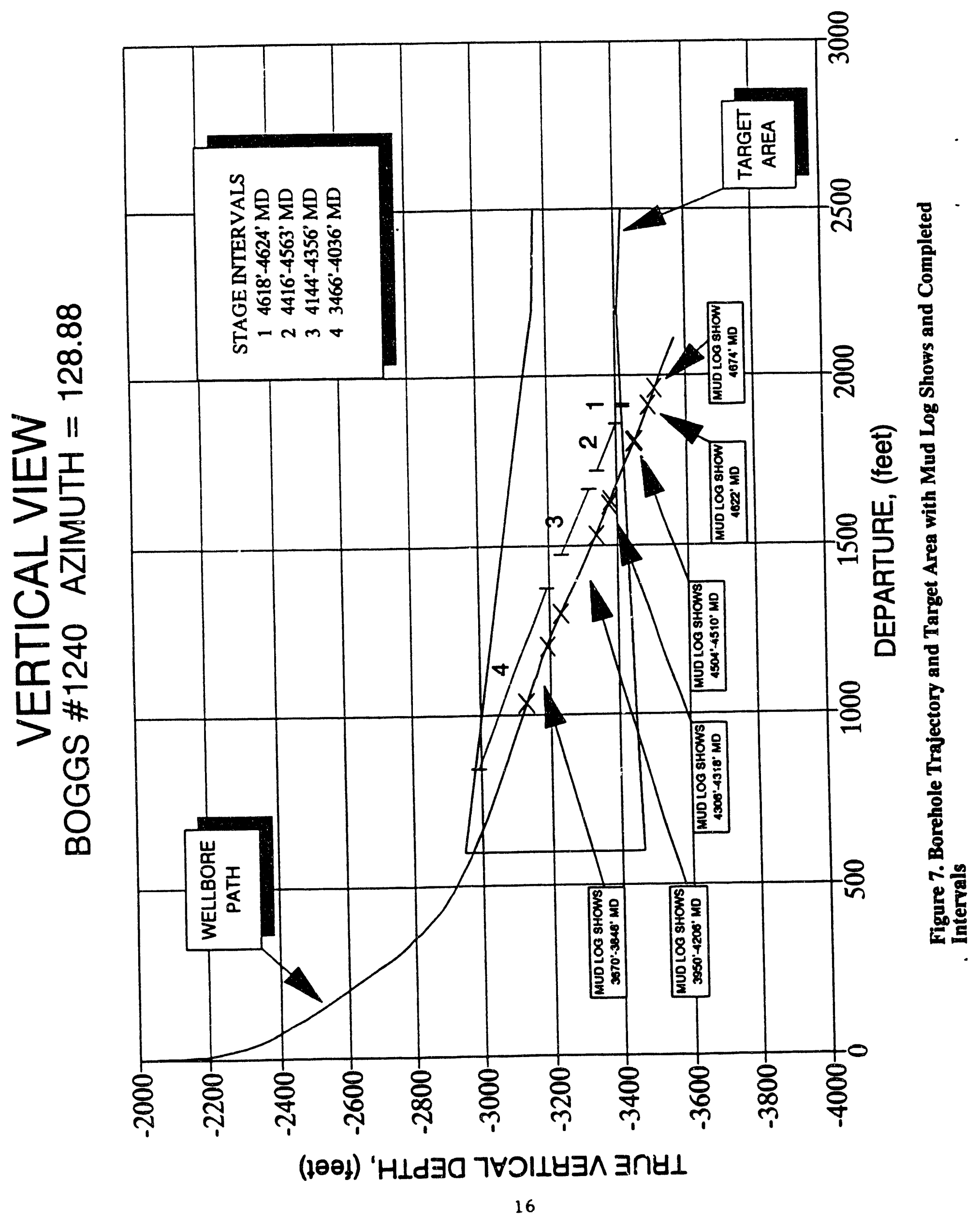


received 500 gallons of $7.5 \% \mathrm{HCl}$ acid and, unlike stages 2 through 4 , also received a $386 \mathrm{MCF}$ nitrogen breakdown treatment. Testing of reservoir properties by Reuben Graham, Inc. (GRI) began immediately after breakdown with a series of flow/shut-in periods. Results of the final flow period indicated the six-foot perforated interval was able to deliver between 8 and $9 \mathrm{MCF} / \mathrm{D}$; and approximately $0.5 \mathrm{BBL}$ of oil was swabbed each day.

Following the last flow period, a 358.4-hour pressure build-up test was performed. Analysis of this pressure build-up test by S.H. Holdich \& Associates, via conventional type-curve and semi-log "Horner" analysis, found a permiabilitythickness product (kh) of only 0.2 md-ft. Assuming a net pay of $26 \mathrm{feet}$, an average post-breakdown permiability of $0.0076 \mathrm{md}$ and an apparent skin factor of -2.1 were calculated; and an initial reservoir pressure of 981 psia was estimated. Assuming a net pay of 5 feet, however, suggests a permiability of $0.04 \mathrm{md}$ and a skin factor of -2.8 . Based on these results, it was concluded that the zone was stimulated by the 386 MCF breakdown treatment, but that the breakdown treatment failed to connect the borehole with any significant natural fracture system (Graham, 1991). S.H. Holdich's analysis of reservoir properties can be found in Appendix I.

\section{PRODUCTION}

Production history and projections for the Glada Boggs 1240 are presented in Figure 8. Thus far, gas deliverability has been far lower than had been expected. Unexpected oil production of approximately 1 barrel per day has had a substantial detrimental effect on gas deliverability. Operational aspects of gas production have been complicated, and gas deliverability reduced, by the periodic buildup of hydrostatic pressure due to accumulation of oil in the wellbore. Moreover, gas flow into the wellbore may be significantly curtailed due to relative permiability of the reservoir rock to oil and gas.

Initially, both gas and oil were produced through the well's production tubing string Typically, the well was taken off-line about once per month, and the gas vented to the atmosphere to clear the tubing of accumulated oil. Under these operating conditions, gas production ranged from a high on the order of $60 \mathrm{MCF} / \mathrm{D}$ to lows on the order of $10 \mathrm{MCF} / \mathrm{D}$ with average gas and oil production of approximately 15 to $16 \mathrm{MCF} / \mathrm{D}$ and $0.95 \mathrm{BBL} / \mathrm{D}$ respectively. Problems with this operating mode were (1) low average gas deliverability, and (2) loss of gas vented to the atmosphere.

Initial indications were that incremental production increases from an artificial lift system probably would not support incremental expenses. Instead, in July 1991, it was decided to produce gas through the casing with periodic swabbing of oil through the tubing. This mode of operation would permit more continuous production of gas, prevent loss of gas to the atmosphere, and it was hoped, would raise average gas and oil production rates by reducing the average hydrostatic pressure on the reservoir. Insufficient production data has been compiled to test this hypothesis completely. However, preliminary indications are that gas production has increased by more than $20 \%$ to an average of 19 to $20 \mathrm{MCF} / \mathrm{D}$. A similar increase has not been seen in oil production which has remained at about $1 \mathrm{BBL} / \mathrm{D}$. This increase in gas deliverability is the justification for shifting the gas projection up as shown in Figure 8. 


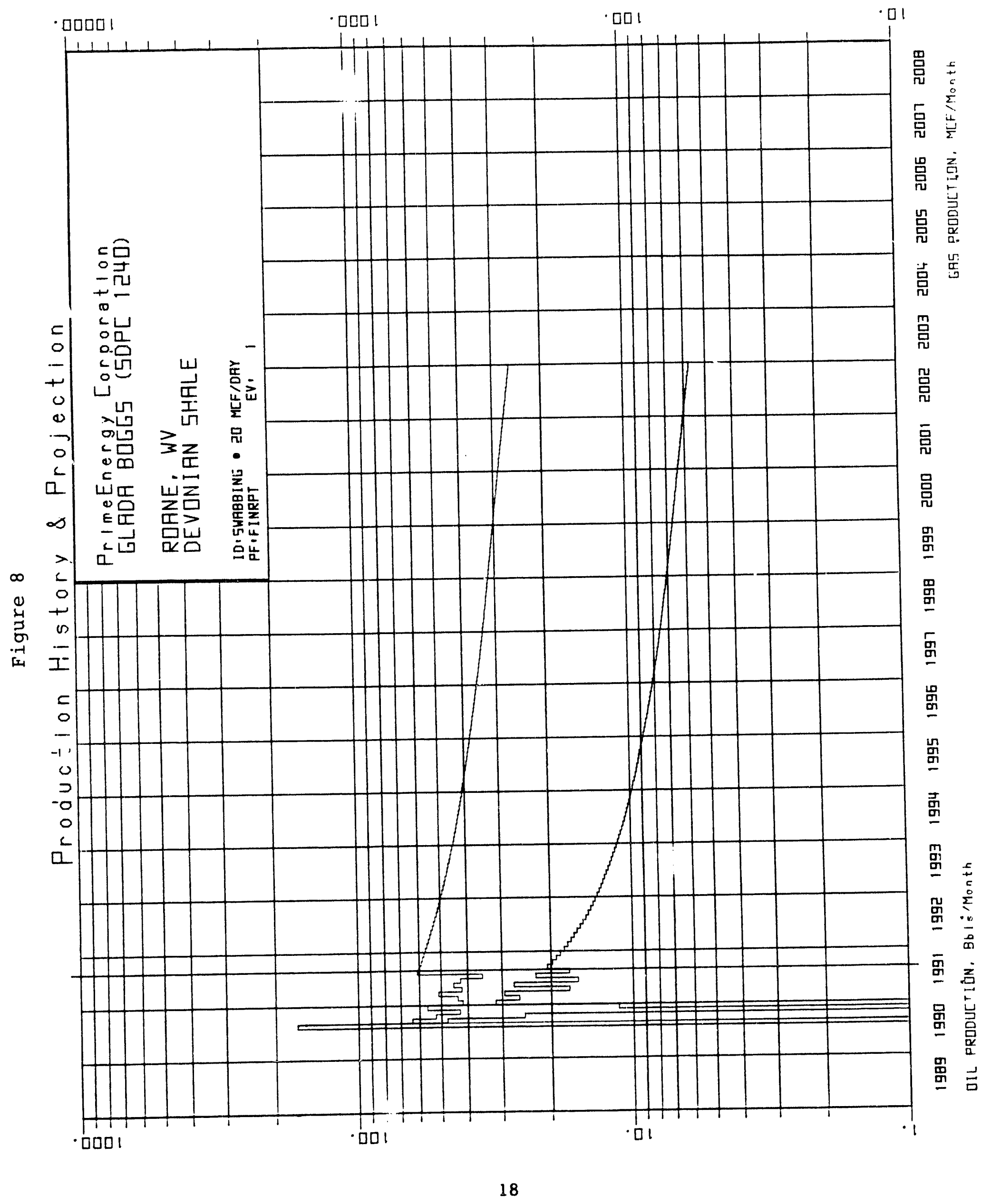


Cumulative production for the period September 1990 through August 1991 totalled $5,750,000$ cubic feet of gas and 493 barrels of oil. In contrast, production of nearoffset vertical wells ranged from $5,200,000$ to $53,500,000$ cubic feet of gas, and no oil, during an equivalent 12-month period. Oil production is thought to be coming from the zone at 4,622 feet measured depth, completed in stage 1; a zone which apparently was not encountered in any of the near-offset vertical wells.

Production data compiled to date suggests that sustained gas deliverability on the order of $60 \mathrm{MCF} / \mathrm{D}$ may be possible if problems associated with low-volume oil production could be solved. Future operations work will explore the possibility of squeezing-off the deeper completion in hopes of realizing this potential.

\section{PROJECT COST}

The total actual cost of the Glada Boggs 1240 well is $\$ 726,123$. The total projected cost per the project AFE was $\$ 655,666$. This gives a total variance for the project of $(\$ 70,457)$ or $(10.75 \%)$; very close to the AFE cost for a well of this type. A.ctual and AFE costs and variances are presented on a line-item basis in Figure 9.

\section{PROJECT ECONOMICS}

A histogram of ultimate recoverable reserves for 36 vertical wells offsetting the Boggs 1240 is presented in Figure 10. On the horizontal axis is projected ultimate recovery in MMCF. On the vertical axis is the number of wells in each of the reserves categories. Reserves were estimated via decline curve analysis of individual wells. Individual production histories were fitted and declined for a total (historical + projected) of 35 years. This differs from the statistically derived type-curve approach presented in the earlier paper (Muncey, 1989a), but has led to essentially identical conclusions regarding drilling economics.

An important insight from the revised reserves analysis is that it is now more clear that the distribution of reserves is actually bimodal. A high-reserves population and a low-reserves population are now apparent. Both populations appear to exhibit log-normality. It is also interesting to note that at least two of the three wells which make up the high-reserves population are apparently associated with the northwest structural trend which is evident in Figure 3. Assuming a log-normal distributuion, average reserves for the total population are $68 \mathrm{MMCF}$ per well. Averages for the low-reserves and high-reserves populations are $47 \mathrm{MMCF}$ and $640 \mathrm{MMCF}$ respectively.

Economic modeling presented in Figure 11 suggests that, at todays gas prices and cost structure, vertical wells with ultimate recoveries of less than about $250 \mathrm{MMCF}$ are uneconomical to drill, even with the Section-29 tax credit. Selected economic assumptions underlying the minimum economic reserves figure are listed in Table 4. The form of production decline is derived from type-curve analysis of the 36 offsetting vertical wells. Minimum reserves were estimated by iteratively scaling the initial production rate of the type-curve until the minimum rate of return $20 \%$ before Federal income tax) was converged upon. It should be noted that the minimum (vertical well) economic reserves figure has increased substantially, fromthe 150 MMCF figure used in Muncey, 1989a, to reflect current conditions in the gas market and revised price expectations arising from those conditions. 


\section{EXPENSE CATEGORY}

Casing - Prolection

Casing - Surface

Liner Hanger \& Equipment

Miscellaneous/Trucking

Well Head Equipment

Casing - Production

Heater Treater \& Separator

Installation Cost

Tank Battery

Tubing

Administrative Overhead

Directional Tool \& Service

Drilling Daywork

Drilling Footage

Engineering/Supervision (drilling

Fuel, Power \& Water

Legal \& Abstract

Location \& Road

Miscellaneous

Mud \& Chemicals

Mud Logger/Gas Protector

Permit \& Fees

Retal Equipment

Rig Mobilization \& Demobil

Supplies - Bits

Engineering Surveys \& Eleva

Wireline Serv - Open Hole

Casing Crew \& Equipment

Cement Service \& Equipment

Completion Rig

Engineering/Supervision (comple

Location - Damages

Stimulation, Frac, Acid

Wireline Serv - Cased Hole

Wireline Serv - Perforating

Total

\begin{tabular}{|c|c|c|c|c|}
\hline$A F B$ & ACTUAL & $\underset{\text { ACTUAL }}{\text { X }}$ & VARIANCE & $\stackrel{\%}{\text { VARIANCE }}$ \\
\hline $29,394.00$ & $28,431.54$ & $3.92 \%$ & $\$ 962.46$ & $3.27 \%$ \\
\hline 5,60 & $5,640.50$ & $0.78 \%$ & $(\$ 40.50)$ & $(0.72 \%)$ \\
\hline 5,00 & 0.00 & $0.00 \%$ & $\$ 5,000.00$ & $100.00 \%$ \\
\hline $1,000.00$ & 0.00 & $0.00 \%$ & $\$ 1,000.00$ & $100.00 \%$ \\
\hline $5,000.00$ & 828.59 & $0.53 \%$ & $\$ 1,171.41$ & $23.43 \%$ \\
\hline $36,360.00$ & $46,355.24$ & $6.38 \%$ & $(\$ 9,995.24)$ & $(27.49 \%)$ \\
\hline $3,225.00$ & $6,210.26$ & $0.86 \%$ & $(\$ 2,985.26)$ & (92.57\%) \\
\hline $2,000.00$ & $7,032.00$ & $0.97 \%$ & $(\$ 5,032.00)$ & (251.60\%) \\
\hline $4,500.00$ & 868.38 & $0.12 \%$ & $\$ 3,631.62$ & $80.70 \%$ \\
\hline $18,060.00$ & $22,272.90$ & $3.07 \%$ & $(\$ 4,212.90)$ & (23.33\%) \\
\hline 12,8 & $17,505,50$ & $2.41 \%$ & $(\$ 4,648.50)$ & $(36.16 \%)$ \\
\hline $110,000.00$ & 81,98937 & $11.29 \%$ & $\$ 28,010.63$ & $25.46 \%$ \\
\hline $60,000.00$ & $58,968.75$ & $8.12 \%$ & $\$ 1,031.25$ & $1.72 \%$ \\
\hline $29,670.00$ & $26,108.00$ & $3.60 \%$ & $\$ 3,562.00$ & $12.01 \%$ \\
\hline $10,000.00$ & $29,909.41$ & $4.12 \%$ & $(\$ 19,909.41)$ & (199.09\%) \\
\hline $7,500.00$ & $5,520.00$ & $0.76 \%$ & $\$ 1,980.00$ & $26.40 \%$ \\
\hline $2,000.00$ & $2,752.00$ & $0.38 \%$ & $(\$ 752.00)$ & $(37.60 \%)$ \\
\hline $21,000.00$ & $20,794.36$ & $2.86 \%$ & $\$ 205.64$ & $0.98 \%$ \\
\hline $5,000.00$ & $3,754.79$ & $0.52 \%$ & $\$ 1,245.21$ & $24.90 \%$ \\
\hline $10,000.00$ & $16,257.06$ & $224 \%$ & $(\$ 6,257.06)$ & $(62.57 \%)$ \\
\hline $10,000.00$ & $9,644.00$ & $1.33 \%$ & $\$ 356.00$ & $3.56 \%$ \\
\hline 450.00 & 985.00 & $0.14 \%$ & $(\$ 535.00)$ & (118.89\%) \\
\hline $10,000.00$ & 220.00 & $0.03 \%$ & $\$ 9,780.00$ & $97.80 \%$ \\
\hline $4,200.00$ & 773.50 & $0.66 \%$ & $(\$ 573.50)$ & (13.65\%) \\
\hline $16,000.00$ & $19,942.36$ & $2.75 \%$ & $(\$ 3,942.36)$ & $(24.64 \%)$ \\
\hline $1,500.00$ & 0.00 & $0.00 \%$ & $\$ 1,500.00$ & $100.00 \%$ \\
\hline $38,500.00$ & $62,862.98$ & $8.66 \%$ & $(\$ 24,362.98)$ & (63.28\%) \\
\hline $2,000.00$ & $1,202.00$ & $0.17 \%$ & $\$ 798.00$ & $39.90 \%$ \\
\hline $25,000.00$ & $32,545.87$ & $4.48 \%$ & $(\$ 7,546)$ & $(30.18 \%)$ \\
\hline $24,000.00$ & $41,360.47$ & $5.70 \%$ & $(\$ 17,360.47)$ & (72.34\%) \\
\hline $25,000.00$ & $50,898.41$ & $7.01 \%$ & $(\$ 25,898.41)$ & (103.59\%) \\
\hline $10,850.00$ & $7,821.74$ & $1.08 \%$ & $\$ 3,028.26$ & $27.91 \%$ \\
\hline $90,000.00$ & $99,333.79$ & $13.68 \%$ & $(\$ 9,333.79)$ & (10.37\%) \\
\hline $10,000.00$ & $3,100.01$ & $0.43 \%$ & $56,899.99$ & $69.00 \%$ \\
\hline $10,000.00$ & $7,234.50$ & $1.00 \%$ & $\$ 2,765.50$ & $27.66 \%$ \\
\hline & & & & \\
\hline
\end{tabular}

Figure 9. Project Cost - AFE vs. Actual 


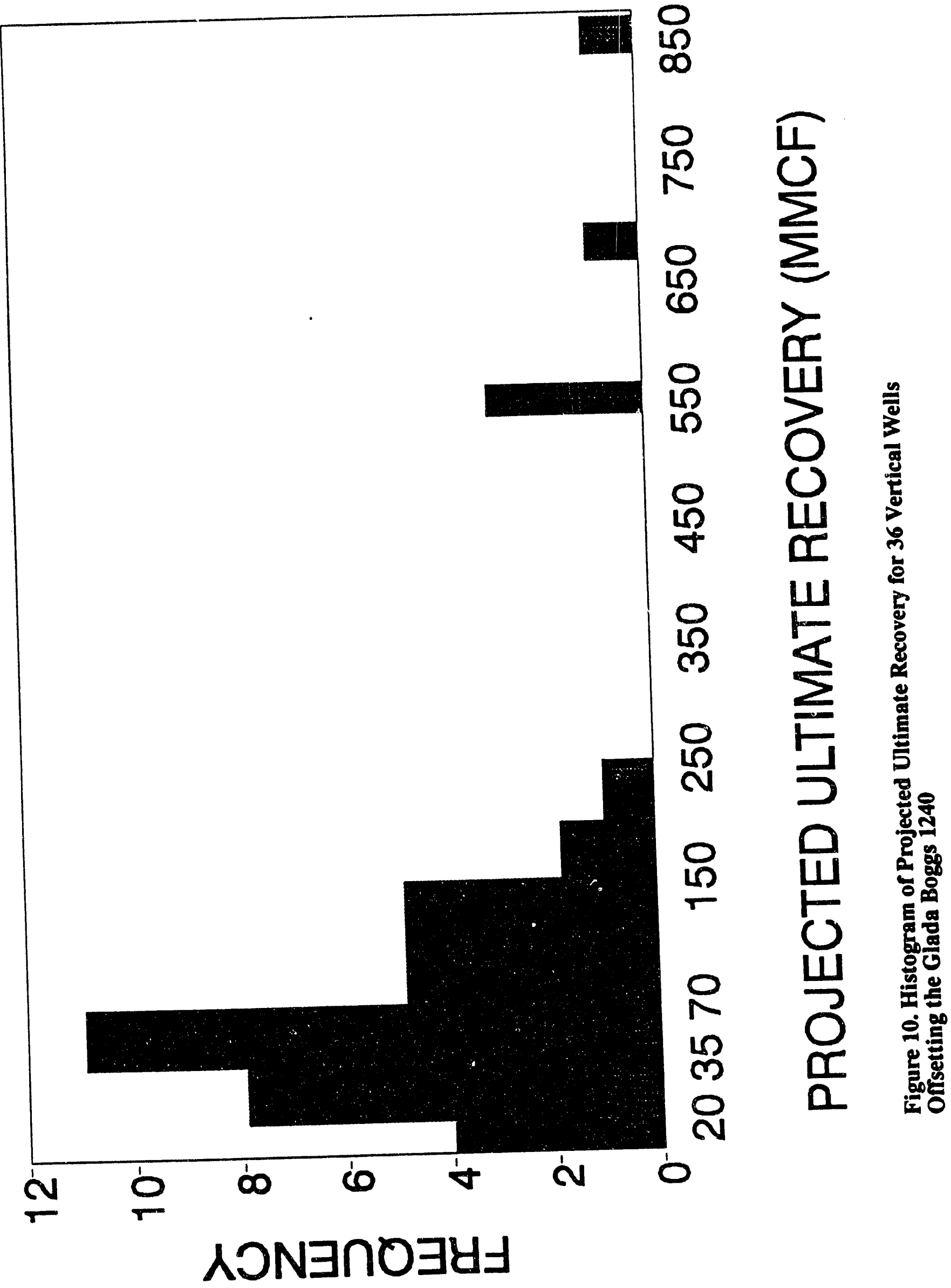



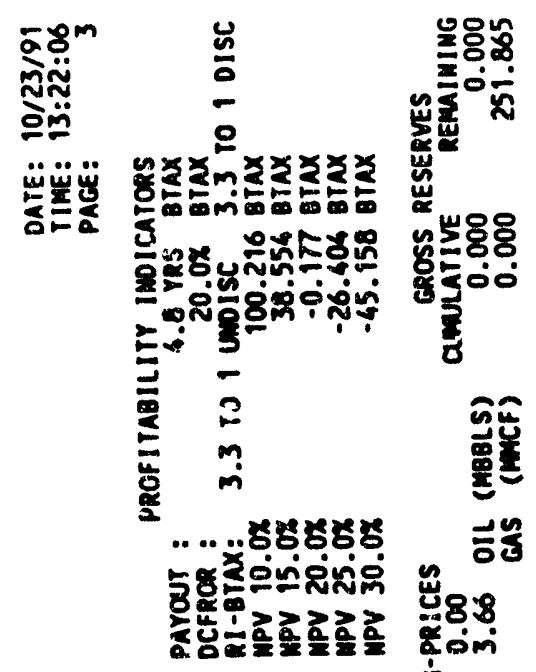

的骂

客

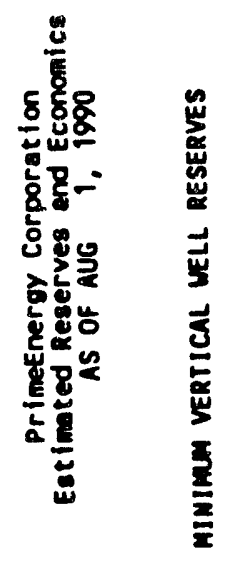

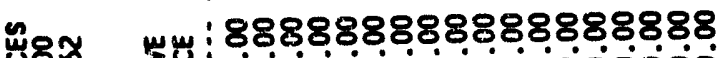

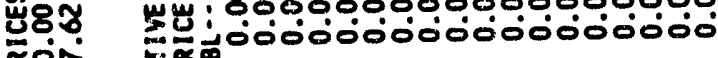
天ån

害

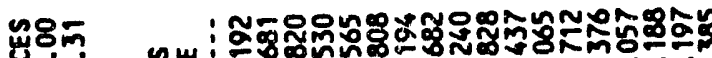

这

这绻

t:ํ:

8

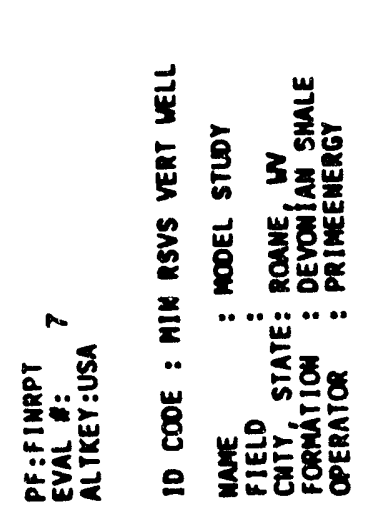

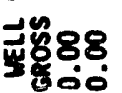

莍

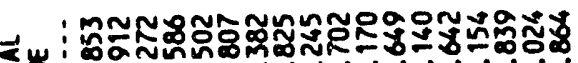
อ. 部

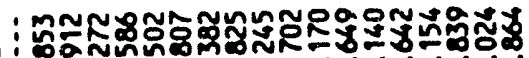

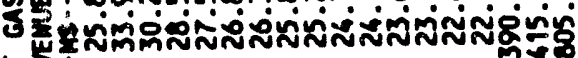
㟧

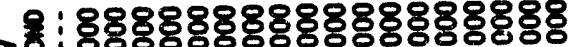
+ 颣:

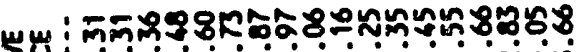

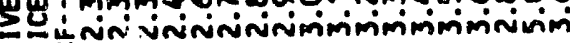
包然

部敬

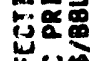

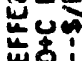

3) 站

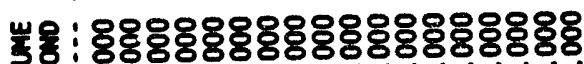

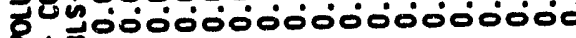
퐁ํำ

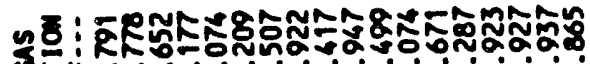
) 迢:

88 : 8888 8 迢:

(n) 0000000000000000000000

8

茟芯

惫

8
5
5
8
8

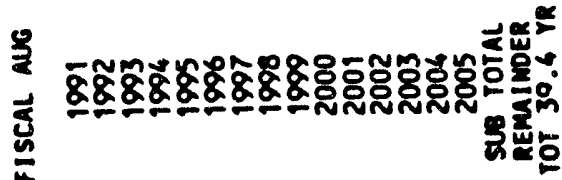

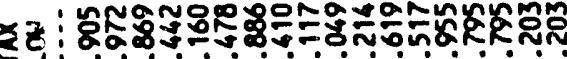

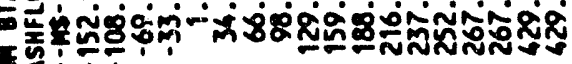
ชठ

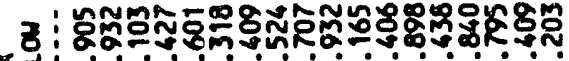
3. S!

流

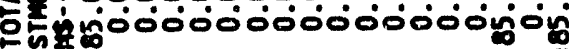
整

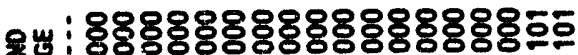

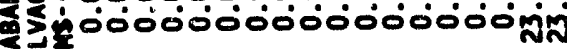
端:

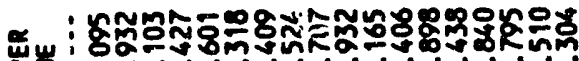
8. 率:

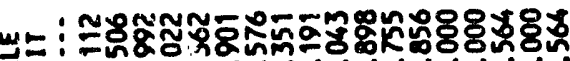
预 站:

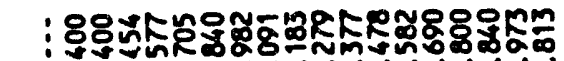

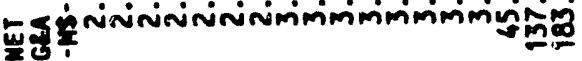

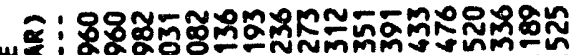
>

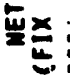

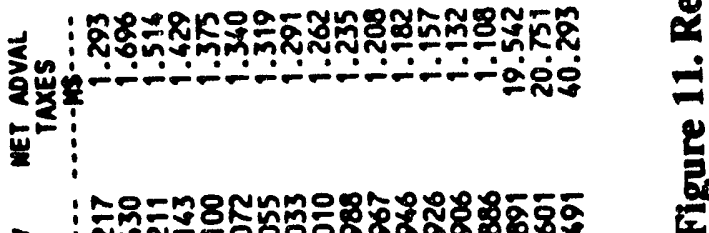
Uै ب. 整

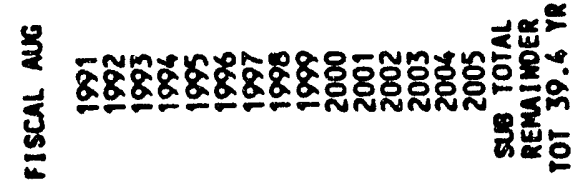


The most important thing to note in Figure 10, however, is that the success rate implied by the sample population is very low; only on the order of $10 \%$. We can conclude from this that the width and spacing of the fractured zones which characterize the reservoir are such that they make extremely risky targets for conventional vertically-drilled wells.

Figure 12 presents economics of the minimum acceptable slant well. Net revenue interest, operating cost, gas price, tax and discount rate assumptions are identical to those presented in Table 4. A non-research completed well cost of $\$ 500,000$ is assumed. The form of production decline is identical to the projection in Figure 8 . Again, minimum reserves were estimated by iteratively scaling the initial production rate until the minimum rate of return was converged upon.

The results presented in Figure 12 suggest that, in this particular project area, slant wells would have to produce approximately $635 \mathrm{MMCF}$ of gas on average, or roughly 9 times the $68 \mathrm{MMCF}$ reserve average for our 36-well population, to constitute an economically viable investment. This means that the mean value of a slant well reserves distribution would have to be roughly 9 times that of the distribution illustrated in Figure 10.

\section{Table 4. Selected Economic Assumptions}

Gas Price

Operating Expenses

Net Revenue Interest

Taxes

Discount Rate

Well Cost
$\$ 2.31 / \mathrm{MCF}$; Flat prices for 2 years, Escalated@5\% per year for 5 years, $3 \%$ per year thereafter

$\$ 280$ Per Month; Flat for 2 years, Escalated@ @ $5 \%$ per year for 5 years, $3 \%$ per year thereafter

\section{$87.5 \%$}

Economics are before Federal Income Tax

Tax Credit Per Section 29 oi U.S. Tax Code treated as element of operating income

Minumum acceptable pre-tax return $=20 \%$

$\$ 185,000$ Through Completion

Projected economics and reserves for the Glada Boggs 1240 are presented in Figure 13. Oil and gas production history and projections are illustrated in Figure 8. This economic evaluation differs from the minimum vertical and slant well evaluations in that the well produces oil. Oil prices are assumed constant for two years, then are escalated at $5 \%$ per year for five years; then $3 \%$ thereafter. All other assumtions are identical to those outlined in Table 4. Given the economic assumtions, the Glada Boggs well is projected to cum 1,706 BBLS of oil and $58 \mathrm{MMCF}$ of gas over a projected economic life of 13 years. The well will never payout, and the estimated net present value at the assumed pre-tax discount rate of $20 \%$ is about $-\$ 424,000$. 
ํㅗㄹ용

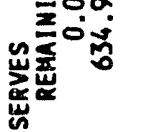

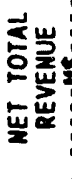

닝응

. 寒

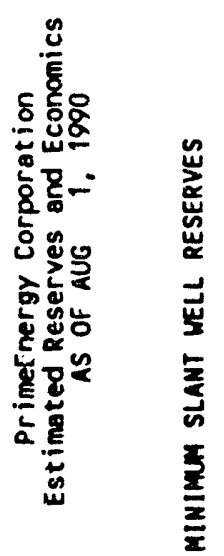

जิ

壎

프ㅇㅝㅝ

歖

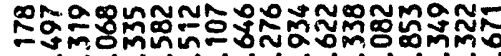

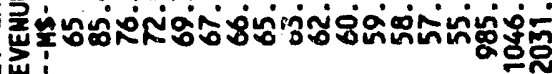

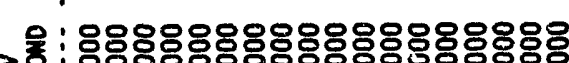

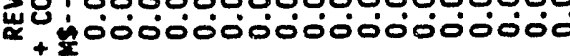
플

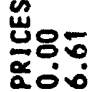

安

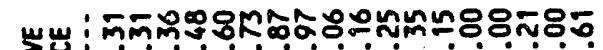

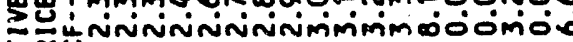

悹容

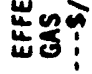

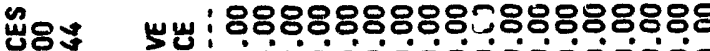

Win इัom

䇋

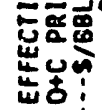

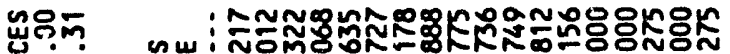

क्ष

㟧现 플

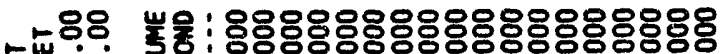

武融

\$+口000000000000000000

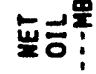

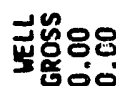

00

然

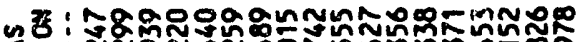

o

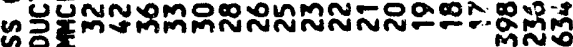
สำ

8율 :

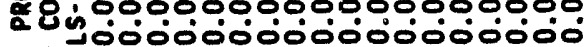

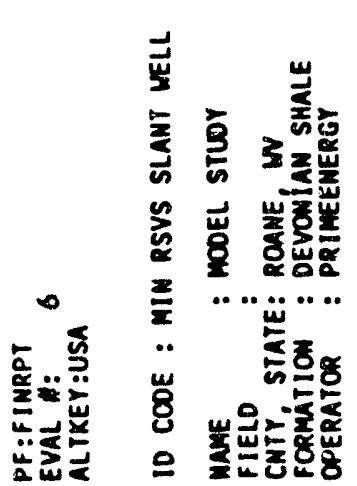

兽

通司!

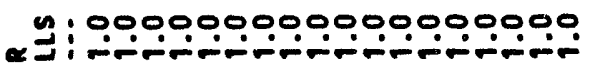

禀

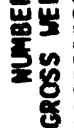

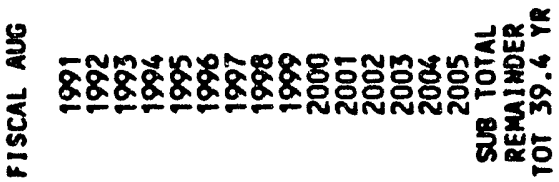

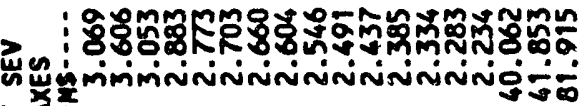

ใ군

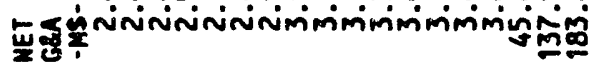

ㄴ

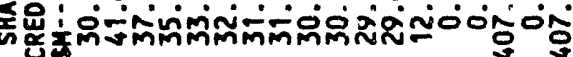
部希

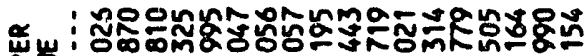

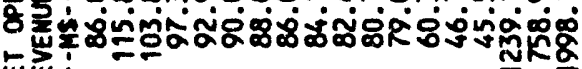
岸

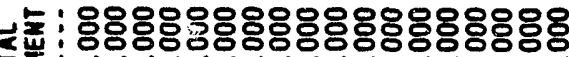

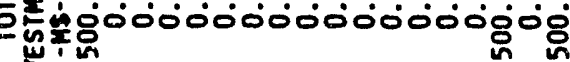
焉空!

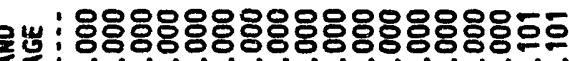
\%彳 苾品

ล

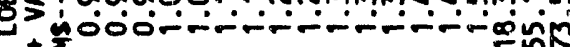
产希

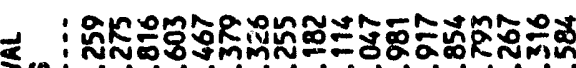
aิ $\overline{\mathrm{w}}^{-}$ 龂

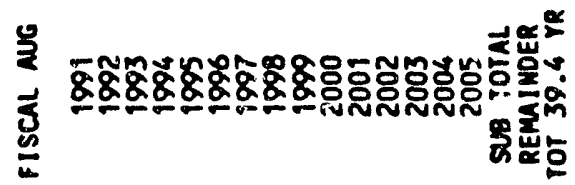




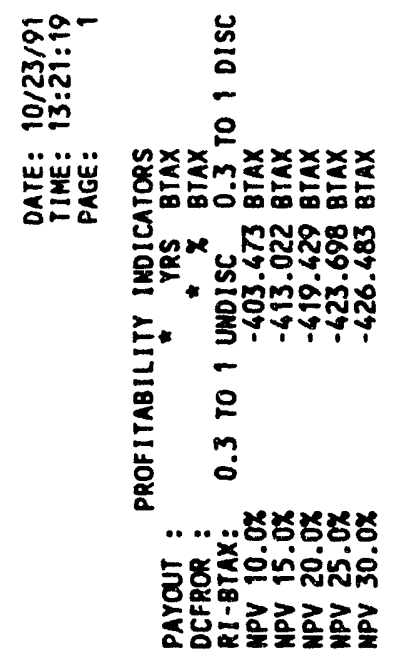

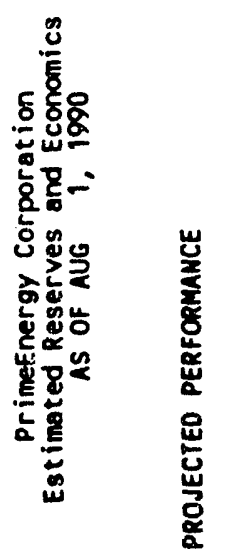

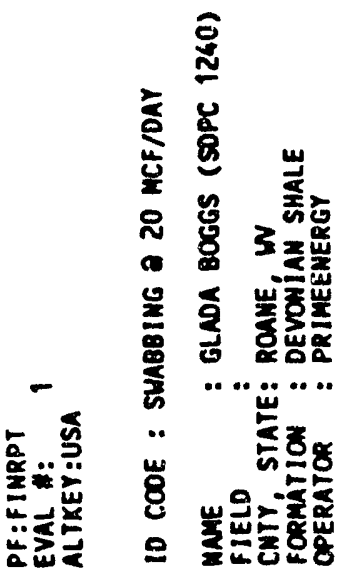

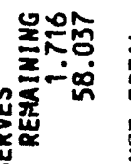

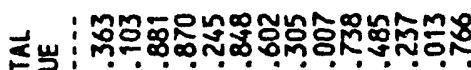

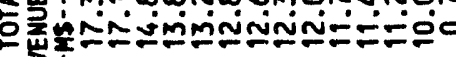
娄

4 ㄴㅇㅇ응 ¿ 氖

㩊

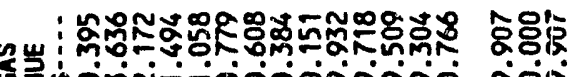
oิ 羟:

要

ㅇำ:

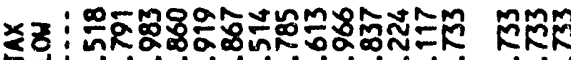
表崖

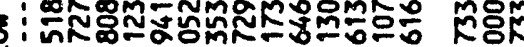

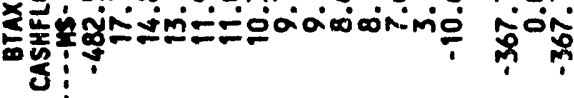

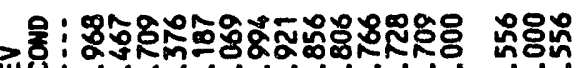

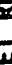

㟧

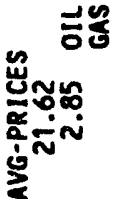
崖:

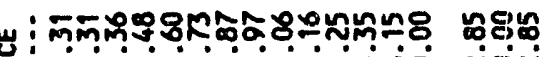

iuninininininimimimimio viein

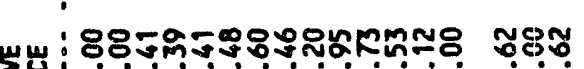

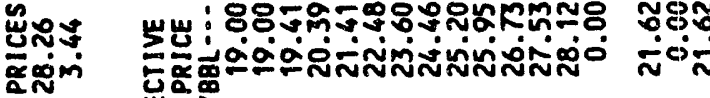

妾 部

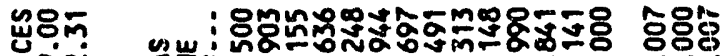
åin 幽绻 政 gog

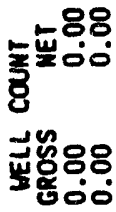

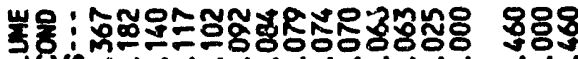

乌. क्ष000000000000000 -0. 플ㅎํ:

oc

过

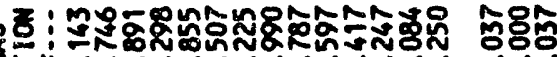

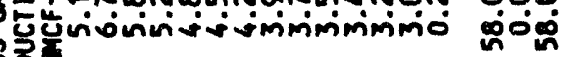
茶

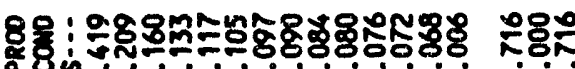

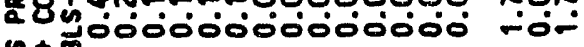

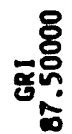
क्षे

0000000000000000000

)

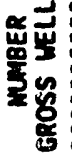

윰

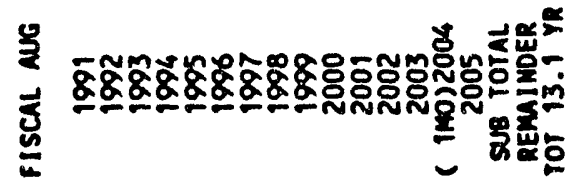

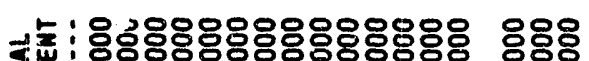
装츤

우

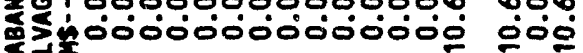
ज्ञा?

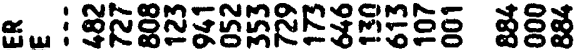

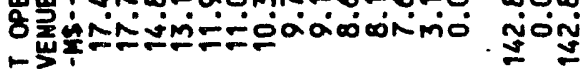
韾:

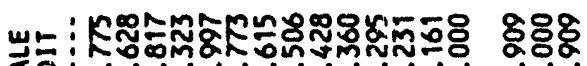

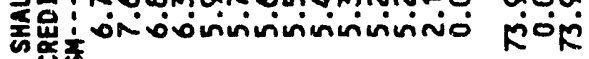
突希:

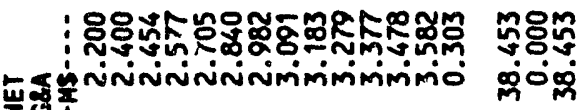

ลิ

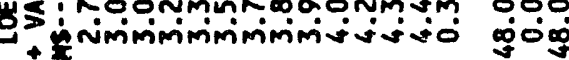
要爻:

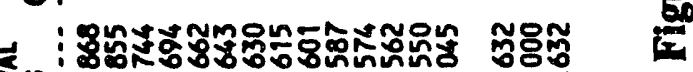
崖:

บ

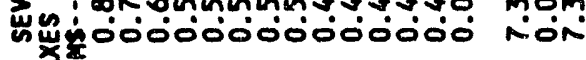
뜬?

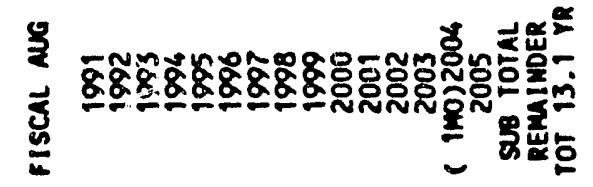

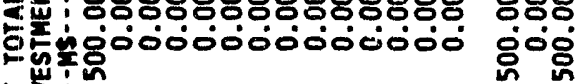

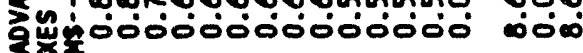




\section{SUMMARY AND CONCLUSIONS}

This paper presents the final results of a directionally-drilled Devonian Shale well in Roane County, West Virginia. Drilling operations resulted in a wellbore which meets virtually all design criteria. Funds budgeted for the project totaled $\$ 655,666$. Total funds expended for the project are approximately $\$ 726,123$; a budget variance of $(10.75 \%)$. Based on the above it is clear that the project has successfully demonstrated the technological feasibility of slant well drilling and must, therefore, be considered an engineering success.

Unfortunately, the project well cannot be considered an economic success, nor can it be considered a geological success. Lower-than-expected gas deliverability suggests that neither the high-angle drilling nor subsequent hydraulic fracturing treatments were successful at connecting the borehole with the natural fracture system(s) encountered in nearby high-deliverability vertical wells. This, combined with a borehole which met virtually all of its design criteria, suggests that the vertical-well-based reservoir model failed to adequately predict fracture distribution within the reservoir. Furthermore, the apparent absence of fractures predicted by the vertical-well-based reservoir model suggests that Devonian Shale fracture systems, at least in the study area, may not exhibit sufficient continuity along strike and depth for directional drilling to deliver an economic benefit.

Analysis of production histories of 36 nearby vertical wells suggests that the average vertical well in the project area will ultimately produce only about $68 \mathrm{MMCF}$ of gas. Economic modeling has shown that, on average, slant wells in the area would have to recover $635 \mathrm{MMCF}$, or about 9 times the gas reserves of the average vertical well in the area, for such drilling to be considered economically viable.

Analysis of one year of production history suggests that, under current mode of operation, the project well will produce only about $85 \%$ as much gas as the average vertical well in the study area. However, the production data also suggest that sustained gas deliverability could be increased by roughly a factor of three (from 20 $\mathrm{MCF} / \mathrm{D}$ to $60 \mathrm{MCF} / \mathrm{D})$ if operational problems associated with low-volume oil production could be solved. Future work will explore the possibility of squeezing-off the deepest completion (completion stage 1), or installation of a gas-lift system, in hopes of realizing this potential. It should be noted, however, that full realization of this potential will not materially change the economic outcome of the project well.

Notwithstanding the economic failure of this project well, it should be emphasized that directional drilling as a development strategy for the Devonian Shale cannot be tested with one well. A more accurate assessment of directional drilling results and additional insight into to the question of fracture system continuity will be revealed only as additional wells are drilled.

\section{SELECTED REFERENCES}

Caramanica, Frank P. 1988. A Geologic Model of Gas Production From the Lower Huron: Eastern Devonian Gas Shales Technology Review. Gas Research Institute, Volume 5, Numbers 2 and 3, pp. 4-16. 
Graham, Reuben L. 1991. Topical Well Report, Boggs \#1240 - Deviated Well, Sterling Drilling and Production Company: Exploration - Production Studies in Newly Drilled Devonian Shale Gas Wells. Gas Research Institute. Contract No. 5090-213-2016.

Lowery, Patrick H., Terence Hamilton-Smith, and R. Michael Peterson. 1988. Gas Production Controlled By Geological Features: GRI CSW No. 2 Area. Eastern Devonian Gas Shales Technology Review. Gas Research Institute. Volume 5, Numbers 2 and 3, pp. 17-27.

Muncey, Gery, 1990. PrimeEnergy/DOE/GRI Slant Well: A Directional Drilling Case History, Proceedings of the Natural Gas R\&D Contractors Review Meeting, ed.s R.D. Malone, H.D. Shoemaker, C.W. Byrer, DOE/METC-91/6117 (Conf901117).

Muncey, Gery. 1989a. Upcoming Plans for the DOE/Sterling/GRI/Columbia Slant Well Project. Proceedings of the Natural Gas R\&D Contractors Review Meeting, ed.s C.A. Komar, R.D. Malone, and C.W. Byrer, DOE/METC-89/6103 (Conf890492).

Muncey, Gery, Richard Carden. 1989b. Additional Field Experiments II: Cooperative Slant Well Research. Presented at the Gas Research Institute Devonian Gas Shales Workshop and Short Courses, September 26 and 27.

Sweeny, Joe. 1986. Oil and Gas Report and Maps of Wirt, Roane, and Calhoun Counties, West Virginia. Bulletin B-40, West Virginia Geological and Economic Survey, pp. 1-102.

Yost, Albert B., II , R. Carden, J.G. Muncey, W.E. Stover, and R.J. Scheper. 1990. Air Drilling and Multiple Hydraulic Fracturing of a 72 Degree Slant Well in Devonian Shale. Presented at the SPE Eastern Regional Conference and Exhibition, Columbus, Ohio, October 31 - November 2. 
Appendix A

DAILY DRILLING REPORTS 
WELL NAME: Boggs \#1240

DEPTH: 165

FORMATION:

FOOTAGE: 165

ROTATING WEIGHT:
DATE: $7 / 11 / 89$ REPORT TIME: $7: 00$ a m ACTIVITY: Drilling

HLD:

DAY: 1

BIT RECORD:

\begin{tabular}{lllllllllll}
$\begin{array}{l}\text { Bit } \\
\text { \# }\end{array}$ & Size & Type & $\begin{array}{c}\text { Serial } \\
\text { Manuf }\end{array}$ & $\begin{array}{l}\text { Depth } \\
\text { In }\end{array}$ & Out & $\begin{array}{c}\text { Foot- Ft/ } \\
\text { Age }\end{array}$ & $\begin{array}{l}\text { Hr } \\
\text { Wt }\end{array}$ & Rpm Condition \\
\hline 1 & $171 / 2$ F3J & Smith MB3191 & 0 & 165 & 17.8 & $2-15$ & 70
\end{tabular}

AIR RATE: $2100 \mathrm{scf} \mathrm{m}$ MIST RATE: BBLS/HR PRESSURE: 100 ADDITIVES:

BHA: Bit, X-0, 2-8" DC'S, 3-6" DC'S

SURVEYS:

GAS: C1:

, C2:

, C3:

, C4:

, C5: ,

C5+: ,

TOT:

SHOWS:

TIME BREAKDOWN AND COMMENTS:

FROM TO HRS

7:00 - $\quad 4: 15 \mathrm{pm} \quad 91 / 4$ Move in and rig up drilling rig (Exeter \#53)

4:15 - $\quad 7: 15 \mathrm{pm} \quad 31 / 2$ Drill rat hole and mouse hole

$7: 45 \quad-\quad 10: 00 \mathrm{pm} \quad 21 / 4$ Spud at $7 ; 45 \mathrm{pm} 7 / 10 / 89$. Drilling

10:00 - 12:00 mid 2 Work on compressors. Pull bit and remove jets.

12:00 - 7:00 am 7 Drilling. Hit water at 75 ,

DWC $\quad 16,038 \quad$ CWC $\quad 16,038$ 
WELL NAME: Boggs \#1240

DEPTH: 394

FOOTAGE: 229

FORMATION: Shale

ROTATING WEIGHT:
DATE: $7 / 12 / 89$ REPORT TIME: 7:00 am ACTIVITY: Nipple up

HLD: TORQUE:

DAY: 2

\section{BIT RECORD:}

\begin{tabular}{|c|c|c|c|c|c|c|c|c|c|c|}
\hline $\begin{array}{c}\text { Bit } \\
\#\end{array}$ & Size & Type & Manuf & $\begin{array}{c}\text { Serial } \\
\#\end{array}$ & In & $\begin{array}{l}\text { th } \\
\text { Out }\end{array}$ & $\begin{array}{l}\text { Foot- } \\
\text { Age }\end{array}$ & $\begin{array}{l}\mathbf{F t} / \\
\mathbf{H r}\end{array}$ & $w_{t}$ & Rpm Condition \\
\hline 1 & 17 & F $3 \mathrm{~J}$ & Smith & MB3193 & 0 & 394 & 22.2 & 15 & 70 & $1-3-1$ \\
\hline
\end{tabular}

AIR RATE: $2100^{\circ} \mathrm{scfm}$

MIST RATE:

BBLS/HR PRESSURE: 150 ADDITIVES:

BHA: Bit, X-0, 2-8" DC's, X-0, 10-6" DC's SURVEYS:

GAS: C1: $\quad$ C2: C3: C4: C5: , C5+: , TOT: SHOWS:

\begin{tabular}{|c|c|c|c|}
\hline FROM & TO & HRS & \multirow[b]{2}{*}{ Service rig and air } \\
\hline 7:00 & $7: 30$ & $11 / 2$ & \\
\hline 7:30 & $4: 00$ & $81 / 2$ & Drilling to $394^{\prime} \mathrm{KB}$ \\
\hline $4: 00$ & $4: 45$ & $3 / 4$ & Circulate and condition hole \\
\hline $4: 45$ & $5: 45$ & 1 & TOOH \\
\hline $5: 45$ & $7: 15$ & $11 / 2$ & $\begin{array}{l}\text { Rig up and run } 9 f \text { ts } 133 / 8^{\prime \prime}, 54.5 \# / \mathrm{ft} \text { casing } \\
\text { Landed casing at } 371.75^{\circ} \mathrm{GL}, 381.75^{\prime} \mathrm{KB} \text {. }\end{array}$ \\
\hline $7: 15$ & $9: 00$ & $13 / 4$ & $\begin{array}{l}\text { Cement } w / 20 \text { bbls } 6 \% \text { gel containing } 2.5 \mathrm{ppb} \text { celloflake, } \\
10 \text { bbls water, } 260 \text { sxs Class " } \mathrm{A}^{\prime} \text { cement } \mathrm{w} / 2 \% \mathrm{CaCl}_{2} \text { and }\end{array}$ \\
\hline & & & $\begin{array}{l}1 / 8 \text { pps celloflake mixed at } 15.6 \text { ppg. Displaced w/59.5 } \\
\text { bbls water. Bumped plug with } 480 \text { pls. }\end{array}$ \\
\hline 9:00 & $5: 00$ & 8 & WOC \\
\hline $5: 00$ & $7: 00$ & 2 & Nipple up \\
\hline
\end{tabular}

DWC $6,794 \quad$ CWC 22,832 
WELL NAME: Boggs \#1240

DEPTH: 1160

- FORMATION:

FOOTAGE: 766

ROTATING WEIGHT:
DATE: 7/13/89 REPORT TIME: 7:00 a m ACTIVITY: Drilling

HLD:

DAY： 3

\section{TORQUE:}

BIT RECORD:

\begin{tabular}{|c|c|c|c|c|c|c|c|c|c|c|}
\hline $\begin{array}{c}\text { Bit } \\
\#\end{array}$ & Size & Type & Manuf & $\begin{array}{c}\text { Serial } \\
\#\end{array}$ & In ${ }^{\text {Depth }}$ Out & $\begin{array}{l}\text { Foot- } \\
\text { Age }\end{array}$ & $\begin{array}{l}\mathrm{Ft} / \\
\mathrm{Hr}\end{array}$ & $W_{t}$ & Rpm & Condition \\
\hline ( & $121 /$ & $F-2$ & Smith & XF8405 & 394 & 766 & 46.4 & 40 & 80 & \\
\hline
\end{tabular}

AIR RATE: $2100 \mathrm{scf} m$ MIST RATE: BBLS/HR PRESSURE: 100 ADDITIVES:

BHA: Bit, Y-0, 2-8" DC's, X-0, 15-6 " DC's SURVEYS:

GAS: C1: $\quad$ C2: C3: $\quad$ C4: C5t , , C5: TOT: SHOWS:

\begin{tabular}{|c|c|c|}
\hline & & $8: 30$ \\
\hline $11: 00$ & - & $12: 00$ \\
\hline $12: 00$ & - & $1: 00$ \\
\hline $1: 00$ & - & $5: 45$ \\
\hline $5: 45$ & - & $7: 15$ \\
\hline $7: 15$ & - & $7: 00$ \\
\hline
\end{tabular}

DWC 9,745

CWC 32,577

\section{HRS}

$11 / 2$ Wait on welder

$21 / 2$ Finish nippling up

1 TIH

1 Drill out

4 3/4 Dry out hole and drill

$11 / 2$ Rig repair

$113 / 4$ Drilling 
WELL NAME: Boggs \#1240

DEPTH: 1650

FORMATION: Salt sand

ROTATING WEIGHT:
DATE: $7 / 14 / 89$ REPORT TIME: 7:00 am ACTIVITY: Drilling

HLD: TORQUE:

DAY: 4

BIT RECORD:

\begin{tabular}{|c|c|c|c|c|c|c|c|c|c|c|c|}
\hline $\begin{array}{c}\text { Bit } \\
\# \\
\end{array}$ & Size & Type & Manuf & $\begin{array}{c}\text { Serial } \\
\#\end{array}$ & In $^{I}$ & $\begin{array}{l}\text { th } \\
\text { Out }\end{array}$ & $\begin{array}{l}\text { Foot- } \\
\text { Age }\end{array}$ & $\begin{array}{l}\mathrm{Ft} / \\
\mathrm{Hr}\end{array}$ & $W_{t}$ & Rpm & Condition \\
\hline - & 12 & & Smith & $X F$ & 39 & 1359 & 965 & 47.1 & 45 & 70 & $5-8-1 / 4$ \\
\hline 3 & $121 /$ & $\mathrm{F}-2$ & Smith & XH3806 & 135 & & 291 & 29.1 & 45 & 60 & \\
\hline
\end{tabular}

AIR RATE: $2100 \mathrm{scf} m$ MIST RATE: 10 BBLS/HR PRESSURE: 150 ADDITIVES:

BHA: Same

SURVEYS:

GAS: C1:
SHOWS: Gas show at $1420^{\circ}$

, C3: , C4:

, C5: ,

C5+: ,

TOT:

TIME BREAKDOWN AND COMMENTS:

\begin{tabular}{|c|c|c|}
\hline \multicolumn{2}{|c|}{ FROM } & TO \\
\hline $7: 00$ & - & $7: 30$ \\
\hline $7: 30$ & - & $11: 30$ \\
\hline $11: 30$ & - & $3: 45$ \\
\hline $3: 45$ & - & 8:00 \\
\hline $8: 00$ & - & $2: 30$ \\
\hline $2: 30$ & - & $3: 30$ \\
\hline $3: 30$ & - & $7: 00$ \\
\hline
\end{tabular}

HRS

DWC 14,121

CWC 46,698 
WELL NAME: Boggs \#1240

DEPTH: 2010

FORMATION: Shale

ROTATING WEIGHT:
FOOT AGE: 360
DATE: $7 / 15 / 89$ REPORT TIME: 7:00 a m ACTIVITY: Trip

HLD: $\quad$ TORQUE:

DAY： 5

BIT RECORD:

\begin{tabular}{|c|c|c|c|c|c|c|c|c|c|c|c|}
\hline $\begin{array}{l}\text { Bit } \\
\#\end{array}$ & Size & Type & Manuf & $\begin{array}{c}\text { Serial } \\
\#\end{array}$ & In & $\begin{array}{l}\text { th } \\
\text { Out }\end{array}$ & $\begin{array}{l}\text { Foot- } \\
\text { Age }\end{array}$ & $\begin{array}{l}\mathrm{Ft} / \\
\mathrm{Hr}\end{array}$ & $w_{t}$ & Rpm & Condition \\
\hline & & & & $\mathrm{x}$ & 13 & 1848 & 48 & & & 60 & $4-6-1 / 4$ \\
\hline 4 & 121 & HP625 & Reed & EB 1134 & 1848 & 2010 & 162 & 32.4 & 35 & 60 & \\
\hline
\end{tabular}

AIR RATE: $2100 \mathrm{scfm}$ MIST RATE: 10 BBLS/HR PRESSURE: 150 ADDITIVES:

BHA: Same SURVEYS:

GAS: C1: $\quad$ C2: C3: C4: C5: , C5+: , TOT: SHOWS:

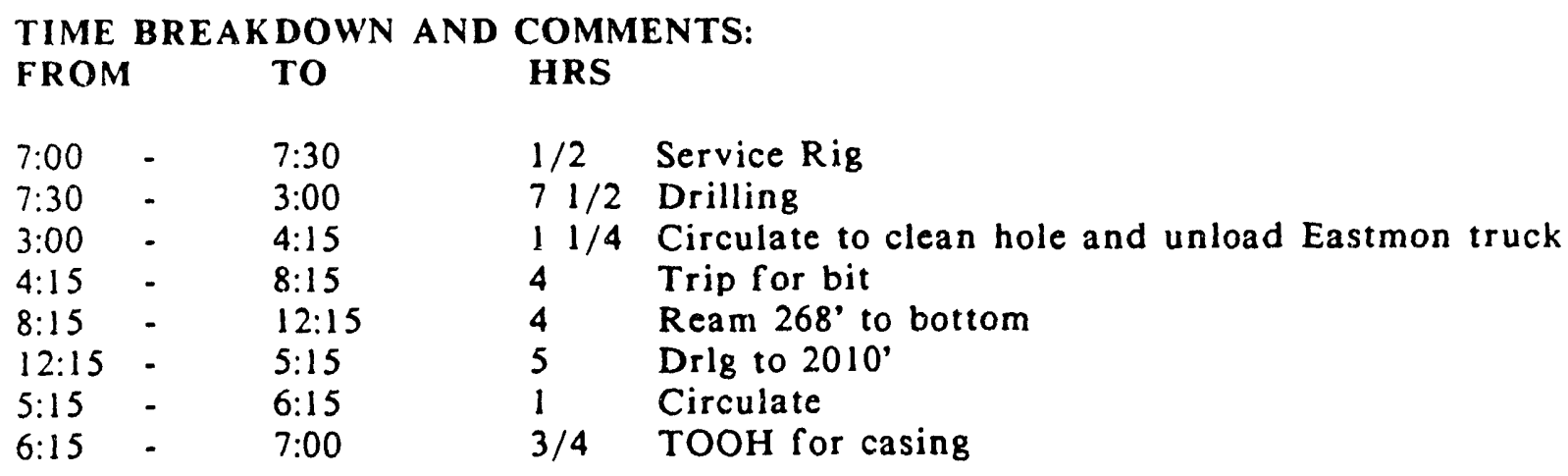

Base of Injun at 1915

DWC $8,786 \quad$ CWC 55,484 
WELL NAME: Boggs \#1240 DEPTH: 2010 FORMATION: FOOT AGE: 0 ROTATING WEIGHT:
DATE: $7 / 16 / 89$ REPORT TIME: 7:00 am ACTIVITY: Waiting on flange HLD: TORQUE:

DAY: 6

\section{BIT RECORD:}

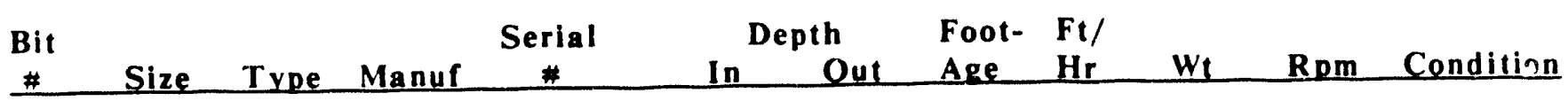

\section{AIR RATE:}

MIST RATE:

BBLS/HR PRESSURE:

ADDITIVES:

BHA:

SURVEYS:

GAS: C1:

, C2:

, C3:

, C4:

, C5: ,

C5+: ,

TOT:

SHOWS:

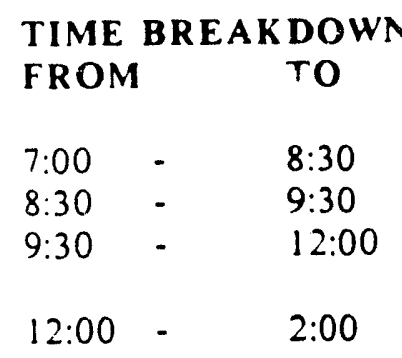

$2: 00 \quad-\quad 2: 00$

$2: 00 \quad-\quad 7: 00$

12

\section{COMS}

$11 / 2$ TOOH Lay down 2-7 "DC's"

1 Nipple down. Rig up to run $95 / 8^{\text {n }}$ casing.

$21 / 2$ Run 45 jts $95 / 8^{\prime \prime} 36$ J-55 sttc casing.

Landed casing at $1988.90^{\circ} \mathrm{KB}$,

2 Rig up Dowell. Cement with 5 bbls water, 20 bbls

$6 \%$ gel, 11 bbls water, 384 sxs $50 / 50$ poz w/2\% CaCl 2

and $1 / 8$ pps cellorlake, 100 sxs Class " $A$ " cement $w / 2 \% \mathrm{CaCl}_{2}$ and $1 / 8$ pps celloflake. Displaced with $154 \mathrm{bbls}$ water. Bumped plug at $2 \mathrm{pm} w / 850 \mathrm{psi}$. Good returns while cementing.

DWC 19,981 


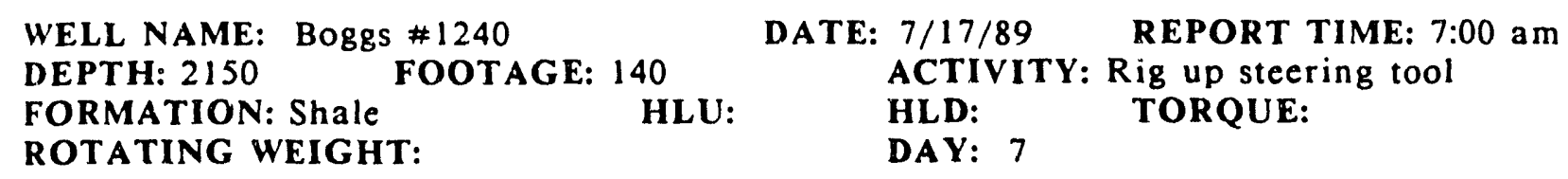

\begin{tabular}{|c|c|c|c|c|c|c|c|c|c|c|}
\hline $\begin{array}{c}\text { Bit } \\
\#\end{array}$ & Size & Type & Manuf & $\begin{array}{c}\text { Serial } \\
\#\end{array}$ & In & $\begin{array}{l}\text { th } \\
\text { Out }\end{array}$ & $\begin{array}{l}\text { Foot- } \\
\text { Age }\end{array}$ & $\begin{array}{l}\text { Ft/ } \\
\mathbf{H r}\end{array}$ & $w_{t}$ & Rom Condition \\
\hline $\begin{array}{l}5 \\
6\end{array}$ & $\begin{array}{ll}8 & 3 / 4 \\
8 & 1 / 2\end{array}$ & $\begin{array}{l}\text { F3H } \\
\text { F4 }\end{array}$ & $\begin{array}{l}\text { Smith } \\
\text { Smith }\end{array}$ & $\begin{array}{l}\mathrm{KD} 4958 \\
\mathrm{KH} 2634\end{array}$ & $\begin{array}{l}2010 \\
2150\end{array}$ & 2150 & 140 & 93.3 & 20 & 70 \\
\hline
\end{tabular}

AIR RATE: $2100 \mathrm{scf} m$ MIST RATE: BBLS/HR PRESSURE: 100 ADDITIVES:

BHA:

SURVEYS: $1^{\circ}, \quad \mathrm{N} 60^{\circ} \mathrm{E}^{\circ}, \quad$ @2097,

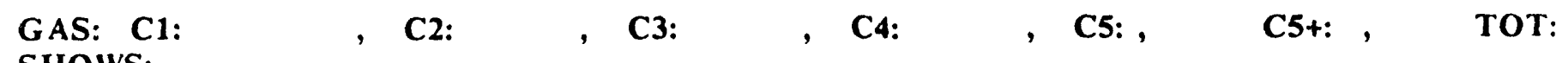

SHOWS:

\begin{tabular}{|c|c|c|}
\hline $9: 15$ & - & $10: 15$ \\
\hline $10: 15$ & - & $3: 30$ \\
\hline $3: 30$ & - & $5: 30$ \\
\hline $5: 30$ & - & $7: 00$ \\
\hline $7: 00$ & - & $8: 30$ \\
\hline $8: 30$ & - & $11: 30$ \\
\hline $11: 30$ & 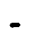 & $3: 00$ \\
\hline 3:00 & - & $5: 30$ \\
\hline $5: 30$ & - & $7: 00$ \\
\hline
\end{tabular}

COMMENTS:

\section{HRS}

DWC 10,090

CWC 76,555

DMC 0

CMC 2,815 
STERLING DRILLING \& PRODUCTION

WELL NAME: Boggs \#1240

DEPTH: 2345 FOOTAGE: 195

FORMATION: Siltstone \& sand

ROTATING WEIGHT:
DATE: $7 / 18 / 89$ REPORT TIME: 7:00 a m ACTIVITY: Drilling

HLD: 66,000 TORQUE:

DAY: 8

\section{BIT RECORD:}

\begin{tabular}{|c|c|c|c|c|c|c|c|c|c|c|}
\hline $\begin{array}{l}\text { Bit } \\
\#\end{array}$ & Size & Type & Manuf & $\begin{array}{c}\text { Serial } \\
\quad \#\end{array}$ & In $\quad$ Out & $\begin{array}{l}\text { Foot- } \\
\text { Age }\end{array}$ & $\begin{array}{l}\mathrm{Ft} / \\
\mathrm{Hr}\end{array}$ & $w_{t}$ & Rpm & Condition \\
\hline 6 & $81 / 2$ & F4 & Smith & KH2634 & 2150 & 195 & 11.8 & $2-7$ & $150-2$ & \\
\hline
\end{tabular}

AIR RATE: $1637 \mathrm{scf} m$ MIST RATE: 10 BBLS/HR PRESSURE: 500

ADDITIVES: Soda Ash, Poly pac, gel, RCI, soap

BHA: Bit, mtr, X-0, X-0, FS, MSS, X-0, monel, monel, X-0, 9-6" DC's, X-0

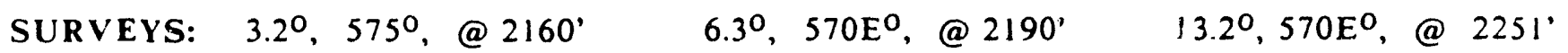

$15.6^{\circ}, 566 \mathrm{E}^{\circ}, @ 2282^{\prime}$

GAS: C1: $0 \quad$ C2: C3: C4: C5: , C5t: , TOT:

SHOWS: 3 units at $2288^{\circ}$

TIME BREAKDOWN AND COMMENTS:

$\begin{array}{llll}\text { FROM } & \text { TO } & \text { HRS } & \\ \text { 7:00 - } & 11: 00 & 4 & \text { Rig up steering tool and side entry sub } \\ 11: 00 \mathrm{am}- & 8: 00 \mathrm{pm} & 81 / 2 & \text { Drilling } 1 / 2 \text { connection } \\ 8: 00- & 8: 30 & 1 / 2 & \text { Service air and rig } \\ 8: 30- & 10: 30 & 2 & \text { Work on soap pumps } \\ 10: 30- & 7: 00 & 8 & \text { Drilling } 1 / 2 \text { connection }\end{array}$

Coordinates@ 2282' $1.74^{\prime} \mathrm{N} \quad 37.14 \mathrm{E} \quad$ Clos $37.17 \quad 87.31^{\circ}$

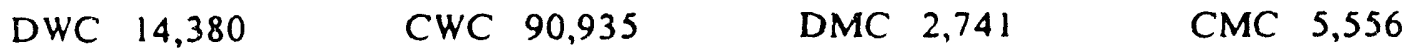


WELL NAME: Boggs \#1240

DEPTH: 2485 FOOTAGE: 140

FORMATION: Shale $\&$ siltstone

ROTATING WEIGHT:
DATE: $7 / 19 / 89$ REPORT TIME: 7:00 a m ACTIVITY: Drilling

HLD: 64,000 TORQUE:

DAY: 9

BIT RECORD:

\begin{tabular}{|c|c|c|c|c|c|c|c|c|c|c|c|}
\hline $\begin{array}{c}\text { Bit } \\
\#\end{array}$ & & & & $\begin{array}{c}\text { Serial } \\
\#\end{array}$ & In & $\begin{array}{l}\text { th } \\
\text { Out }\end{array}$ & $\begin{array}{l}\text { Foot- } \\
\text { Age }\end{array}$ & $\begin{array}{l}\mathrm{Ft} / \\
\mathrm{Hr}\end{array}$ & Wt & Rpm & Condition \\
\hline & $81 / 2$ & $\begin{array}{l}F 4 \\
F-4\end{array}$ & Smith & $\begin{array}{l}\mathrm{KH} 2634 \\
\mathrm{KH} 2634\end{array}$ & $\begin{array}{l}2150 \\
2362\end{array}$ & 2362 & $\begin{array}{l}212 \\
123\end{array}$ & $\begin{array}{l}10.6 \\
12.9\end{array}$ & $\begin{array}{l}2-8 \\
2-10\end{array}$ & $\begin{array}{l}150 \\
140\end{array}$ & $2-2-I$ \\
\hline
\end{tabular}

AIR RATE: 1637 scf m MIST RATE: 9 BBLS/HR PRESSURE: 530 ADDITIVES: Same

BHA: Bit $2^{\circ}$ bit motor, FS, MSS, X-0, 2-6 1/2 monels, X-0, 9-6n DC's, X-0 Total 354.15

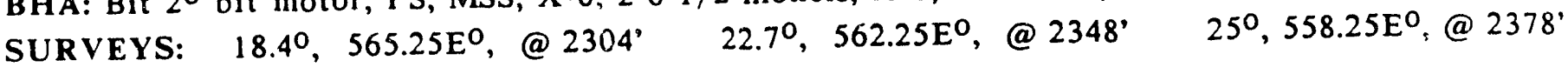
$27.3^{\circ}, 553.25 \mathrm{E}^{\circ}$,@2411'

GAS: C1: $\quad$ C2: $\quad$ C3: $\quad$ C4: C5: , C5+: , TOT: SHOWS:

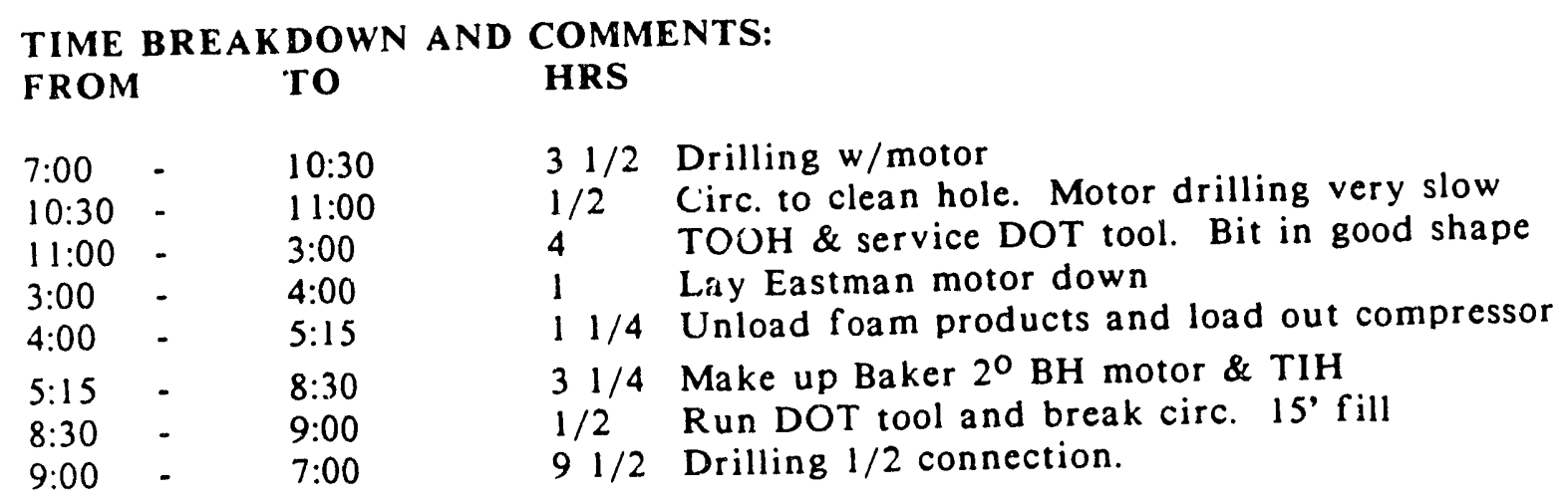

Coordinates@2411' TVD 2399.05 21.98's 79.51'E

Closure $82.49^{\prime}$ s $74.55 \mathrm{E}$

$\begin{array}{llllll}\text { DWC } & 17,748 & \text { CWC } & 108,683 & \text { DMC } & 2,650\end{array}$ 
WELL NAME: Boggs \#1240 DEPTH: 2548 FOOTAGE: 63 FORMATION: Siltstone ROTATING WEIGHT:
DATE: 7/20/89 REPORT TIME: 7:00 a m ACTIVITY: Reaming

HLU: 80,000 HLD: 60,000 TORQUE:

DAY: 10

\section{BIT RECORD:}

\begin{tabular}{|c|c|c|c|c|c|c|c|c|c|c|c|}
\hline $\begin{array}{c}\text { Bit } \\
\#\end{array}$ & Size & Type & Manuf & $\begin{array}{c}\text { Serial } \\
\#\end{array}$ & In $^{\text {DeI }}$ & $\begin{array}{l}\text { th } \\
\text { Out }\end{array}$ & $\begin{array}{l}\text { Foot- } \\
\text { Age }\end{array}$ & $\begin{array}{l}\mathrm{Ft} / \\
\mathrm{Hr}\end{array}$ & $W_{t}$ & Rom & Condition \\
\hline R6 & $\begin{array}{ll}8 & 1 / 2 \\
8 & 1 / 2\end{array}$ & $\begin{array}{l}F-4 \\
4 G I\end{array}$ & $\begin{array}{l}\text { Smith } \\
\text { Smith }\end{array}$ & $\begin{array}{l}\text { KH2364 } \\
\text { LZ3192 }\end{array}$ & 2362 & 2548 & 186 & 9.8 & $2-10$ & 140 & $5-4-1 / 8$ \\
\hline
\end{tabular}

AIR RATE: 3 -750's 1400 MIST RATE: 5 BBLS/HR PRESSURE: 120 ADDITIVES: Same

BHA: Bit, FS, 6pt, 2-monels, X-0, 9 DC's, X-0

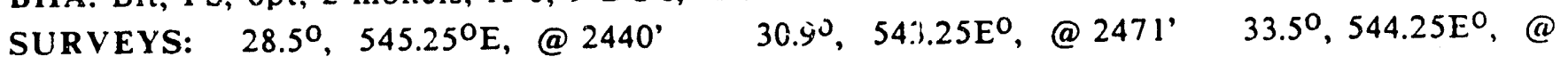
2492'

GAS: C1: $\quad$ C2: $\quad$ C3: $\quad$ C4: $\quad$ C5: , C5+: , TOT:

SHOWS:

TIME BREAKDOWN AND COMMENTS:

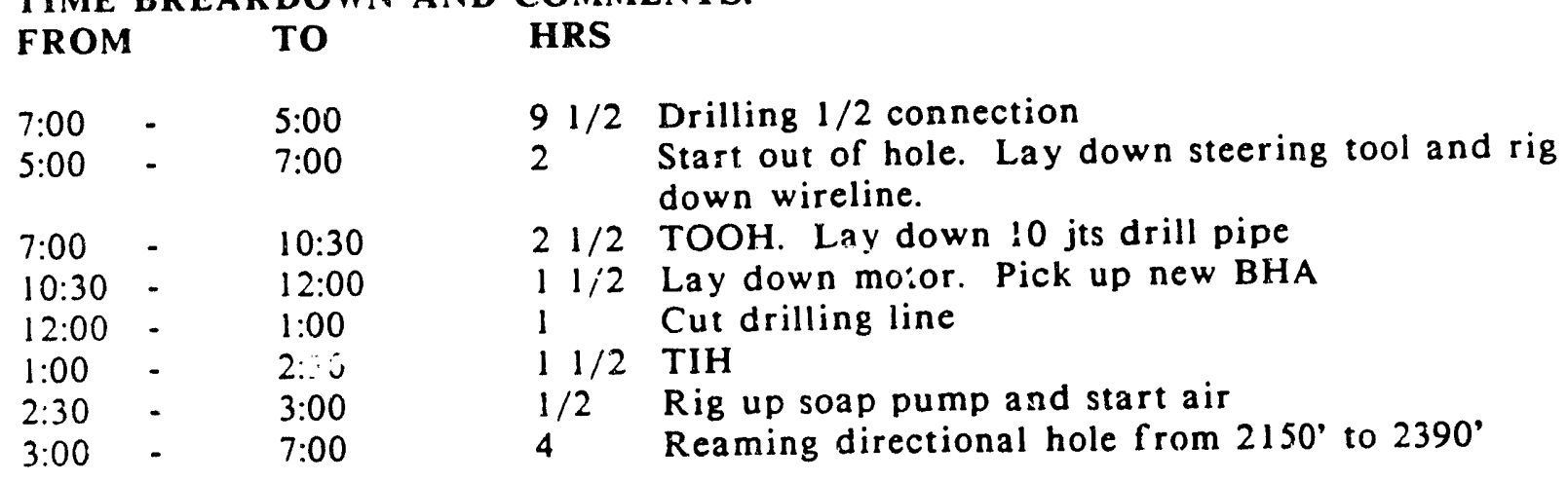

DWC 22,051 CWC $130,734 \quad$ DMC $3,683 \quad$ CMC 11,889 


\section{STERLING DRILLING \& PRODUCTION}

WELL NAME: Boggs \#1240

DEPTH: 281

FOOTAGE: 263

FORMATION: $70 \%$ shale $30 \%$ siltstone ROTATING WEIGHT: 55,000
DATE: $7 / 21 / 89$ REPORT TIME: 7:00 a m

ACTIVITY: Rig up steering tool

HLU: 100,000 HLD: 45,000 TORQUE: $1 / 2$ turn

DAY: 11

\section{BIT RECORD:}

\begin{tabular}{|c|c|c|c|c|c|c|c|c|c|c|c|}
\hline $\begin{array}{l}\text { Bit } \\
\#\end{array}$ & Size & Type & Manuf & $\begin{array}{c}\text { Serial } \\
\#\end{array}$ & In $^{D}$ & $\begin{array}{l}\text { th } \\
\text { Out }\end{array}$ & $\begin{array}{l}\text { Foot- } \\
\text { Age }\end{array}$ & $\begin{array}{l}\mathbf{F t} / \\
\mathrm{Hr}\end{array}$ & $W_{t}$ & Rpm & Condition \\
\hline & $81 / 2$ & $4 \mathrm{G}$ & mith & Lz & 25 & 2811 & 263 & 45.7 & 25 & 80 & $1-2-I$ \\
\hline
\end{tabular}

AIR RATE: 2600 MIST RATE: $\quad$ BBLS/HRPRESSURE: 110

ADDITIVES:

BHA: Bit $2^{\circ}$ motor, FS, MSS, X-0, 2-monels, X-0, --DC, XO

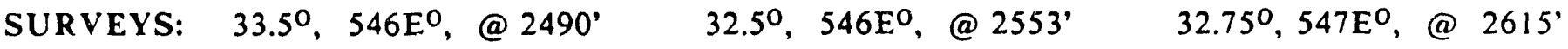
$33.75^{\circ}, 547 \mathrm{E}^{\circ}$, @2667'350,546E @2738

GAS: C1: C2: , C3: , C4: , C5: , C5+: , TOT:

SHOWS: 4 units at $2759^{\prime}$ (siltstone)

TIME BREAKDOWN AND COMMENTS:

FROM TO HRS

\begin{tabular}{|c|c|c|c|c|}
\hline 7:00 & - & $7: 30$ & $1 / 2$ & Service rig and air \\
\hline $7: 30$ & - & $9: 30$ & 2 & Ream to $2548^{\prime} \mathrm{KB}$ \\
\hline $9: 30$ & - & $10: 30$ & 1 & Drying hole \\
\hline $10: 30$ & - & $12: 30$ & 2 & Drilling \\
\hline $12: 30$ & - & $1: 30$ & 1 & Change rotating head rubber \\
\hline $1: 30$ & - & $2: 00$ & $1 / 2$ & Drilling \\
\hline $2: 00$ & - & 4:00 & 2 & Wait on survey line and rig up same \\
\hline 4:00 & - & $4: 45$ & $3 / 4$ & Run 3 surveys \\
\hline $4: 45$ & - & $6: 00$ & $11 / 4$ & Drilling \\
\hline $6: 00$ & - & $6: 45$ & $3 / 4$ & Circ \& survey \\
\hline $6: 45$ & - & $8: 15$ & $11 / 2$ & Drilling \\
\hline $8: 15$ & - & $9: 30$ & $11 / 4$ & Circ \& survey \\
\hline $9: 30$ & - & $10: 00$ & $1 / 2$ & Drilling \\
\hline 10:00 & - & $1: 30$ & $31 / 2$ & Circ \& TOOH. Lay down 8 DC's \\
\hline $1: 30$ & - & $3: 00$ & $11 / 2$ & Pu Baker $2^{\circ} \mathrm{BH}$ motor \\
\hline $3: 00$ & - & $4: 30$ & $11 / 2$ & TIH \\
\hline $4: 30$ & - & 7:00 & $21 / 2$ & Rig up steering tool \\
\hline
\end{tabular}

Coordinates@2738' 2675'TVD 142's 207'E 251'VS

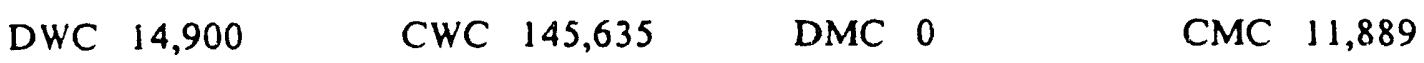


WELL NAME: Boggs \#1240

DEPTH: 3120

FORMATION: Shale

ROTATING WEIGHT:
DATE: $7 / 22 / 89$ REPORT TIME: $7: 00$ am ACTIVITY: Drilling

HLD: TORQUE:

DAY: 12

\section{BIT RECORD:}

\begin{tabular}{|c|c|c|c|c|c|c|c|c|c|c|}
\hline $\begin{array}{c}\text { Bit } \\
\#\end{array}$ & Size & Type & Manuf & $\begin{array}{c}\text { Serial } \\
\#\end{array}$ & In $\quad$ Out & $\begin{array}{l}\text { Foot- } \\
\text { Age }\end{array}$ & $\begin{array}{l}\text { Ft/ } \\
\mathrm{Hr}\end{array}$ & $w_{t}$ & $\mathbf{R p m}$ & Condition \\
\hline 8 & $81 / 2$ & $F-4$ & Smith & KJ4166 & 2811 & 309 & 19.3 & $5-7$ & 140 & \\
\hline
\end{tabular}

AIR RATE: 1768 MIST RATE: 9 BBLS/HR PRESSURE: 520 ADDITIVES:

HLU:

BHA: Same

SURVEYS: $37^{\circ}, 546 \mathrm{E}^{\circ}$, @ 2830'

$42^{\circ}, 546 \mathrm{E}^{\circ}$, @ 2890'

$47.4^{\circ}, 547 \mathrm{E}^{\circ}, @ 2950^{\circ}$

53․,549E,$@ 3012^{\circ}$

GAS: C1: C2: C C3: C4: C5: , C5+: , TOT:

SHOWS: 3 units at 3000 '

TIME BREAKDOWN AND COMMENTS:

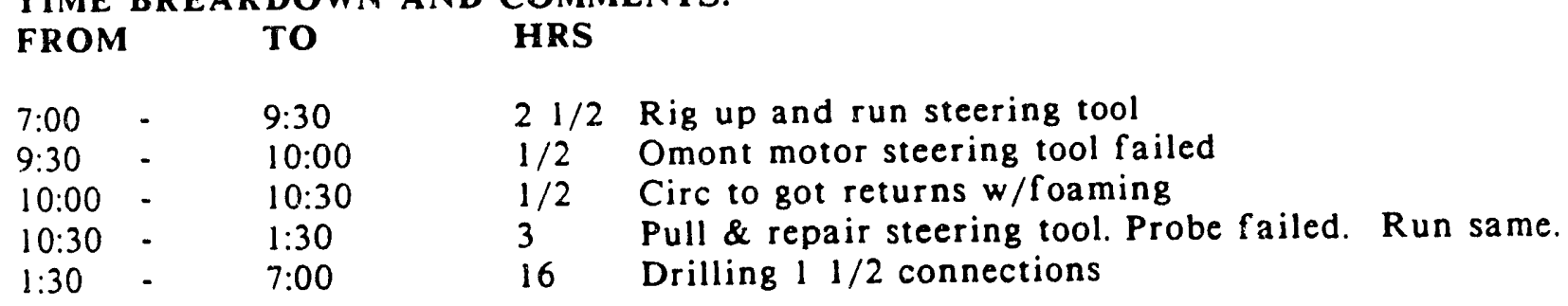

No fill on connections

Coordinates at 3012' 2878'TVD 267's 339'E 432'VS

Est. TD $7 / 27 / 89$

$\begin{array}{lllllll}\text { DWC } & 11,893 \quad \text { CWC } & 157,528 & \text { DMC } & 0 & \text { CMC } & 11,889\end{array}$ 
WELL NAME: Boggs \#1240

DEPTH: 3165 FOOTAGE: 45

FORMATION: Shale

ROTATING WEIGHT:

BIT RECORD:
DATE: $7 / 23 / 89$ REPORT TIME: 7:00 am ACTIVITY: Trip

HLD: TORQUE:

DAY: 13

\begin{tabular}{|c|c|c|c|c|c|c|c|c|c|c|}
\hline $\begin{array}{l}\text { Bit } \\
\#\end{array}$ & Size & Type & Manuf & $\begin{array}{c}\text { Serial } \\
\quad \#\end{array}$ & In Depth & $\begin{array}{l}\text { Foot- } \\
\text { Age }\end{array}$ & $\begin{array}{l}\mathrm{Ft} / \\
\mathrm{Hr}\end{array}$ & $W_{t}$ & $\mathbf{R p m}$ & Condition \\
\hline $\begin{array}{l}8 \\
\text { RR7 }\end{array}$ & $\begin{array}{ll}8 & 1 / 2 \\
8 & 1 / 2\end{array}$ & $\begin{array}{l}F-4 \\
4 G A\end{array}$ & $\begin{array}{l}\text { Smith } \\
\text { Smith }\end{array}$ & $\begin{array}{l}\text { KJ4166 } \\
\text { LZ3192 }\end{array}$ & $\begin{array}{l}2811 \\
3165\end{array}$ & 309 & 19.3 & $5-7$ & 140 & \\
\hline
\end{tabular}

AIR RATE: 1700

MIST RATE:

$11 \mathrm{BBLS} / \mathrm{HR}$

PRESSURE: 150

ADDITIVES: Same

BHA: Bit, 6pt, FS, 2 monels, X-0, DC, X-0

SURVEYS: $58.9^{\circ}, 548 \mathrm{E}^{\circ}$, @ 3074'

GAS: C1: $\quad$ C2: $\quad$ C3: $\quad$ C4: $\quad$, C5: , C5t: , TOT:

SHOWS: None

\begin{tabular}{lll}
\multicolumn{3}{l}{ TIME BREAKDOWN } \\
FROM & \multicolumn{1}{l}{ TO } \\
& & \\
$7: 00$ & - & $10: 30$ \\
$10: 30$ & - & $3: 15$ \\
& & \\
& & \\
$3: 15$ & - & $4: 15$ \\
$4: 15$ & - & $7: 30$ \\
$7: 30$ & - & $9: 15$ \\
$9: 15$ & - & $10: 00$ \\
$10: 00$ & - & $4: 00$ \\
$4: 00$ & - & $5: 30$ \\
$5: 30$ & - & $7: 00$
\end{tabular}

COMMENTS:

\section{HRS}

Coordinates@3074' TVD 2913'301'S 378'E 483' Vertical Sec.

EST TD $7 / 27 / 89$

DWC 12,009

CWC 169,627

DMC 0

CMC $\quad 11,889$ 
WELL NAME: Boggs \#1240 DEPTH: 3207 FOOTAGE: 42 FORMATION: Shale ROTATING WEIGHT:
DATE: $7 / 24 / 89$ REPORT TIME: 7:00 am ACTIVITY: Drilling

HLU: 75,000 HLD: 54,000 TORQUE:

DAY: 14

\section{BIT RECOR D:}

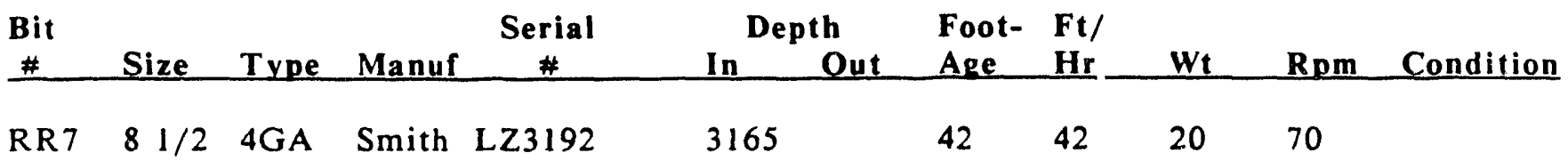
AIR RATE: 1539
MIST RATE:
0 BBLS/HR
PRESSURE: 100 ADDITIVES:

BHA: Bit, 6pt, FS, 2 monels, X-0, DC, X-0

SURVEYS: $58.9^{\circ}, 548 \mathrm{E}^{\circ}$, @ 3074'

$\begin{array}{llll}\text { GAS: C1: } & \text { C2: } \quad \text { C3: } \quad \text { C4: } \quad, \text { C5: , C5+: , TOT: } \\ \text { SHOWS: None }\end{array}$

\begin{tabular}{|c|c|c|}
\hline $7: 30$ & - & $1: 30$ \\
\hline $1: 30$ & - & $5: 00$ \\
\hline $5: 00$ & - & $5: 30$ \\
\hline $5: 30$ & - & $10: 00$ \\
\hline $10: 00$ & - & $11: 00$ \\
\hline $11: 00$ & - & $11: 30$ \\
\hline $11: 30$ & - & $2: 00$ \\
\hline $2: 00$ & - & $2: 45$ \\
\hline $2: 45$ & - & $4: 00$ \\
\hline $4: 00$ & 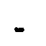 & $6: 00$ \\
\hline $6: 00$ & - & $7: 00$ \\
\hline
\end{tabular}

COMMENTS:

Fst $\quad$ TD $7 / 28 / 89$

DWC 10,993

DMC 0

CMC $\quad 11,889$ 


\section{STERLING DRILLING \& PRODUCTION}

WELL NAME: Boggs \#1240

DATE: 7/25/89 REPORT TIME: 7:00 am DEPTH: 3785 FOOTAGE: 578 ACTIVITY: Trip

FORMATION: Shale

HLU: 98,000

HLD: 42,000 TORQUE: 1rd

ROTATING WEIGHT: 65,000

DAY: 15

BIT RECORD:

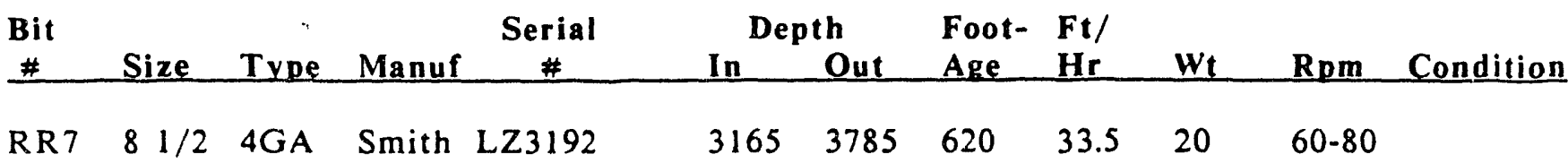

AIR RATE: 1539 MIST RATE: BBLS/HR PRESSURE: 100

ADDITIVES:

BHA: Same

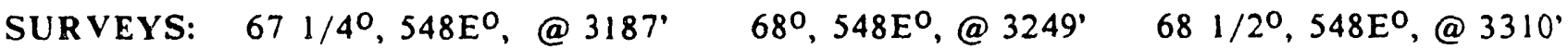

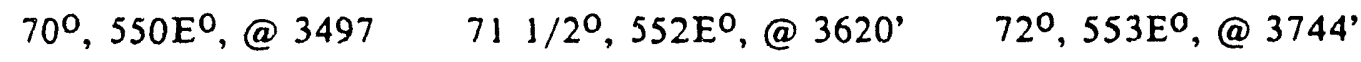

GAS: C1: , C2: , C3: , C4: C5: , C5t: , TOT:

SHOWS: $36153 \mathrm{u}, \quad 367018 \mathrm{u}, \quad 3728 \quad 8 \mathrm{u}, \quad 3734 \quad 7 \mathrm{u}, \quad 37749 \mathrm{u}$

TIME BREAKDOWN AND COMMENTS:

\begin{tabular}{|c|c|c|c|}
\hline FROM & To & HRS & \\
\hline $7: 00$ & $12: 15$ & $\begin{array}{ll}3 & 3 / 4 \\
1 & 1 / 2\end{array}$ & $\begin{array}{l}\text { Drig } \\
\text { Survey }\end{array}$ \\
\hline $12: 15$ & $1: 15$ & $i$ & Change rotating rubber \\
\hline $1: 15$ & $5: 45$ & $\begin{array}{l}133 / 4 \\
23 / 4\end{array}$ & $\begin{array}{l}\text { Drilling } \\
\text { Survey }\end{array}$ \\
\hline $5: 45$ & $6: 15$ & $1 / 2$ & Circ to clean hole \\
\hline $6: 15$ & 7:00 & $3 / 4$ & Survey \\
\hline
\end{tabular}

Coordinates@3744' 3156'TVD 704'S, 853'E 1106'VS

Est. TD $7 / 29 / 89$

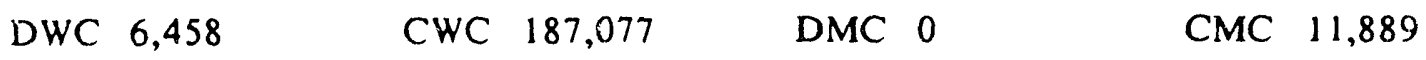


WELL NAME: Boggs \#1240

DEPTH: 3855

FORMATION:

FOOTAGE: 70

ROTATING WEIGHT:
DATE: $7 / 26 / 89$ REPORT TIME: 7:00 am ACTIVITY: Circulate

HLD: TORQUE:

DAY: 16

\section{BIT RECORD:}

\begin{tabular}{|c|c|c|c|c|c|c|c|c|c|c|c|}
\hline $\begin{array}{c}\text { Bit } \\
\#\end{array}$ & Size & Type & Manuf & $\begin{array}{c}\text { Serial } \\
\#\end{array}$ & In & $\begin{array}{l}\text { hut } \\
\text { Out }\end{array}$ & $\begin{array}{l}\text { Foot- } \\
\text { Age }\end{array}$ & $\begin{array}{l}\mathrm{Ft} / \\
\mathrm{Hr}\end{array}$ & Wt & Rpm & Condition \\
\hline $\begin{array}{l}R 7 \\
R 8\end{array}$ & $\begin{array}{ll}8 & 1 / 2 \\
8 & 1 / 2\end{array}$ & $\begin{array}{l}4 G A \\
F-4\end{array}$ & $\begin{array}{l}\text { Smith } \\
\text { Smith }\end{array}$ & $\begin{array}{l}\text { LZ3192 } \\
\text { RJ4166 }\end{array}$ & $\begin{array}{l}3165 \\
3785\end{array}$ & 3785 & $\begin{array}{l}620 \\
70\end{array}$ & $\begin{array}{l}33.5 \\
17.5\end{array}$ & 20 & $60-80$ & \\
\hline
\end{tabular}

AIR RATE: 1400

MIST RATE:

15 BBLS/HR

PRESSURE: 460 ADDITIVES:

BHA: Bit, $20 \mathrm{BH} \mathrm{mtr}, \mathrm{FS}, \mathrm{MSS}, \mathrm{X}-0,2$ monels, X-0, DC, X-0

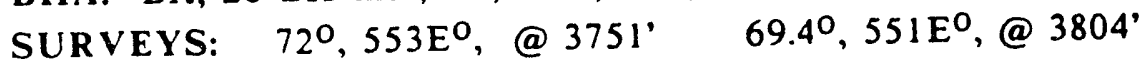

GAS: C1: , C2: , C3: , C4: , C5: , C5+: , TOT: 2 units

SHOWS: 3848 ' 8-9 units

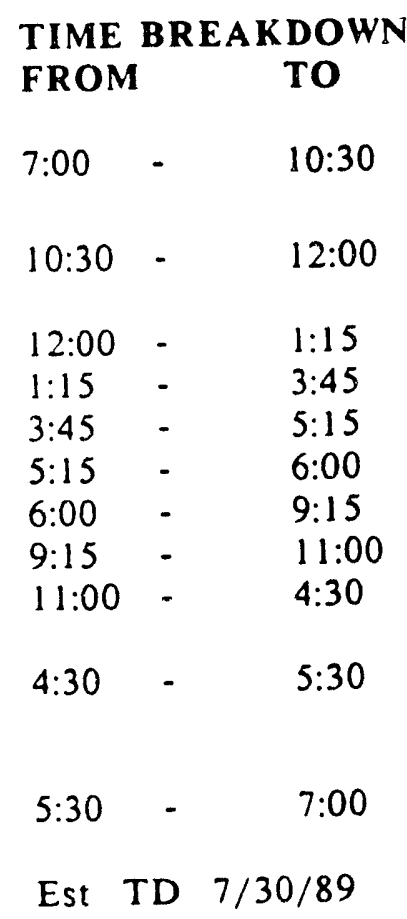

COMMENTS:

\section{HRS}

$\begin{array}{llllll}\text { DWC } & 13,570 & \text { CWC } & 200,647 & \text { DMC } & 4,409\end{array}$ 
WELL NAME: Boggs \#1240

DEPTH: 3908

FORMATION: Shale

ROTATING WEIGHT: 66,000
DATE: 7/26/89 REPORT TIME: 7:00 am ACTIVITY: Drlg

HLU: 90,000 HLD: 45,000 TORQUE: 1 rd

DAY: 16

\section{BIT RECORD:}

\begin{tabular}{|c|c|c|c|c|c|c|c|c|c|c|c|}
\hline Bit & & & & Serial & De & & $\begin{array}{l}\text { Foot- } \\
\text { Age }\end{array}$ & $\begin{array}{l}\mathbf{F t} / \\
\mathbf{H r}\end{array}$ & $W_{t}$ & $\mathbf{m}$ & ditio \\
\hline$\#$ & Size & Type & Manuf & & In & & & & & & 0 \\
\hline $\begin{array}{l}\text { RR8 } \\
9\end{array}$ & $\begin{array}{ll}8 & 1 / 2 \\
8 & 1 / 2\end{array}$ & $\begin{array}{l}F-4 \\
F-4\end{array}$ & $\begin{array}{l}\text { Smith } \\
\text { Smith }\end{array}$ & $\begin{array}{l}\text { KJ4166 } \\
\text { KF2972 }\end{array}$ & $\begin{array}{l}3785 \\
3885\end{array}$ & 3855 & $\begin{array}{l}70 \\
53\end{array}$ & $\begin{array}{l}17.5 \\
53\end{array}$ & $\begin{array}{l}5 \\
20\end{array}$ & $\begin{array}{l}140 \\
70\end{array}$ & $2-5-1 / 8$ \\
\hline
\end{tabular}

AIR RATE: 1450 MIST RATE: BBLS/HR PRESSURE: 120

ADDITIVES:

BHA: Bit, FS, 6pt, 2 monels, X-0, DC, X-0

SURVEYS:

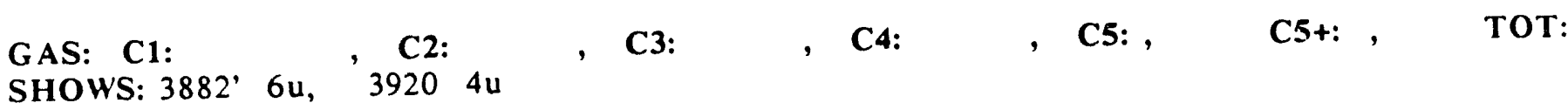

TIME BREAKDOWN AND COMMENTS:

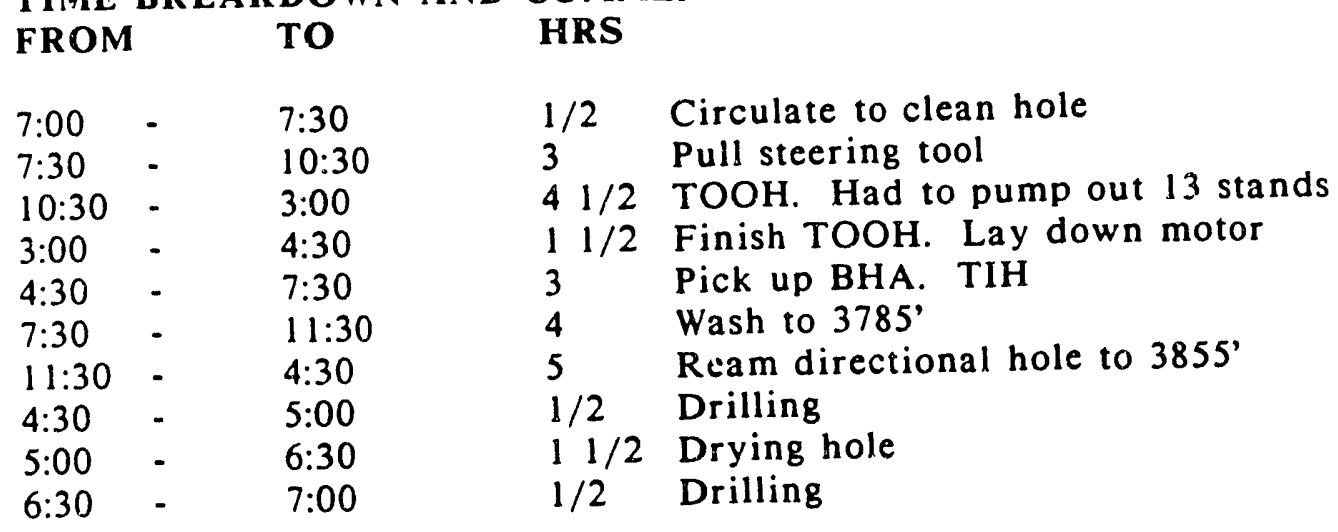

$7 / 29 / 89$ Est. TD

DWC $11,502 \quad$ CWC $212,547 \quad$ DMC $225 \quad$ CMC 16,523 
WELL NAME: Boggs \#1240

DEPTH: 4160 FOOTAGE: 252

FORMATION: Shale

ROTATING WEIGHT: 66,000
DATE: $7 / 28 / 89$ ACTIVITY: Survey

HLU: 95,000

HLD: 45,000 TORQUE: 1 rd

DAY: 18

BIT RECORD:

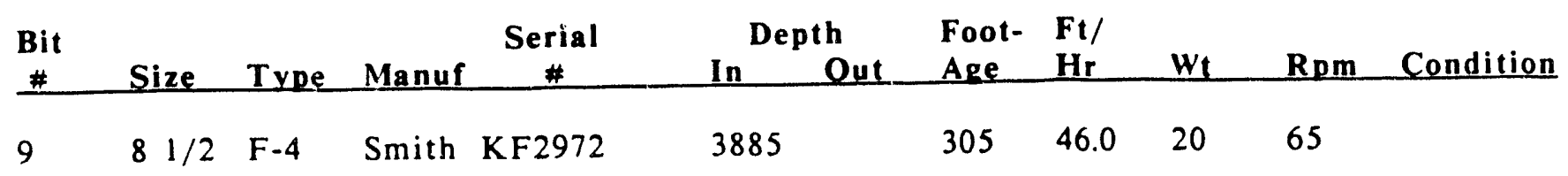

AIR RATE: 2300 MIST RATE: 0 BBLS/HR PRESSURE: 160

ADDITIVES:

BHA: Same

SURVEYS: $6514^{\circ}, 548 \mathrm{E}^{\circ}, @ 3897^{\prime} 66614^{\circ}, 550 \mathrm{E}^{\circ}$, @ 4117'

GAS: C1: C2: C3: C4: C5: , C5+: , TOT: SHOWS: $3920 \mathrm{5u}, \quad 39509 \mathrm{u}, \quad 396010 \mathrm{u}, 40167 \mathrm{u}, 404614 \mathrm{u}, 404414 \mathrm{u}, \quad 405220 \mathrm{u}$, $4080 \quad 12 \mathrm{u}$

TIME BREAKDOWN AND COMMENTS:

FROM TO HRS

$\begin{array}{lllll}7: 00 & - & 8: 45 & 13 / 4 & \text { Drlg \& trying to dry hole. No returns } \\ 8: 45 & - & 9: 30 & 3 / 4 & \text { Pull 120' \& become tight. Could not work up the hole } \\ 9: 30 & - & 11: 30 & 2 & \text { Circulate w/foam } \\ 11: 30 & - & 12: 30 & 1 & \text { POOH w/7 stands \& circ to clean hole } \\ 12: 30 & - & 2: 00 & 11 / 2 & \text { TIH \& wash } 3 \text { its to bottom } \\ 2: 00 & - & 3: 45 & 13 / 4 & \text { Circ. \& survey } \\ 3: 45 & - & 4: 45 & 1 & \text { Circ \& condition hole w/foam } \\ 4: 45- & 6: 45 & 2 & \text { Circulate } / \text { air to dry hole } \\ 6: 45- & 9: 30 & 23 / 4 \text { Drilling \& trying to dry hole } \\ 9: 30- & 11: 00 & 11 / 2 \text { Change air rig up to increase air volume from } \\ 11: 00- & 1: 00 & 2 & \text { Pulled } 7 \text { joints. Worked pipe \& got circ. } \\ 1: 00- & 3: 30 & 21 / 2 & \text { Ream back to bottom cleaning hole } \\ 3: 30 & - & 4: 30 & 1 & \text { Drilling } \\ 4: 30- & 6: 30 & 2 & \text { Circulate } \\ 6: 30 & 7: 00 & 1 / 2 & \text { Survey }\end{array}$

Coordinates at 4117' 3302' TVD, 926'S, 1114'E, 1449' VS

Est TD $7 / 29 / 89$

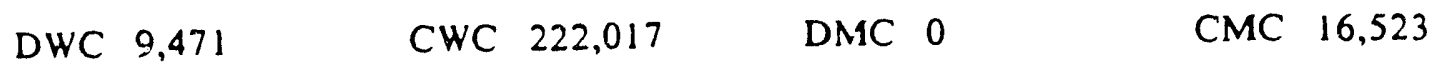


WELL NAME: Boggs \#1240 DEPTH: 4681 FOOTAGE: 526 FORMATION: Shale \& Siltstone ROTATING WEIGHT: 66,000
DATE: $7 / 29 / 89$ REPORT TIME: $7: 00$ a m ACTIVITY: Drilling

HLD: 30,000

DAY: 19

\section{BIT RECORD:}

\begin{tabular}{lllllllllll}
$\begin{array}{c}\text { Bit } \\
\#\end{array}$ & Size & Type & Manuf & $\begin{array}{c}\text { Serial } \\
\#\end{array}$ & In & $\begin{array}{c}\text { Depth } \\
\text { Out }\end{array}$ & $\begin{array}{l}\text { Foot- } \\
\text { Age }\end{array}$ & $\begin{array}{c}\text { Ft/ } \\
\text { Hr }\end{array}$ & Wt & Rom Condition \\
\hline 9 & $81 / 2$ & F-4 & Smith KF2972 & 3885 & 826 & 30.0 & 20 & $60-70$
\end{tabular}

AIR RATE: 2150 MIST RATE: 0 BBLS/HR PRESSURE: 160 ADDITIVES:

BHA: Same

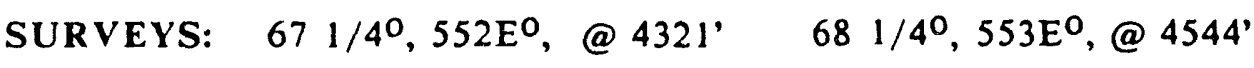

GAS: C1: $\quad$ C2: C3: C4: C5: , C5+: , . TOT: SHOWS: $420630 \mathrm{u}, 424512 \mathrm{u}, 425614 \mathrm{u}, 426812 \mathrm{u}, 427213 \mathrm{u}, 430616 \mathrm{u}, 4314$ $18 \mathrm{u}, \quad 431816 \mathrm{u}, \quad 434412 \mathrm{u}, 435612 \mathrm{u}, 436712 \mathrm{u}, 441612 \mathrm{u}, 442012 \mathrm{u}, 442812 \mathrm{u}$, $443716 \mathrm{u}, \quad$ (Background increased from 10 to 13 units) $450421 \mathrm{u}, 451024 \mathrm{u}, 455212 \mathrm{u}$, $456316 \mathrm{u}, 459817 \mathrm{u}, 462248 \mathrm{u}$, (Background increased to 19u) $465420 \mathrm{u}, 465921 \mathrm{u}$, 4674 29units

TIME BREAKDOWN AND COMMENTS:

\begin{tabular}{|c|c|c|c|c|}
\hline FRO & & TO & HRS & \\
\hline $7: 00$ & - & $7: 30$ & $1 / 2$ & Survey \\
\hline $7: 30$ & - & $3: 00$ & $7: / 2$ & Drilling \\
\hline $3: 00$ & - & $3: 30$ & $1 / 2$ & Survey \\
\hline $3: 30$ & - & $6: 15$ & $23 / 4$ & Drilling \\
\hline $6: 15$ & - & $7: 15$ & & Replace rotating head rubber \\
\hline $7: 15$ & - & $3: 00$ & $73 / 4$ & Drilling \\
\hline $3: 00$ & - & $4: 00$ & 1 & Circulate and survey \\
\hline $4: 00$ & - & $7: 00$ & 3 & Drilling \\
\hline
\end{tabular}

Coordinates@4544' 3467'TVD 1170'S 1423'E 1842'VS

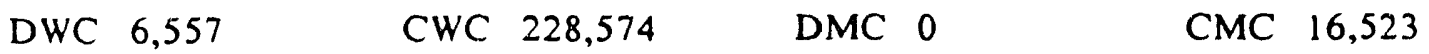


WEL.L NAME: Boggs \#1240

DATE: $7 / 30 / 89$ REPORT TIME: 7:00 a m

DEPTH: 4833 FOOTAGE: 152 ACTIVITY: Logging

FORMATION: Siltstone \& shale HLU: 140,000 HLD: 30,000 TORQUE: $21 / 4 \mathrm{rds}$

ROTATING WEIGHT: 66,000 DAY: 20

BIT RECORD:

\begin{tabular}{|c|c|c|c|c|c|c|c|c|c|c|c|}
\hline $\begin{array}{l}\text { Bit } \\
\text { \# }\end{array}$ & Size & Type & Manuf & $\begin{array}{c}\text { Serial } \\
\#\end{array}$ & In & $\begin{array}{l}\text { th } \\
\text { Out }\end{array}$ & $\begin{array}{l}\text { Foot- } \\
\text { Are }\end{array}$ & $\begin{array}{l}\mathrm{Ft} / \\
\mathrm{Hr}\end{array}$ & $w_{t}$ & Rom & Condition \\
\hline 9 & $81 / 2$ & $F-4$ & Smith & KF2972 & 3885 & 4833 & 978 & 29.0 & 20 & $60-70$ & $1-3-1$ \\
\hline
\end{tabular}

AIR RATE: 2085 MIST RATE: 0 BBLS/HR PRESSURE: 160 ADDITIVES:

BHA: Same

SURVEYS: $6914^{\circ}, 556 E^{\circ}$, @ 4789

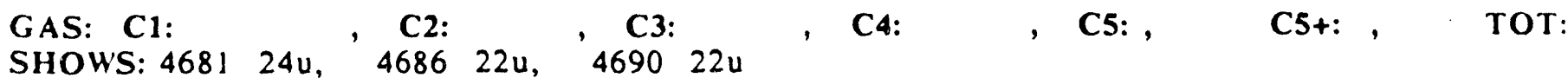

TIME BREAKDOWN AND COMMENTS:

FROM TO HRS

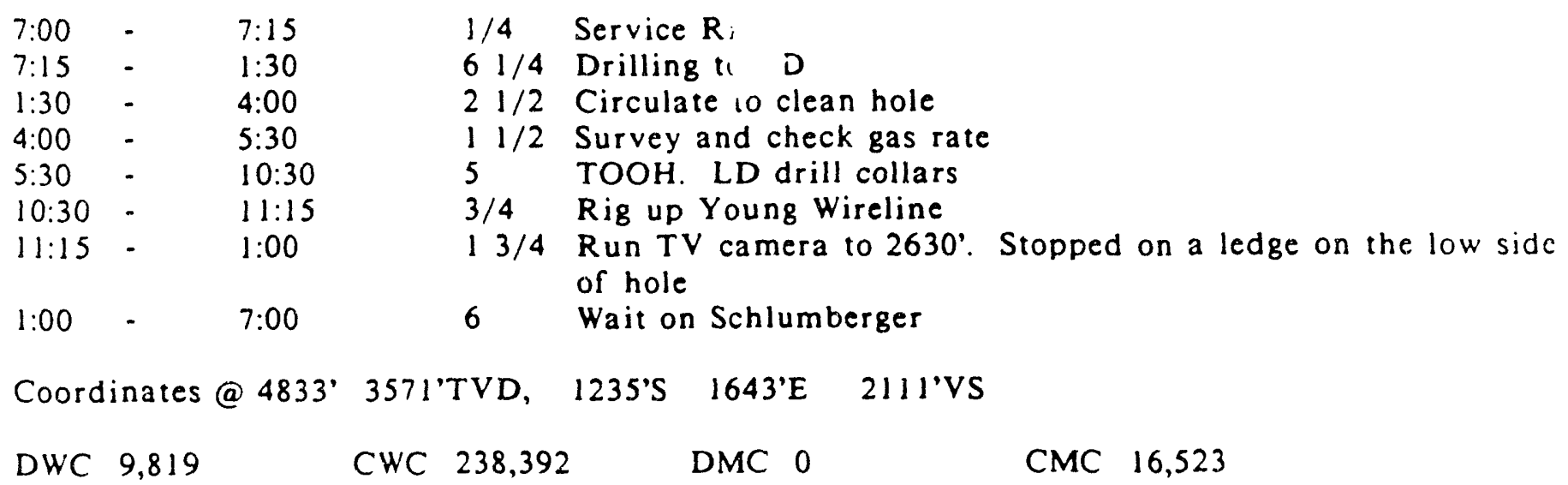


WELL NAME: Boggs \#1240 DEPTH:

FOOTAGE:

FORMATION:

ROTATING WEIGHT:
DATE: 8/1/89 REPORT TIME: 7:00 am ACTIVITY: Log $w / T V$ camera HLD: TORQUE:

DAY:

\section{BIT RECORD:}

Bit Size Type Manuf $\begin{gathered}\text { Serial } \\ \#\end{gathered}$

HLU:

Tyee Manue

AIR RATE:

MIST RATE:

BBLS/HR PRESSURE:

ADDITIVES:

BHA:

SURVEYS:

GAS: C1: $\quad$ C2: C3: C4: C5: , , C5: TOT:

SHOWS:

\section{TIME BREAKDOWN AND COMMENTS:}

FROM TO HRS

\begin{tabular}{|c|c|c|c|c|c|}
\hline 7:00 & - & $11: 30$ & & $41 / 2$ & Finish logging $w / 2 D T, N G T$ and induction \\
\hline $11: 30$ & - & 1:00 & & $11 / 2$ & Change logging tools \\
\hline 1:00 & - & $5: 00$ & & 4 & Log run \#7. Logges temperature log into hole \\
\hline $\begin{array}{l}5: 00 \\
0.15\end{array}$ & $\cdot$ & $9: 15$ & & $41 / 4$ & Log out of hole with SNP \\
\hline $9: 15$ & - & $11: 00$ & & $13 / 4$ & $\begin{array}{l}\text { Lay down logging tools. RD Schlumberger. } \\
\text { Rig up Young wireline }\end{array}$ \\
\hline $11: 00$ & - & 4:00 & & 5 & $\begin{array}{l}\text { TIH } 46 \text { std. Run TV camera to btm of drill pipe at } 2847 \text {. } \\
\text { Install side entry sub }\end{array}$ \\
\hline 4:00 & - & $7: 00$ & & 3 & Log run \#8. Logging $w / T V$ camera \\
\hline DWC & 4,900 & & CWC & 248,588 & CMC $\quad 16,523$ \\
\hline
\end{tabular}


WELL NAME: Boggs \#1240 DEPTH: 4833 FORMATION: FOOT AGE: 0
DATE: $8 / 2 / 89$

DAY:

\author{
ACTIVITY: Rig down Rotary Tools
HLD: \\ ACTIVITY: Rig down Rotary Tools
HLD: $\quad$ TORQUE:
}

HLU:

\section{BIT RECORD:}

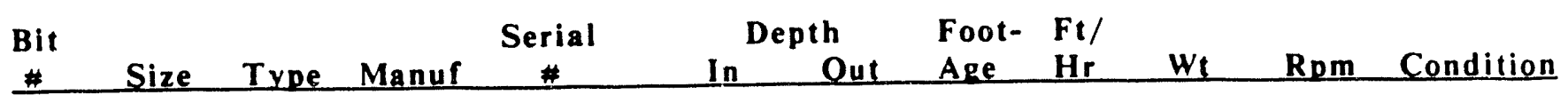
AIR RATE:
MIST RATE:
BBLS/HRPRESSURE:
ADDITIVES:
BHA:
SURVEYS:
GAS: C1: $\quad$ C2: $\quad$ C3: $\quad$ C4: C5: , C5+: , TOT:
SHOWS:
TIME BREAKDOWN AND COMMENTS:

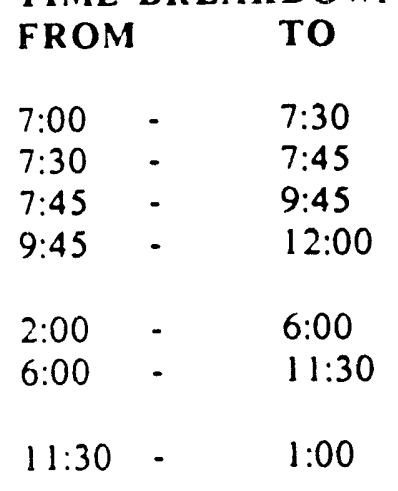
HRS $10 \%$ salt, $2 \% \mathrm{CaCl}_{2}, 10$ pps Kolite, $1 \% \mathrm{D} 60$,
$0.25 \% \mathrm{D} 46$, and $1 / 8 \mathrm{pps}$ poly flake. Mixed at $13.8 \mathrm{ppg}$ and $1.46 \mathrm{ft} 3 / \mathrm{sx}$. Displaced with 112 bbls fresh water. bumped
$1: 00 \quad-\quad 7: 00$
6 plug with 1380 psi. Float held ok. Plug down at 1:00 a m.
$1 / 2 \quad$ Log in with camera
$1 / 4 \quad$ Service rig
2 Log out of hole with TV camera
2 1/4 Pull camera out of drill pipe. Hung up going back inside pipe. Rig down wireline
6 Lay down drill pipe
$51 / 2$ Run 113 jts $51 / 2^{n}, 17 \#$, N-80, LT\&C casing.
Set at $4787^{\prime} \mathrm{KB}$. Run 60 rigid centralizers. One/joint
$11 / 2$ Cement with 2 bbls water, 40 bbls $3 \%$ gel water, 5 bbls water, 20 bbls $\mathrm{CN}-100,10 \mathrm{bbls}$ water, 605 sacks $50 / 50 \mathrm{poz} \mathrm{w} / 2 \% \mathrm{gcl}$,
DWC 110,530
CWC 359,118
DMC 0
CMC $\quad 16,523$ 
Appendix B

CASING TALLIES 


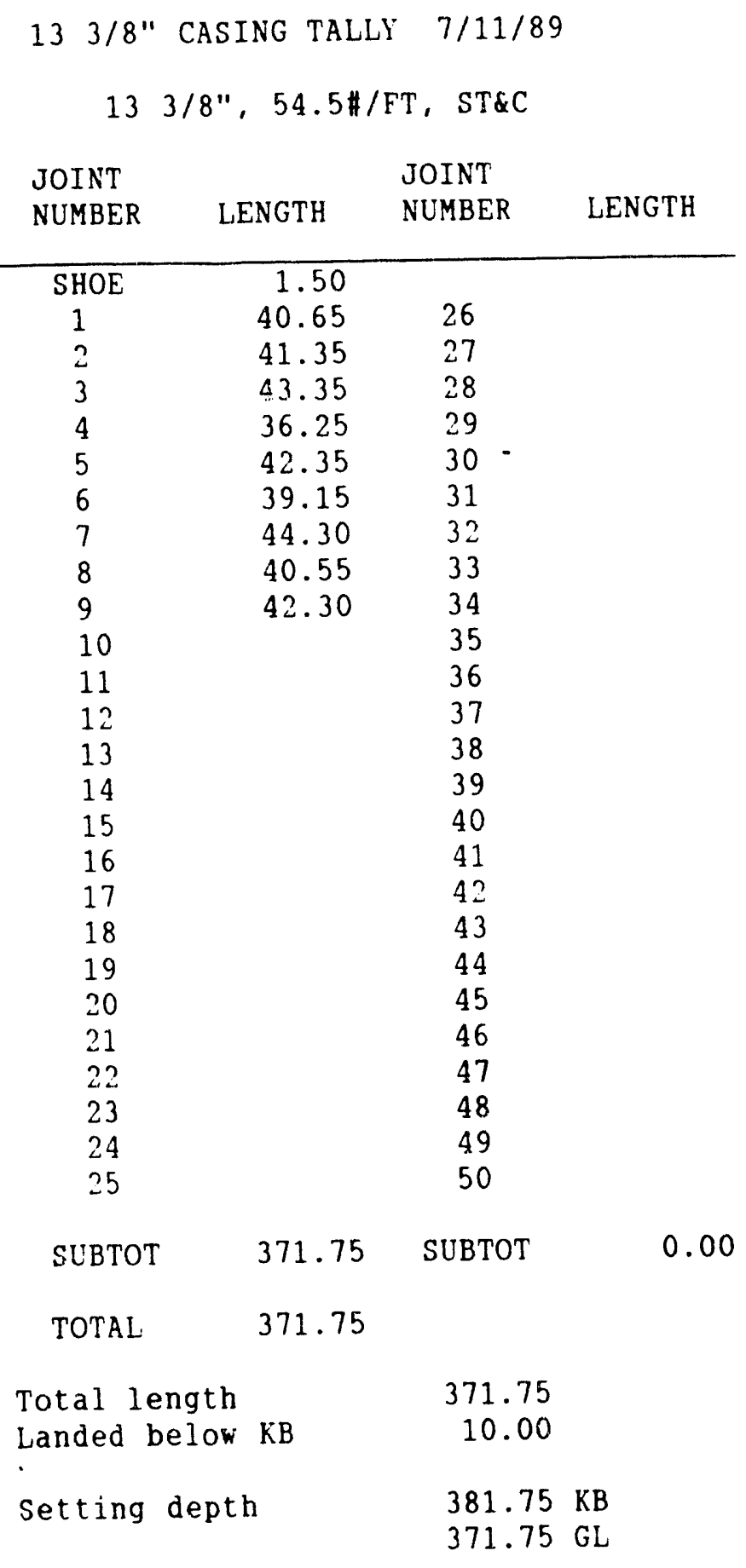


9 5/8" CASING TALLY 7/14/89

$95 / 8 ", 36 \# / \mathrm{FT}, J 55, \quad$ ST\&C

$\begin{array}{rll}\text { JOINT } & & \text { JOINT } \\ \text { NUMBER } & \text { LENGTH } & \text { NUMBER } \\ & & \text { LENGTH }\end{array}$

\begin{tabular}{|c|c|c|c|}
\hline SHOE & 1.00 & & \\
\hline 1 & 44.45 & 26 & 45.00 \\
\hline 2 & 43.95 & 27 & 43.35 \\
\hline 3 & 44.75 & 28 & 42.20 \\
\hline 4 & 44.90 & 29 & 45.05 \\
\hline 5 & 43.35 & 30 & 43.55 \\
\hline 6 & 43.60 & 31 & 45.20 \\
\hline 7 & 45.05 & 32 & 44.65 \\
\hline 8 & 44.70 & 33 & 43.50 \\
\hline 9 & 43.65 & 34 & 43.50 \\
\hline 10 & 44.70 & 35 & 43.60 \\
\hline 11 & 43.45 & 36 & 44.15 \\
\hline 12 & 44.90 & 37 & 44.50 \\
\hline 13 & 44.75 & 38 & 45.00 \\
\hline 14 & 44.85 & 39 & 43.55 \\
\hline 15 & 44.85 & 40 & 44.00 \\
\hline 16 & 40.40 & 41 & 43.40 \\
\hline 17 & 44.75 & 42 & 45.00 \\
\hline 18 & 44.75 & 43 & 43.45 \\
\hline 19 & 43.65 & 44 & 43.45 \\
\hline 20 & 44.70 & 45 & 44.80 \\
\hline 21 & 43.50 & 46 & 43.60 \\
\hline 22 & 44.85 & 47 & 44.75 \\
\hline 23 & 44.80 & 48 & 43.40 \\
\hline 24 & 43.45 & 49 & \\
\hline 25 & 36.25 & 50 & \\
\hline SUBTOT & 1098.00 & SUBTOT & 1012.65 \\
\hline TOTAL & 2110.65 & & \\
\hline \multirow{3}{*}{\multicolumn{2}{|c|}{$\begin{array}{l}\text { Total length } \\
3 \text { joints out } \\
\text { Landed below } \mathrm{KB}\end{array}$}} & 2110.65 & \\
\hline & & 131.75 & \\
\hline & & 10.00 & \\
\hline \multicolumn{2}{|c|}{ Setting depth } & 1988.90 & \\
\hline
\end{tabular}


CASING PALL? $51 / 2 ", 171,4-80$, LRT - RON 8/1/89

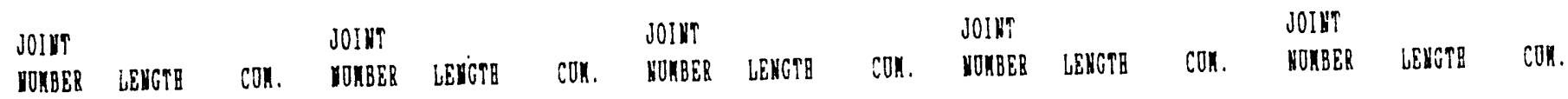

\begin{tabular}{|c|c|c|c|c|c|c|c|c|c|c|c|c|c|c|}
\hline $\begin{array}{c}\text { SBOE } \\
1\end{array}$ & $\begin{array}{r}0.92 \\
14.45\end{array}$ & $\begin{array}{r}0.9 ? \\
15.3 ?\end{array}$ & 26 & 42.15 & 1070.37 & 31 & 42.00 & 2092.32 & 76 & 42.30 & 3146.67 & $10 !$ & 42.15 & $4190.6 i$ \\
\hline $\begin{array}{l}1 \\
2\end{array}$ & $\begin{array}{l}14.45 \\
42.30\end{array}$ & $\begin{array}{l}15.3 ? \\
57.67\end{array}$ & 27 & 42.05 & 1112.42 & 52 & 42.05 & 2134.37 & $\eta ?$ & $4: .80$ & 3188.47 & 102 & 42.15 & 4232.77 \\
\hline 3 & 42.20 & 99.87 & 28 & 42.15 & $: 154.57$ & 53 & 42.20 & 2176.57 & 78 & 41.95 & 3250.42 & 103 & 42.35 & 4275.12 \\
\hline 4 & 42.15 & 142.02 & 29 & 42.15 & 1196.72 & 54 & 42.10 & 2218.67 & 79 & 42.20 & 3272.62 & 104 & $4 i .20$ & $430.3\}$ \\
\hline 9 & 42.35 & 184.37 & 30 & 42.20 & 1238.92 & 35 & 41.50 & 2260.17 & 80 & 42.15 & 3314.77 & 105 & 40.35 & 4357.67 \\
\hline 6 & 42.15 & 226.52 & 31 & 42.15 & 1281.07 & 56 & 42.00 & 2302.17 & $8 i$ & 42.40 & 3357.17 & 106 & 42.25 & 4399.82 \\
\hline 1 & 42.20 & 268.72 & 32 & 42.20 & 1323.27 & 57 & 42.05 & 2344.22 & $8 i$ & 42.20 & 3399.37 & $: 07$ & 42.35 & $444: .1 ?$ \\
\hline 8 & 42.30 & 311.02 & 33 & 42.15 & 1365.42 & 58 & 42.35 & $2386.5 ?$ & 83 & 41.90 & 3441.27 & 108 & $4 \% .20$ & $4484.3 ?$ \\
\hline 9 & 42.25 & 353.27 & 34 & 42.20 & 1407.62 & 59 & $4 i .15$ & 2428.72 & 84 & 42.35 & 3483.62 & 109 & 42.20 & 4526.57 \\
\hline 10 & 42.40 & 395.67 & 35 & 42.15 & 1449.77 & 60 & 42.25 & 2470.97 & 85 & 41.95 & $3525.5 ?$ & $: 10$ & 42.15 & 4568.72 \\
\hline 11 & 42.30 & 437.97 & 36 & 42.10 & 1491.87 & $\varepsilon_{i}$ & 42.35 & 2513.32 & 86 & 42.35 & 3567.92 & ii: & 42.25 & 4610.97 \\
\hline 12 & 42.25 & 480.22 & 37 & 42.15 & 1534.02 & 62 & 42.20 & 2555.52 & 87 & 34.10 & 3602.02 & 112 & 42.15 & 4653.12 \\
\hline 13 & 42.25 & 522.47 & 38 & 42.15 & 1576.17 & 63 & 41.35 & 2596.87 & 88 & 42.20 & 3644.22 & 113 & 42.00 & 4695.12 \\
\hline 14 & 42.10 & $564.5 ?$ & 39 & 42.15 & 1618.32 & 64 & 42.20 & 2639.07 & 89 & 42.20 & 3686.42 & 114 & 42.15 & $4 ? 3^{*} .2 ?$ \\
\hline 15 & 42.25 & 606.82 & 40 & 41.75 & 1660.07 & 65 & 41.75 & 2680.82 & 90 & 42.20 & 3728.62 & 115 & 41.90 & 4779.17 \\
\hline 16 & 42.25 & 649.07 & $4 !$ & 42.15 & 1702.22 & 66 & 42.30 & 2723.12 & 91 & 42.20 & 3770.82 & 116 & $4: .90$ & 4821.07 out \\
\hline $1 ?$ & 42.05 & 691.12 & 42 & 42.15 & $: 744.37$ & 67 & 42.45 & 2765.57 & 92 & 42.25 & 3812.97 & :i? & 42.00 & 4863.07 out \\
\hline 18 & 42.15 & 733.27 & 43 & 14.60 & 1758.97 & 68 & 42.40 & 2807.97 & 93 & 42.20 & 3855.27 & i18 & 42.20 & 4905.27 obt \\
\hline$\therefore 9$ & 42.05 & 775.32 & 44 & 42.15 & 1801.12 & 69 & 42.40 & 2850.37 & 94 & 42.20 & $3897.3 ?$ & $: 19$ & 41.75 & 4947.02 ous: \\
\hline 20 & 42.05 & 817.37 & 45 & 42.10 & 1843.22 & 70 & 42.15 & 2892.52 & 95 & 42.30 & $3939.6 ?$ & 126 & & \\
\hline 21 & 42.10 & 859.47 & 46 & 42.10 & 1885.32 & 71 & 42.35 & 2934.87 & 96 & 42.20 & $398 \div .87$ & 121 & & \\
\hline 22 & 42.30 & 901.77 & 47 & 42.15 & $1927.4 ?$ & 72 & 42.20 & 2977.07 & 07 & 42.20 & 4024.07 & $i 22$ & & \\
\hline 23 & 42.20 & $943.9 ?$ & 48 & 42.05 & 1969.52 & 73 & 42.40 & 3019.47 & 98 & 40.10 & 4064.17 & 123 & & \\
\hline 24 & 42.10 & 986.07 & 49 & 42.15 & 2011.67 & 74 & 42.40 & 3061.87 & 99 & 42.15 & 4106.32 & 124 & & \\
\hline 25 & $\{2.25$ & $1028 . \hat{2}$ & 50 & 38.65 & 3050.32 & 75 & 42.50 & 3104.37 & 100 & $4 \ldots .15$ & 4148.47 & 125 & & \\
\hline \multirow[t]{6}{*}{ sub? } & 1028.22 & & SOBPOP? & 1022.10 & & SUBMCO? & 1054.05 & & SOBTOR & 1044.10 & & sogmar. & $998 . \vdots \vdots$ & \\
\hline & POPAL & 4947.02 & & & & & & & & & & & & \\
\hline & \multirow{3}{*}{\multicolumn{2}{|c|}{$\begin{array}{l}\text { Potal leagtb } \\
4 \text { joints out } \\
\text { Landed belon } 8 B\end{array}$}} & 4947.02 & & & & & & & & & & & \\
\hline & & & 157.85 & & & & & & & & & & & \\
\hline & & & 8.00 & & & & & & & & & & & \\
\hline & \multicolumn{2}{|c|}{ Settiog depth } & 4787.17 & & & & & & & & & & & \\
\hline
\end{tabular}


Appendix C

DRILL PIPE TALLIES 
DRTLL PIPE TALLY JOGING RUN \#6 7/31/89

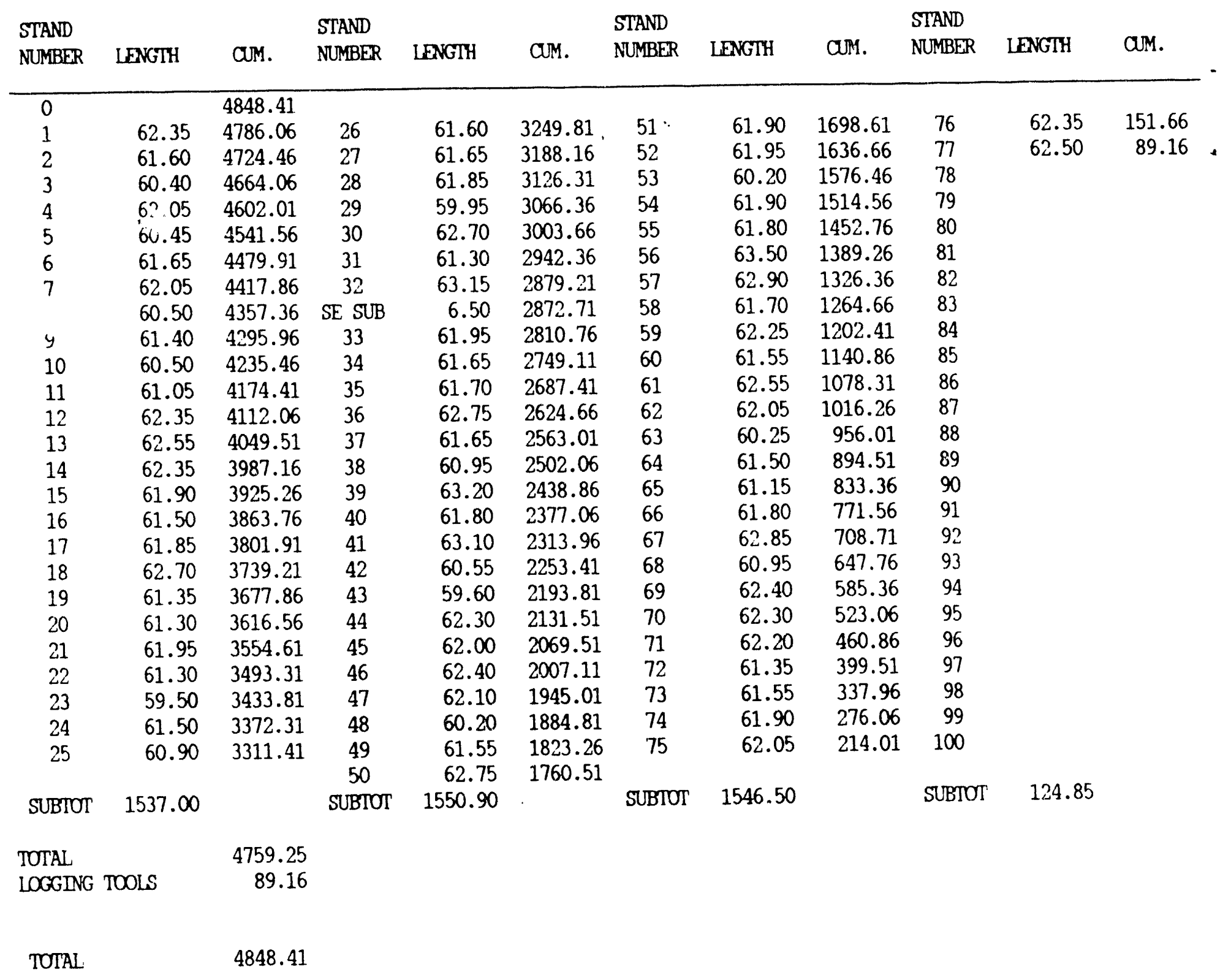


DRILL PIPE TALLY - LOGGENG RUN \#7 7/31/89

STAND STAND STAND STAND NUMBER LENGTH CUM. NUMBER LENGTH COM. NUMBER LENGTH CUM. NUMBER LENGTH CUM.

\begin{tabular}{lrrrrrrrrrrr}
\hline 0 & 62.35 & 4690.40 & 26 & 61.60 & 3154.15 & 51 & 61.90 & 1609.45 & 76 & 62.35 & 62.50 \\
1 & 61.60 & 4628.80 & 27 & 61.65 & 3092.50 & 52 & 61.95 & 1547.50 & 77 & 62.50 & 0.00 \\
2 & 60.40 & 4568.40 & 28 & 61.85 & 3030.65 & 53 & 60.20 & 1487.30 & 78 & \\
3 & 62.05 & 4506.35 & 29 & 59.95 & 2970.70 & 54 & 61.90 & 1425.40 & 79 & \\
4 & 60.45 & 4445.90 & 30 & 62.70 & 2908.00 & 55 & 61.80 & 1363.60 & 80 & \\
5 & 61.65 & 4384.25 & 31 & 61.30 & 2846.70 & 56 & 63.50 & 1300.10 & 81 & \\
6 & 62.05 & 4322.20 & 32 & 63.15 & 2783.55 & 57 & 62.90 & 1237.20 & 82 & \\
7 & 60.50 & 4261.70 & SE SUB & 0.00 & 2783.55 & 58 & 61.70 & 1175.50 & 83 & \\
8 & 61.40 & 4200.30 & 33 & 61.95 & 2721.60 & 59 & 62.25 & 1113.25 & 84 & \\
9 & 60.50 & 4139.80 & 34 & 61.65 & 2659.95 & 60 & 61.55 & 1051.70 & 85 & \\
10 & 61.05 & 4078.75 & 35 & 61.70 & 2598.25 & 61 & 62.55 & 989.15 & 86 & \\
11 & 62.35 & 4016.40 & 36 & 62.75 & 2535.50 & 62 & 62.05 & 927.10 & 87 & \\
12 & 62.55 & 3953.85 & 37 & 61.65 & 2473.85 & 63 & 60.25 & 866.85 & 88 & \\
13 & 62.35 & 3891.50 & 38 & 60.95 & 2412.90 & 64 & 61.50 & 805.35 & 89 & \\
14 & 61.90 & 3829.60 & 39 & 63.20 & 2349.70 & 65 & 61.15 & 744.20 & 90 & \\
15 & 61.50 & 3768.10 & 40 & 61.80 & 2287.90 & 66 & 61.80 & 682.40 & 91 & \\
16 & 61.85 & 3706.25 & 41 & 63.10 & 2224.80 & 67 & 62.85 & 619.55 & 92 & \\
17 & 62.70 & 3643.55 & 42 & 60.55 & 2164.25 & 68 & 60.95 & 558.60 & 93 & \\
18 & 61.35 & 3582.20 & 43 & 59.60 & 2104.65 & 69 & 62.40 & 496.20 & 94 & \\
19 & 61.30 & 3520.90 & 44 & 62.30 & 2042.35 & 70 & 62.30 & 433.90 & 95 & \\
20 & 61.95 & 3458.95 & 45 & 62.00 & 1980.35 & 71 & 62.20 & 371.70 & 96 & \\
21 & 61.30 & 3397.65 & 46 & 62.40 & 1917.95 & 72 & 61.35 & 310.35 & 97 & \\
22 & 59.50 & 3338.15 & 47 & 62.10 & 1855.85 & 73 & 61.55 & 248.80 & 98 & \\
23 & 61.50 & 3276.65 & 48 & 60.20 & 1795.65 & 74 & 61.90 & 186.90 & 99 & \\
24 & 60.90 & 3215.75 & 49 & 61.55 & 1734.10 & 75 & 62.05 & 124.85 & 100 & \\
25 & & 50 & 62.75 & 1671.35 & & & & & \\
SUBTOT & 1537.00 & & SUBTOT & 1544.40 & & SUBTOT & 1546.50 & & SUBTOT & 124.85 \\
& & & & & & & & & & \\
TOTAL & & 4752.75 & & & & & & & & \\
LOGING TOOLS & 0.00 & & & & & & & & \\
& & & & & & & & & &
\end{tabular}

TOTAL

4752.75 
DRILU PIPE TALLY - LOGGING RUN \#8 8/1/89

\begin{tabular}{|c|c|c|c|c|c|c|c|c|c|c|c|}
\hline $\begin{array}{l}\text { STAND } \\
\text { NUMBER }\end{array}$ & LENGTH & COM. & $\begin{array}{l}\text { STAND } \\
\text { NUMBER }\end{array}$ & LENGTH & am. & $\begin{array}{l}\text { STAND } \\
\text { NUMBER }\end{array}$ & LENGTH & aM. & $\begin{array}{l}\text { STAND } \\
\text { NUMBER }\end{array}$ & LENGTH & CMM. \\
\hline 1 & 62.50 & 62.50 & 26 & 61.95 & 1609.45 & 51 & 61.65 & 3160.65 & 76 & 61.60 & 4696.90 \\
\hline 2 & 62.35 & 124.85 & 27 & 61.90 & 1671.35 & 52 & 61.60 & 3222.25 & 77 & 62.35 & 4759.25 \\
\hline 3 & 62.05 & 186.90 & 28 & 62.75 & 1734.10 & 53 & 60.90 & 3283.15 & 78 & & \\
\hline 4 & 61.90 & 248.80 & 29 & 61.55 & 1795.65 & 54 & 61.50 & 3344.65 & 79 & & \\
\hline 5 & 61.55 & 310.35 & 30 & 60.20 & 1855.85 & 55 & 59.50 & 3404.15 & 80 & & \\
\hline 6 & 61.35 & 371.70 & 31 & 62.10 & 1917.95 & 56 & 61.30 & 3465.45 & 81 & & \\
\hline 7 & 62.20 & 433.90 & 32 & 62.40 & 1980.35 & 57 & 61.95 & 3527.40 & 82 & & \\
\hline 8 & 62.30 & 496.20 & 33 & 62.00 & 2042.35 & 58 & 61.30 & 3588.70 & 83 & & \\
\hline 9 & 62.40 & 558.60 & 34 & 62.30 & 2104.65 & 59 & 61.35 & 3650.05 & 84 & & \\
\hline 10 & 60.95 & 619.55 & 35 & 59.60 & 2164.25 & 60 & 62.70 & 3712.75 & 85 & & \\
\hline 11 & 62.85 & 682.40 & 36 & 60.55 & 2224.80 & 61 & 61.85 & 3774.60 & 86 & & \\
\hline 12 & 61.80 & 744.20 & 37 & 63.10 & 2287.90 & 62 & 61.50 & 3836.10 & 87 & & \\
\hline 13 & 61.15 & 805.35 & 38 & 61.80 & 2349.70 & 63 & 61.90 & 3898.00 & 88 & & \\
\hline 14 & 61.50 & 866.85 & 39 & 63.20 & 2412.90 & 64 & 62.35 & 3960.35 & 89 & & \\
\hline 15 & 60.25 & 927.10 & 40 & 60.95 & 2473.85 & 65 & 62.55 & 4022.90 & 90 & & \\
\hline 16 & 62.05 & 989.15 & 41 & 61.65 & 2535.50 & 66 & 62.35 & 4085.25 & 91 & & \\
\hline 17 & 62.55 & 1051.70 & 42 & 62.75 & 2598.25 & 67 & 61.05 & 4146.30 & 92 & & \\
\hline 18 & 61.55 & 1113.25 & 43 & 61.70 & 2659.95 & 68 & 60.50 & 4206.80 & 93 & & \\
\hline 19 & 62.25 & 1175.50 & 44 & 61.65 & 2721.60 & 69 & 61.40 & 4268.20 & 94 & & \\
\hline 20 & 61.70 & 1237.20 & 45 & 61.95 & 2783.55 & 70 & 60.50 & 4328.70 & 95 & & \\
\hline 21 & 62.90 & 1300.10 & 46 & 63.15 & 2846.70 & 71 & 62.05 & 4390.75 & 96 & & \\
\hline 22 & 63.50 & 1363.60 & SE SUB & 6.50 & 2853.20 & 72 & 61.65 & 4452.40 & 97 & & \\
\hline 23 & 61.80 & 1425.40 & 47 & 61.30 & 2914.50 & 73 & 60.45 & 4512.85 & 98 & & \\
\hline 24 & 61.90 & 1487.30 & 48 & 62.70 & 2977.20 & 74 & 62.05 & 4574.90 & 99 & & \\
\hline 25 & 60.20 & 1547.50 & $\begin{array}{l}49 \\
50\end{array}$ & $\begin{array}{l}59.95 \\
61.85\end{array}$ & $\begin{array}{l}3037.15 \\
3099.00\end{array}$ & 75 & 60.40 & 4635.30 & 100 & & \\
\hline SUBTOT & 1547.50 & & SUBTOT & 1551.50 & & SUBTOT & 1536.30 & & SUBIOT & 123.95 & \\
\hline \multirow{2}{*}{\multicolumn{2}{|c|}{$\begin{array}{l}\text { TOTAL } \\
\text { LOGGING TOOLS }\end{array}$}} & 4759.25 & & & & & & & & & \\
\hline & & 0.00 & & & & & & & & & \\
\hline TAL & & 4759.25 & & & & & & & & & \\
\hline
\end{tabular}

LOGGED FROM TOP DOWN WITH VIDEO CAMERA 
Appendix D

MOTOR PERFORMANCE AND BOTTOM HOLE ASSEMBLIES 
The first motor to be run was the Eastman double bend, Mach I with two stabilizers. The motor drilled from $2150^{\prime}$ to $2362^{\prime}\left(212^{\prime}\right)$ in 20 hours and was pulled because of low penetration rate. The average penetration rate was $10.6 \mathrm{ft} / \mathrm{hr}$ with a low of 3 $\mathrm{ft} / \mathrm{hr}$ and a high of $20 \mathrm{ft} / \mathrm{hr}$. Originally, it was thought that there was a problem with the motor or the bit, but the low penetration rate was caused by siltstone stringers in the formation.

For a period of time, the Eastman motor was run at $1600 \mathrm{scfm}$ with 25 barrels per hour (BPH) of mist. The rig's mist pump was not capable of pumping less than 25 $\mathrm{BPH}$ at the required pressure. The standpipe pressure while pumping $25 \mathrm{BPH}$ was approximately 800 psi. A replacement pump was rigged up and the mist rate dropped to $10 \mathrm{BPH}$. The standpipe pressure fell to approximately $600 \mathrm{psi}$ with the same air volume.

The equivalent flow rate through the motor while drilling was 340 gallons per minute. There were no problems running the motor and Eastman indicated that no repairs were necessary. The motor was functioning properly when pulled.

The averaged dogleg severity generated by the Eastman motor was $10.50 / 100$. The system was designed to build at $8.6^{\circ} / 100^{\prime}$. Because of the higher than anticipated build rate, the Baker motor was run next.

The Baker bent housing motor had the bend in the motor set at 2 degrees. The motor drilled from $2362^{\prime}$ to $2548^{\prime}\left(186^{\prime}\right)$ in 19 hours and was pulled because of low penetration rate. The average penetraticn rate was $9.8 \mathrm{ft} / \mathrm{hr}$ with a low of $2 \mathrm{ft} / \mathrm{hr}$ and a high of $20 \mathrm{ft} / \mathrm{hr}$. Again, the low penetration rate was due to formation effects.

The motor was run with a little over $1600 \mathrm{scfm}$ and $10 \mathrm{BPH}$ of mist. The equivalent flow rate through the motor was calculated to be $346 \mathrm{gpm}$. No problems were experienced in running the motor and the motor was still functioning properly when it was pulled. The Baker bent housing motor created an average dogleg severity of $9.50 / 100$ '. A longer tangent section was planned to compensate for the higher build rate.

The third motor run was made with the same Baker bent housing motor with the bend set a 2 degrees. The motor drilled from $2811^{\prime}$ to $3165^{\prime}\left(354^{\prime}\right)$ in 19.5 hours. The average penetration rate was $18.2 \mathrm{ft} / \mathrm{hr}$. There was only one short section that drilled $\mathrm{a}$ iess than $3 \mathrm{ft} / \mathrm{hr}$. The rest $\mathrm{nf}$ the motor run drilled at approximately 20 $\mathrm{ft} / \mathrm{hr}$. The motor was pulled because the build section had been completed. There were no problems running the motor and the motor was functioning properly when pulled.

The fourth motor run was made to make a direction change in the slant section of the hole. Again, the same Baker motor was run with the bend set at 2 degrees. The motor drilled from $3785^{\prime}$ to $3855^{\prime}\left(70^{\prime}\right)$ in four hours. The average penetration rate was $17.5 \mathrm{ft} / \mathrm{hr}$. The motor was pulled because the hole had unexpectedly started dropping inclination. The flow rate through the motor was $1400 \mathrm{scfm}$ and $15 \mathrm{BPH}$ of mist. The mist rate had been increased to aid in hole cleaning. The standpipe pressure was $470 \mathrm{psi}$ and the equivalent flow rate through the motor was $305 \mathrm{gpm}$.

No problems were encountered in running either the Eastman or the Baker motors. The motors started shortly after the air was turned into the drill pipe even after 
connections. The motors did stall several times but it was due to excess weight being placed on the motor. A maximum weight of $12,000 \mathrm{lbs}$ was run on the motors while drilling the harder siltstones at less than four feet per hour. The maximum weight that could be run on the motors while drilling shale at $20 \mathrm{ft} / \mathrm{hr}$ was approximately $6,000 \mathrm{lbs}$ before the motor would stall.

Neither the Baker motor nor the Eastman motor showed any excessive wear when torn down and inspected. The Eastman motor drilled for 20 hours and the Baker motor drilled for a total of $\mathbf{4 2 . 5}$ hours in three runs. The Baker motor also had an additional 11.25 hours circulating off bottom to clean the hole. Most of that time (8.75 hours) was at the end of the last run in the slant section. Total hours (circulating and drilling) on the Baker motor was 53.75 hours.

Running the motors on high pressure air definitely increased motor life. No motor failures were experienced even circulating for long periods of time off bottom. No rig time was spent tripping failed motors or trying to restart a motor after a connection. The savings in rig time more than offset the additional cost associated with renting the high pressure air package.

One directional, rotary assembly was used to drill the Boggs \#1240. The assembly consisted of a bit, float sub, six point reamer, and two nonmagnetic drill collars. The float sub was run below the six point on BHA number 4 and 9 , and above the six point on BHA number 6 and 7. Other than that, the bottomhole assemblies were the same. Each assembly is listed in Appendix $\mathbf{E}$.

The tangent section was drilled with the bottomhole assembly that was planned to be used in the slant section. The intention was to collect data that could be used to fine tune the assembly for the slant section and to compensate for bit walk.

Bottomhole assembly number four drilled the tangent section from $2548^{\prime}$ to $2811^{\prime}$ $\left(263^{\prime}\right)$. The average penetration rate was $45.7 \mathrm{ft} / \mathrm{hr}$ with $25,000 \mathrm{lbs}$ of bit weight and $80 \mathrm{rpm}$. The assembly built $1.34 \% / 100^{\prime}$ and walked $0.30 \% / 100^{\prime}$ to the right as calculated from the surveys between $2553^{\prime}$ and $2799^{\prime}$.

The planned build rate in the slant section was $0.5^{\circ} / 100$. It was assumed that the assembly would build slower at the higher inclinations in the slant section but not as slow as $0.5^{\circ} / 100^{\prime}$. Therefore, the float sub was also moved to the top of the six point to reduce the building tendency.

The Eastman "Predict" program indicated that assembly would still build inclination at approximately $0.75 \% / 100^{\prime}$. To compensate for the higher build rate, the build section was stopped at $68^{\circ}$ instead of the planned $71^{\circ}$.

Bottomhole assembly number six twisted off while reaming the motor-drilled hole. Bottomhole assembly number seven (with the float sub above the six point) drilled from $3165^{\prime}$ to $3785^{\prime}\left(620^{\prime}\right)$. The average penetration rate was $33.5 \mathrm{ft} / \mathrm{hr}$ with 20,000 lbs bit weight and $70 \mathrm{rpm}$. The assembly was pulled because it was walking to the left and the well would have ended up too close to the lease line. A motor was run to turn the well back to the right. 
The rotary assembly built inclination at a rate of $0.85^{\circ} / 100^{\prime}$ and walked $1.000 / 100^{\prime}$ to the left. The build rate was close to the predicted value; however, the bit walked in the opposite direction of that predicted in the tangent section.

Bottomhole assembly number nine was run after the motor run. The motor had unexpectedly dropped inclination so the float sub was placed below the six point to increase build tendency. The assembly drilled from $3855^{\prime}$ to $4833^{\prime}(978)$. The average penetration rate was $29.0 \mathrm{ft} / \mathrm{hr}$ with $20,000 \mathrm{lbs}$ bit weight and $60-70 \mathrm{rpm}$.

The assembly built inclination at a rate of $0.45^{\circ} / 100^{\prime}$ and walked $0.890 / 100^{\prime}$ to the left. Apparently, the float sub below the bit actually slowed the build rate. Build and walk rates for each assembly can be found in Appendix F. 
Appendix E

BOTTOM HOLE ASSEMBLY DATA 


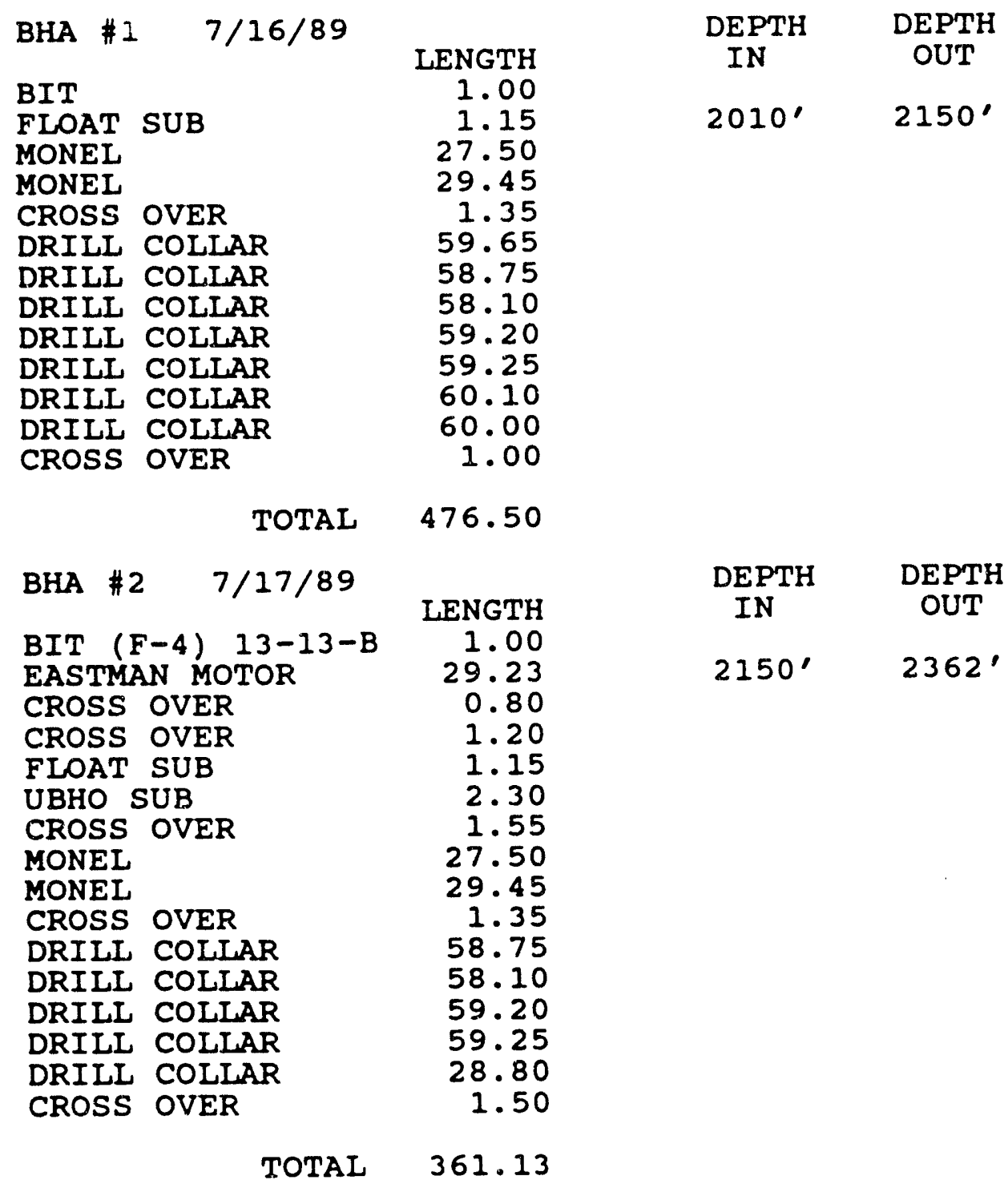




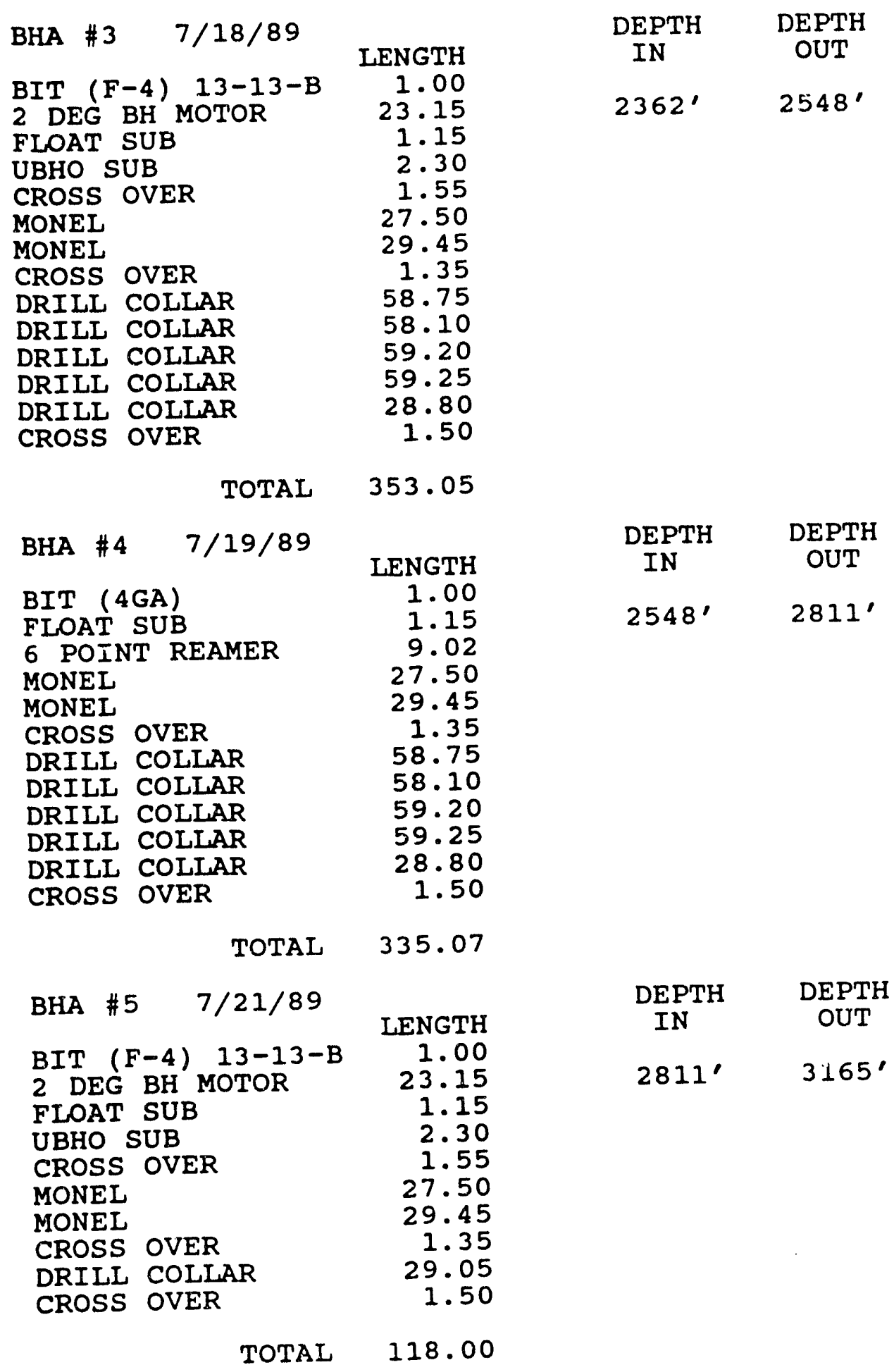




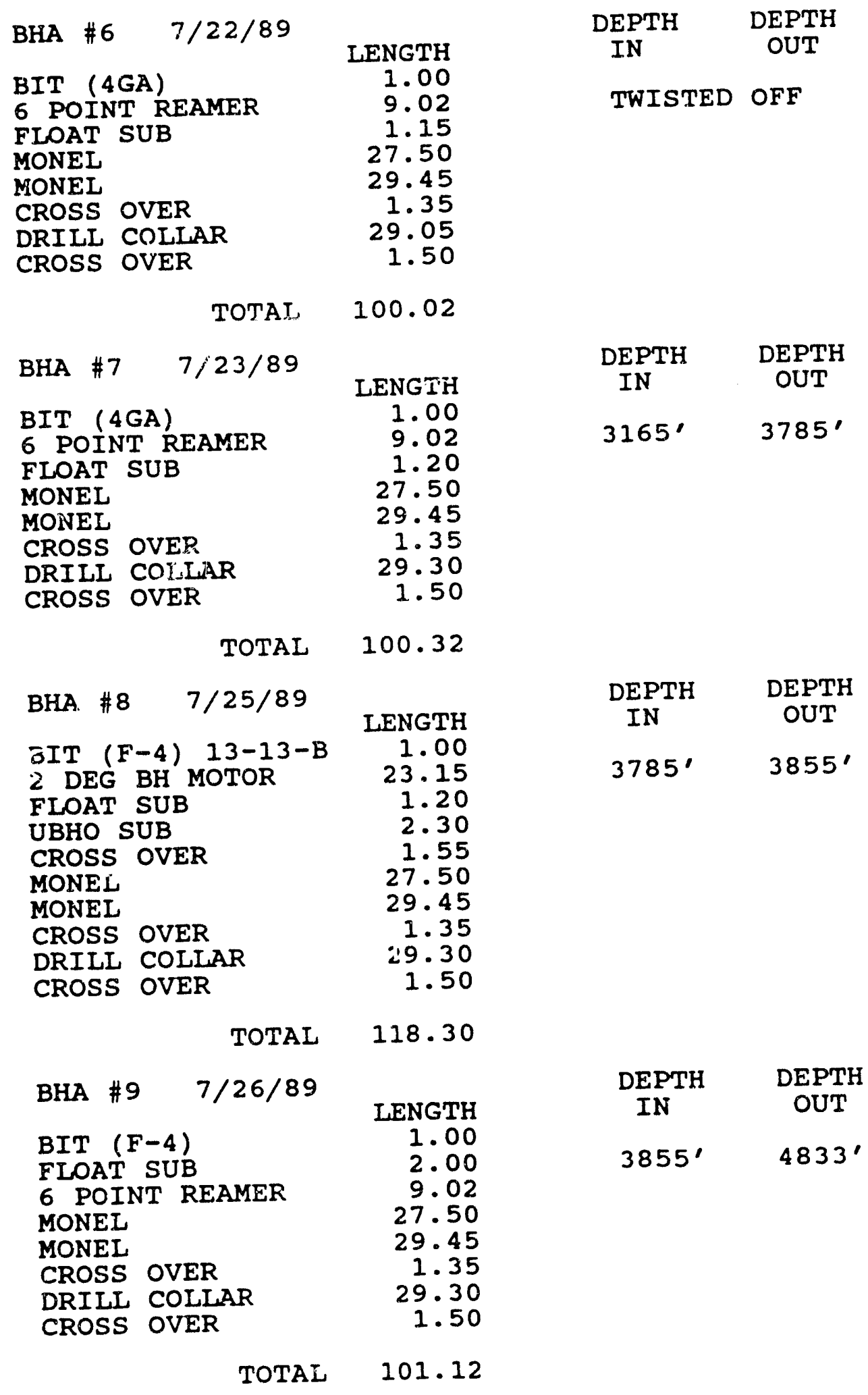


Appendix F

BUILD AND WALK RATE DATA 


\begin{tabular}{|c|c|c|c|c|c|c|}
\hline $\begin{array}{l}\text { EASURED } \\
\text { DEPTH } \\
\text { FEET }\end{array}$ & $\begin{array}{c}\text { DRIFT } \\
\text { ANGLE } \\
\text { DEGREES }\end{array}$ & $\begin{array}{c}\text { DRIFT } \\
\text { AZIMUTH } \\
\text { DEGREES }\end{array}$ & $\begin{array}{c}\text { COURSE } \\
\text { LENGTH } \\
\text { FEET }\end{array}$ & $\begin{array}{c}\text { BUILD } \\
\text { RATE } \\
\text { DEG/100 }\end{array}$ & $\begin{array}{c}\text { WALK } \\
\text { RATE } \\
\text { DEG/100 }\end{array}$ & $\begin{array}{l}\text { BOTTOMHOLE } \\
\text { ASSEMBLY }\end{array}$ \\
\hline $\begin{array}{l}0.00 \\
2097.00 \\
2128.00 \\
2160.00 \\
2190.00\end{array}$ & $\begin{array}{l}0.00 \\
1.00 \\
1.30 \\
3.20 \\
6.30\end{array}$ & $\begin{array}{r}60.00 \\
60.00 \\
104.75 \\
104.75 \\
109.75\end{array}$ & $\begin{array}{r}0.00 \\
2097.00 \\
31.00 \\
32.00 \\
30.00\end{array}$ & $\begin{array}{r}0.00 \\
0.05 \\
0.97 \\
5.94 \\
10.33\end{array}$ & $\begin{array}{r}0.00 \\
0.00 \\
144.35 \\
0.00 \\
16.67\end{array}$ & $\begin{array}{l}\text { ROTARY } \\
\text { ROTARY } \\
\text { ROTARY AND EASTMAN MOTOI } \\
\text { EASTMAN MOTOR }\end{array}$ \\
\hline $\begin{array}{l}2220.00 \\
2251.00 \\
2282.00 \\
2304.00 \\
2348.00\end{array}$ & $\begin{array}{r}9.80 \\
13.20 \\
16.30 \\
18.40 \\
22.70\end{array}$ & $\begin{array}{l}109.75 \\
109.75 \\
113.75 \\
114.75 \\
117.75\end{array}$ & $\begin{array}{l}30.00 \\
31.00 \\
31.00 \\
22.00 \\
44.00\end{array}$ & $\begin{array}{r}11.67 \\
10.97 \\
10.00 \\
9.55 \\
9.77\end{array}$ & $\begin{array}{r}0.00 \\
0.00 \\
12.90 \\
4.55 \\
6.82\end{array}$ & $\begin{array}{ll}\text { EASTMAN } & \text { MOTOR } \\
\text { EASTMAN } & \text { MOTOR } \\
\text { EASTMAN } & \text { MOTOR } \\
\text { EASTMAN } & \text { MOTOR } \\
\text { EASTMAN } & \text { MOTOR }\end{array}$ \\
\hline $\begin{array}{l}2378.00 \\
2411.00 \\
2440.00 \\
2471.00 \\
2490.00\end{array}$ & $\begin{array}{l}25.00 \\
27.30 \\
28.50 \\
30.90 \\
33.50\end{array}$ & $\begin{array}{l}121.75 \\
126.75 \\
132.75 \\
134.75 \\
133.75\end{array}$ & $\begin{array}{l}30.00 \\
33.00 \\
29.00 \\
31.00 \\
19.00\end{array}$ & $\begin{array}{r}7.67 \\
6.97 \\
4.14 \\
7.74 \\
13.68\end{array}$ & $\begin{array}{r}13.33 \\
15.15 \\
20.69 \\
6.45 \\
-5.26\end{array}$ & $\begin{array}{l}\text { EASTMAN AND BAKER MOTOR } \\
\text { BAKER MOTOR } \\
\text { BAKER MOTOR } \\
\text { BAKER MOTOR } \\
\text { BAKER MOTOR }\end{array}$ \\
\hline $\begin{array}{l}2553.00 \\
2615.00 \\
2677.00 \\
2738.00 \\
2799.00\end{array}$ & $\begin{array}{l}32.50 \\
32.75 \\
33.75 \\
35.00 \\
35.80\end{array}$ & $\begin{array}{l}134.00 \\
133.00 \\
133.00 \\
134.00 \\
134.75\end{array}$ & $\begin{array}{l}63.00 \\
62.00 \\
62.00 \\
61.00 \\
61.00\end{array}$ & $\begin{array}{r}-1.59 \\
0.40 \\
1.61 \\
2.05 \\
1.31\end{array}$ & $\begin{array}{r}0.40 \\
-1.61 \\
0.00 \\
1.64 \\
1.23\end{array}$ & $\begin{array}{l}\text { BAKER MOTOR AND ROTARY } \\
\text { ROTARY } \\
\text { ROTARY } \\
\text { ROTARY } \\
\text { ROTARY }\end{array}$ \\
\hline $\begin{array}{l}2830.00 \\
2861.00 \\
2890.00 \\
2921.00 \\
2950.00\end{array}$ & $\begin{array}{l}37.00 \\
39.80 \\
42.00 \\
44.80 \\
47.40\end{array}$ & $\begin{array}{l}133 \cdot 75 \\
134 \cdot 75 \\
133.75 \\
133.75 \\
132.75\end{array}$ & $\begin{array}{l}31.00 \\
31.00 \\
29.00 \\
31.00 \\
29.00\end{array}$ & $\begin{array}{l}3.87 \\
9.03 \\
7.59 \\
9.03 \\
8.97\end{array}$ & $\begin{array}{r}-3.23 \\
3.23 \\
-3.45 \\
0.00 \\
-3.45\end{array}$ & $\begin{array}{l}\text { ROTARY AND BAKER MOTOR } \\
\text { BAKER MOTOR } \\
\text { BAKER MOTOR } \\
\text { BAKER MOTOR } \\
\text { BAKER MOTOR }\end{array}$ \\
\hline $\begin{array}{l}3012.00 \\
3074.00 \\
3187.00 \\
3249.00 \\
3310.00\end{array}$ & $\begin{array}{l}53.00 \\
58.90 \\
67.25 \\
68.00 \\
68.50\end{array}$ & $\begin{array}{l}130.75 \\
132.00 \\
132.00 \\
132.00 \\
132.00\end{array}$ & $\begin{array}{r}62.00 \\
62.00 \\
113.00 \\
62.00 \\
61.00\end{array}$ & $\begin{array}{l}9.03 \\
9.52 \\
7.39 \\
1.21 \\
0.82\end{array}$ & $\begin{array}{r}-3.23 \\
2.02 \\
0.00 \\
0.00 \\
0.00\end{array}$ & $\begin{array}{l}\text { BAYER MOTOR } \\
\text { BA :R MOTOR } \\
\text { BAKER MOTOR AND ROTARY } \\
\text { ROTARY } \\
\text { ROTARY }\end{array}$ \\
\hline $\begin{array}{l}3497.00 \\
3620.00 \\
3744.00 \\
3751.00 \\
3804.00\end{array}$ & $\begin{array}{l}70.00 \\
71.50 \\
72.00 \\
72.20 \\
69.40\end{array}$ & $\begin{array}{l}130.00 \\
128.00 \\
127.00 \\
127.00 \\
129.00\end{array}$ & $\begin{array}{r}187.00 \\
123.00 \\
124.00 \\
7.00 \\
53.00\end{array}$ & $\begin{array}{r}0.80 \\
1.22 \\
0.40 \\
2.86 \\
-5.28\end{array}$ & $\begin{array}{r}-1.07 \\
-1.63 \\
-0.81 \\
0.00 \\
3.77\end{array}$ & $\begin{array}{l}\text { ROTARY } \\
\text { ROTARY } \\
\text { ROTARY } \\
\text { ROTARY } \\
\text { ROTARY AND BAKER MOTOR }\end{array}$ \\
\hline $\begin{array}{l}3897.00 \\
4117.00 \\
4321.00 \\
4544.00 \\
4789.00\end{array}$ & $\begin{array}{l}65.25 \\
66.25 \\
67.25 \\
68.25 \\
69.25\end{array}$ & $\begin{array}{l}132.00 \\
130.00 \\
128.00 \\
127.00 \\
124.00\end{array}$ & $\begin{array}{r}93.00 \\
220.00 \\
204.00 \\
223.00 \\
245.00\end{array}$ & $\begin{array}{r}-4.46 \\
0.45 \\
0.49 \\
0.45 \\
0.41\end{array}$ & $\begin{array}{r}3.2 .3 \\
-0.91 \\
-0.98 \\
-0.45 \\
-1.22\end{array}$ & $\begin{array}{l}\text { ROTARY AND BAKER MOTOR } \\
\text { ROTARY } \\
\text { ROTARY } \\
\text { ROTARY } \\
\text { RC TARY }\end{array}$ \\
\hline 4833.00 & 69.25 & 124.00 & 44.00 & 0.00 & 0.00 & ROTARY \\
\hline
\end{tabular}


Appendix G

HOLE CLEANING 
Hole cleaning was the primary problem in drilling the Boggs \#1240. It was expected that cleaning would be a problem while misting with the motors at high inclinations. When dry air was used, cleaning was generally not a problem. To alleviate hole cleaning problems, the well was drilled with dry air as much as possible; however, it is not possible to drill with motors on dry air. Instead, a stiff foam was used to aid in hole cleaning. The recommended foam mixture and the mud (foam) reports can be found in Appendix $\mathrm{H}$.

Initially, the foam was pumped at a rate of $10 \mathrm{BPH}$ and no hole cleaning problems were noted until the end of the third motor run at $3,165^{\prime}$. There were no problems while drilling, but there were problems pulling the pipe out of the hole during a trip. A total of 4.75 hours were spent circulating and pulling pipe until it came free. The inclination at the end of the build section was $67^{\circ}$. The pipe came free above an inclination of $45^{\circ}$. The measured air rate while drilling with the downhole motor was $1,768 \mathrm{scfm}$ at 520 psi. The foam was injected at a rate of $9 \mathrm{BPH}$.

At the end of the build section, the hole was dried out and dusted to the next motor run. The air rate while drilling was $1,539 \mathrm{scfm}$ at $100 \mathrm{psi}$. No cleaning problems were noted with dry air; however, there was 130 feel of fill on bottom on the next trip in the hole.

The next motor run was made at $3,785^{\prime}$ and the inclination was $72^{\circ}$. Again, there were problems pulling the motor out of the hole after drilling only $70^{\prime}$. The hole became tight after pulling only two stands of pipe (124'). A total of 7.5 hours were spent circulating to clean the hole and pulling pipe while circulating. The air rate for this motor run was $1,400 \mathrm{scfm}$ and the foam rate was $15 \mathrm{BPH}$. The foam rate had been increased to aid in hole cleaning.

After the motor was pulled, the rotary assembly was run back in the hole. This time it was difficult to dry the well out. A total of 24 hours were spent trying to clean the well with foam and then dry it out. The daily reports dated $7 / 27 / 89$ and $7 / 28 / 89$ detail the efforts. Increasing the air rate to $2,300 \mathrm{scfm}$ finally dried the well out and drilling continued to TD.

In order to achieve the $2300 \mathrm{scfm}$, the compressor system plumbing had to be changed The single stage booster could not handle more than 1,500 scfm with four 750 's as the primary. The air system was switched so that the four 750's were sent through the two stage booster and a 1,050 was sent through the single stage booster. This configuration produced only $1,750 \mathrm{scfm}$. The two stage booster would not pump any more than $800 \mathrm{scfm}$ as a two stage or with the valves open as a single stage. The primaries were again switched to where the four 750's were sent to the single stage and the 1,050 was sent to the two stage. The result was 2,300 scfm of air. Without orifice meters on both the inlet and outlet of the boosters, it would not have been possible to determine how to rig up the compressors to get the maximum air rate. In all cases, there was 4,050 scfm worth of rated air entering the boosters. The efficiency of each booster made a significant difference in actual air rates.

The 2,300 scfm was still a minimum required to clean the slant section of the well. Though no problems were encountered while drilling, the TV camera showed there was still a significant amount of dust in the weli. 
The total foam mixed and pumped was 1,375 barrels at a total cost of $\$ 16,523$. The foam cost $\$ 12.02$ per barrel including mixing costs and transportation. All indications are that the stiff foam accomplished very little over using a simple mist. The obvious solution to the hole cleaning problem with mist is to use higher air volumes. Unfortunately, higher air volumes will be detrimental to the life of downhole motors unless a partial bypass can be devised. The higher volumes required at high pressure would also require more than one two stage booster; a significant additional cost.

Hole cleaning is a problem because of the additional time required (and therefore cost) and the possibility of sticking the drill string. To prevent the latter, additional float valves were placed in the drill string. A hammer float was placed on top of the bit with rotary and downhole motor assemblies. A second float valve was placed in the float sub. With motor runs, a third float was placed above the side entry sub to keep the drill string exhausting through the motor during connections.

As experienced previously in the RET \# 1 well, sticking the drill string was possible when the pipe became plugged. As long as the pipe could be circulated, it could always be pulled from the hole. The additional float valves in the Boggs \#1240 were used to prevent any possible plugging of the pipe. There was no indication that the drill string even started to plug; therefore, the extra float valves worked as desired. 
Appendix $\mathrm{H}$

DRILLING MUD REPORTS (FOAM DATA) 

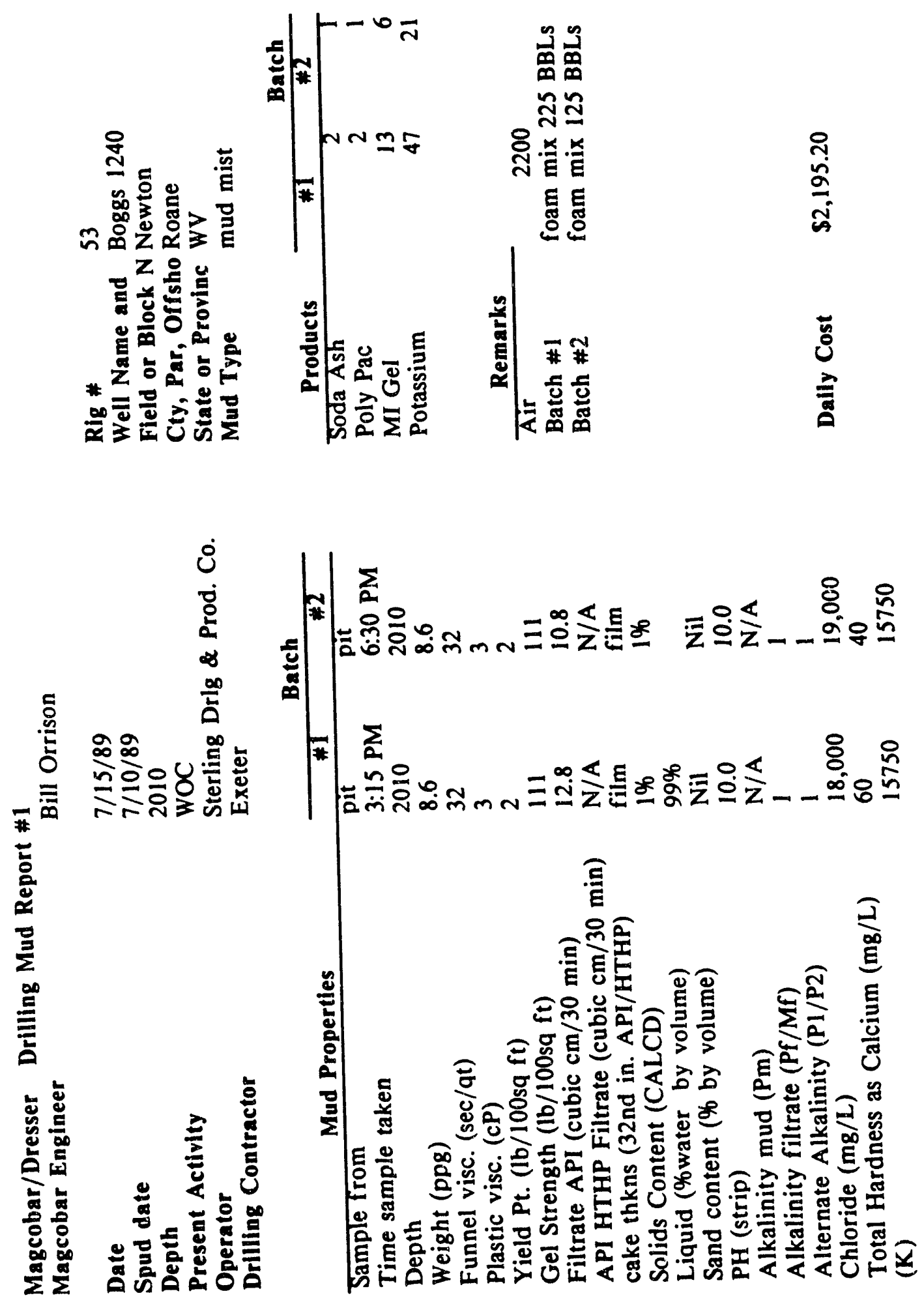

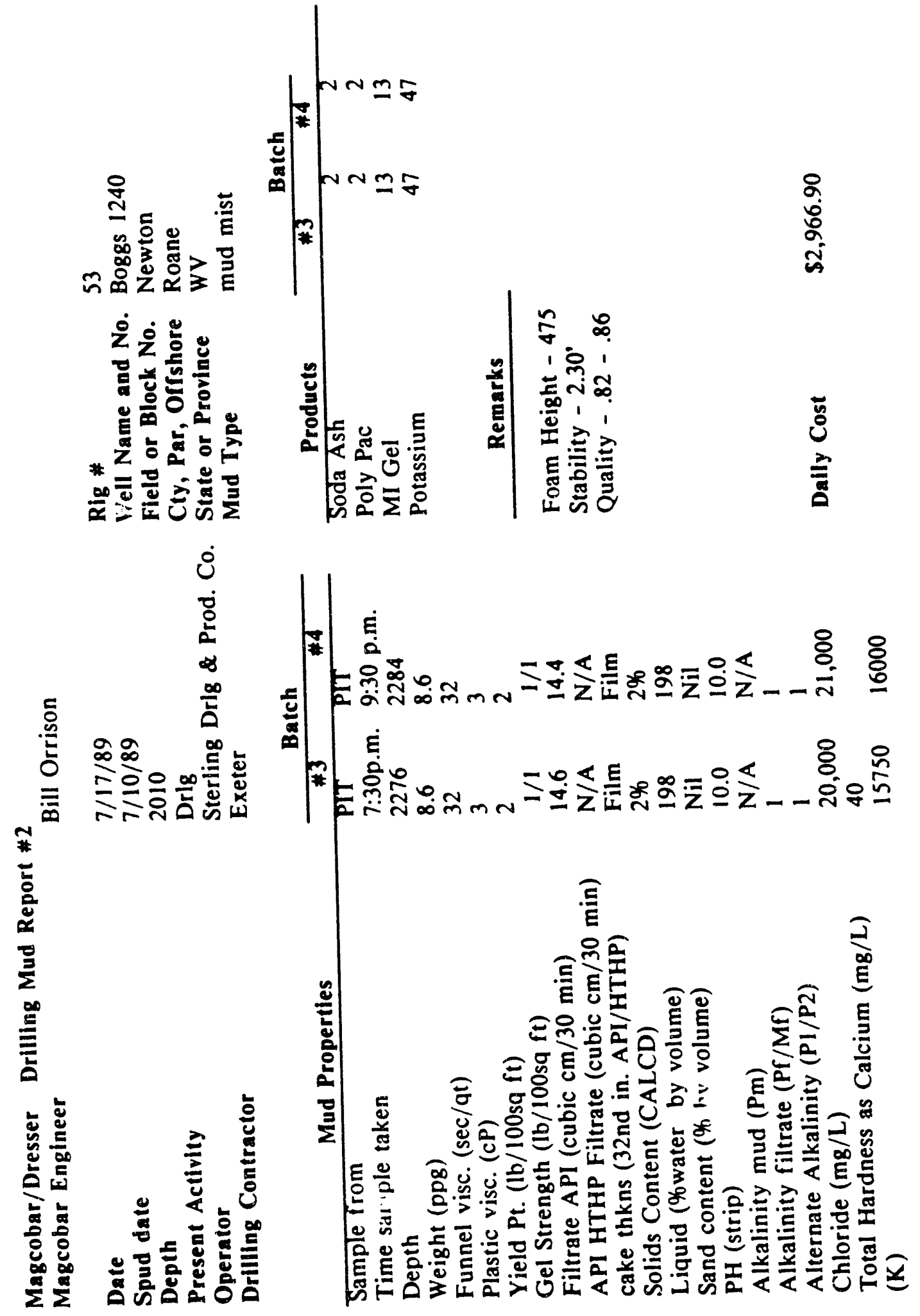

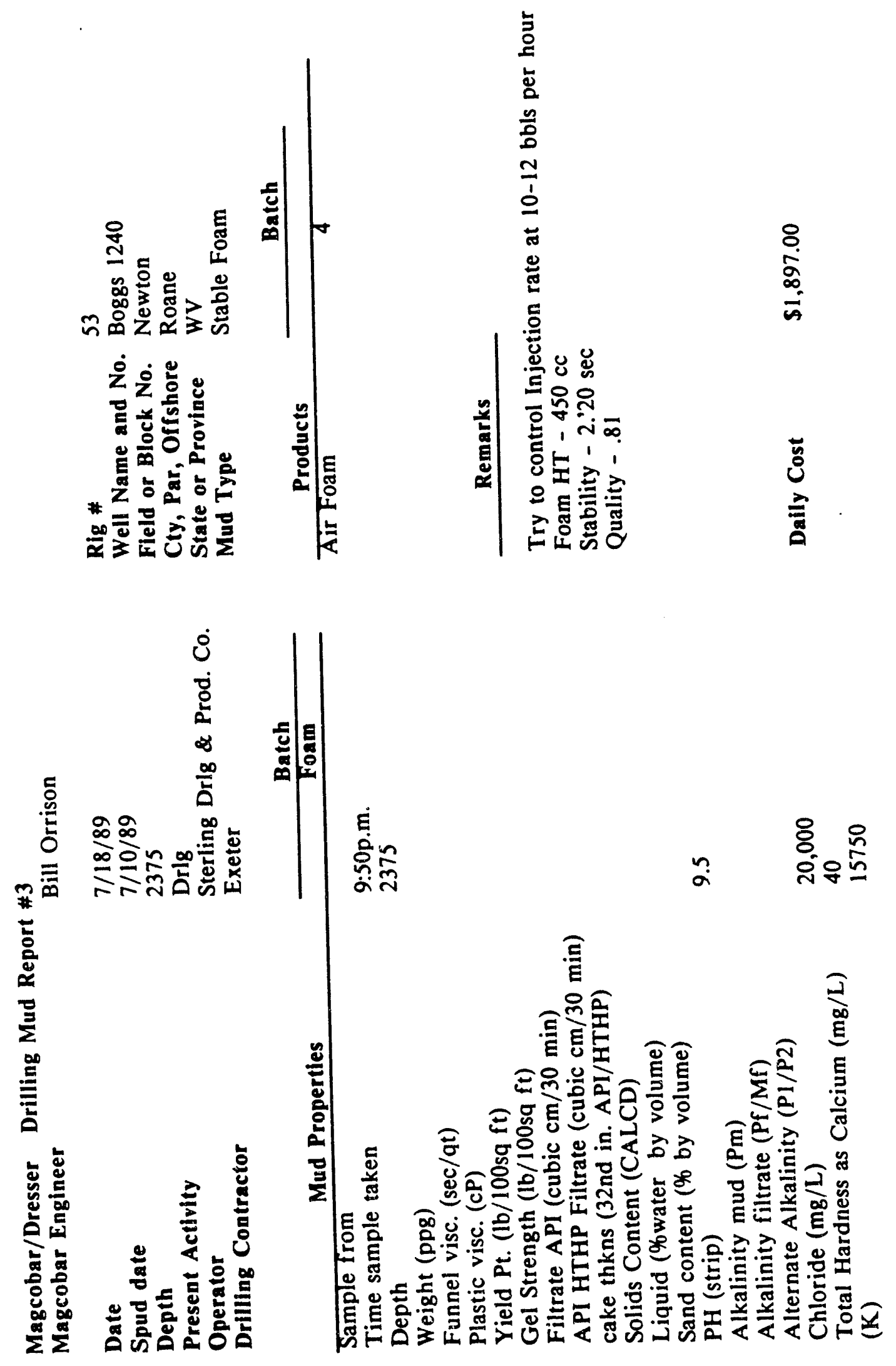

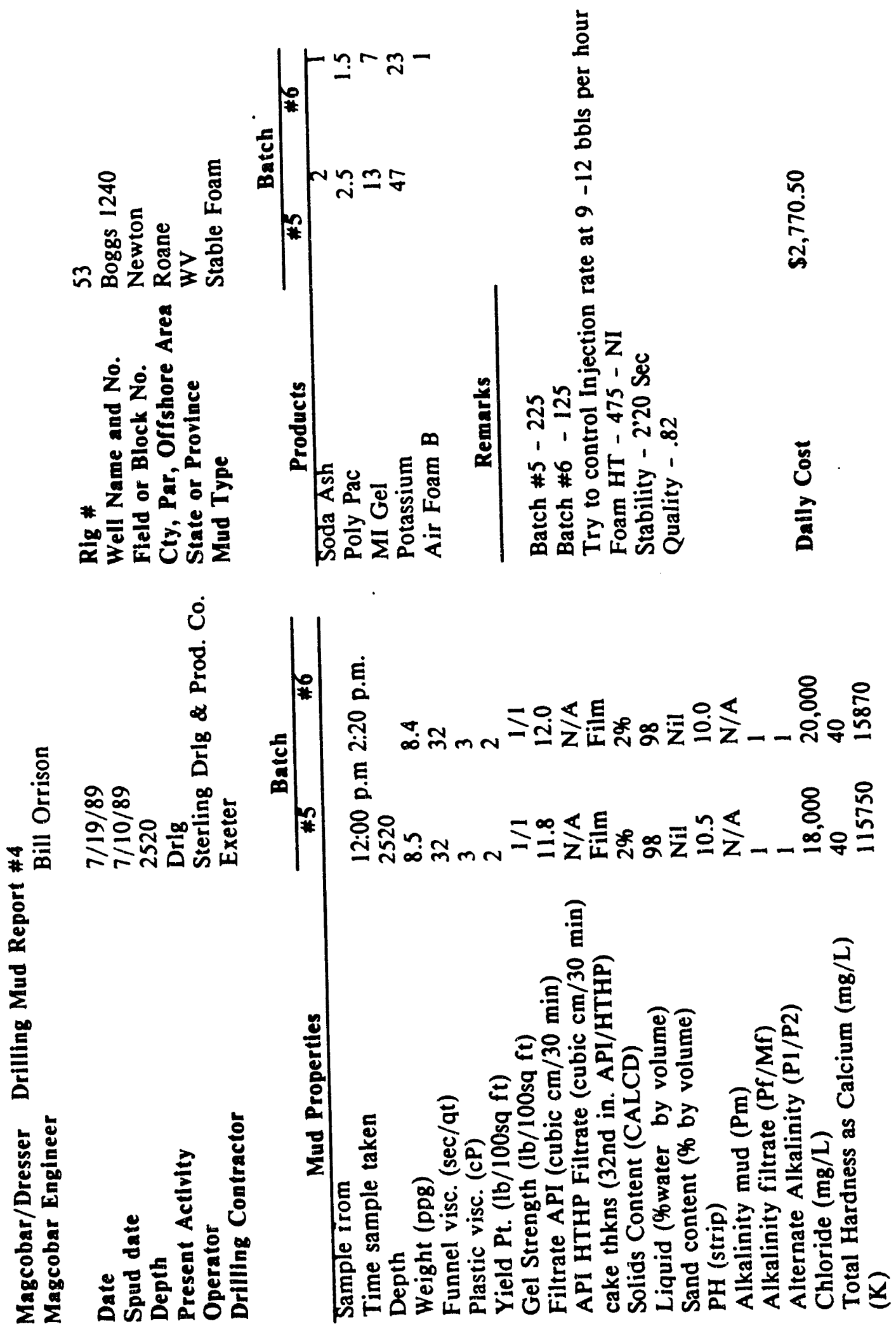

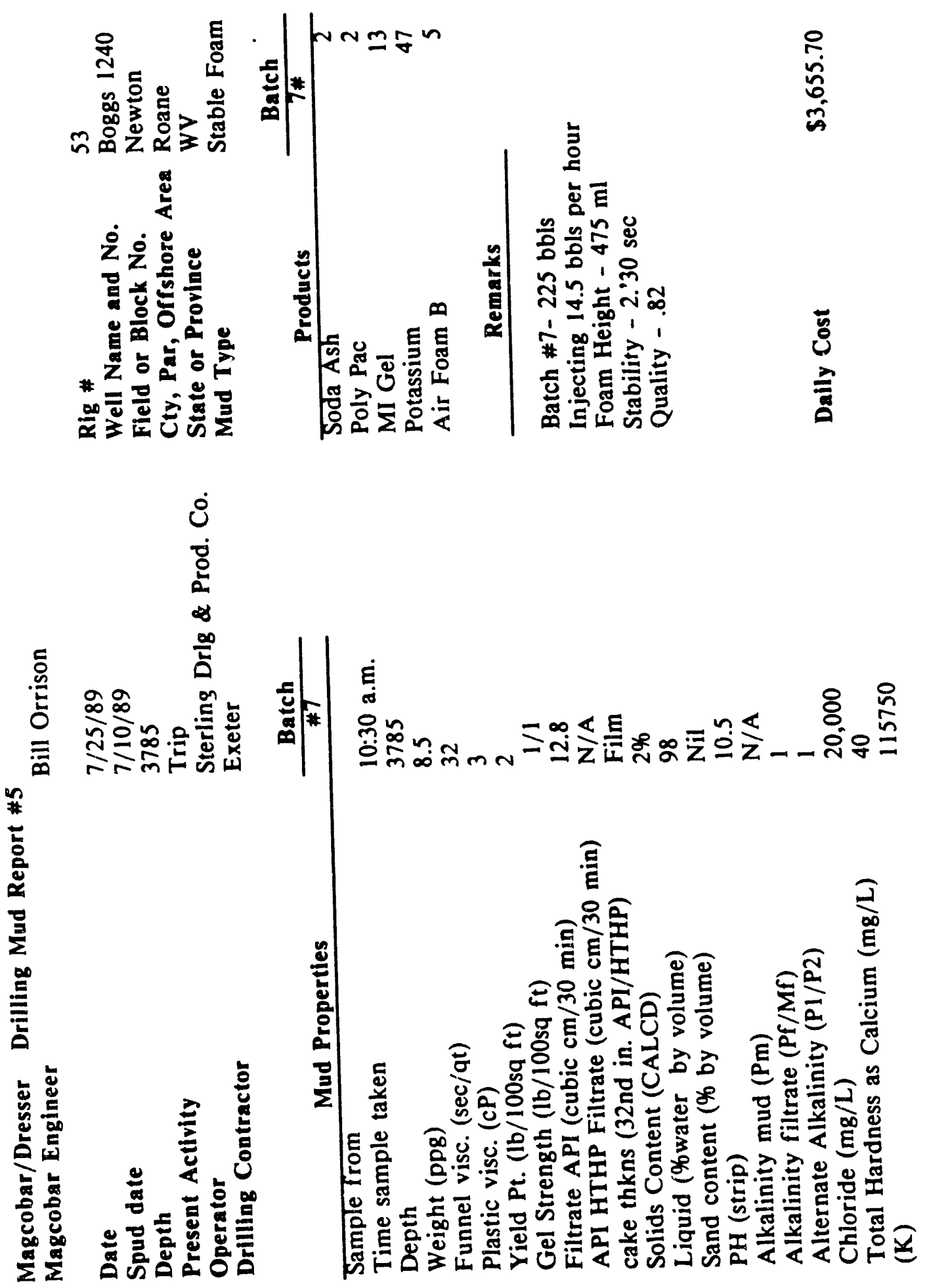
Appendix I

PRESSURE BUILD-UP ANALYSIS 


\section{S. A. Holditch \& Associates, Inc. PETROLEUM ENGINEERING CONSULTANTS}

900 SOUTHWEST PARKWAY EAST. SUITE 200 COLLEGE STATION. TEXAS 77840 (409) 764-1122

July 13,1990

TWX 5108927324

Mr. David Hill

Gas Research Institute

8600 West Bryn Mawr

Chicago, Illinois 60631

Re: Pressure Buildup Analysis

Boggs Well No. 1240

Roane County, WV

Test Date: December 18, 1989 to January 2, 1990

Perforated Interval: 4,618 to 4,624 ft (MD)

Dear David:

Please find attached a final analysis of the pressu: : buildup test conducted on the Boggs Well No. 1240 from December 18, 1989 to January 2, 1990. In a letter dated January 26, 1990, we issued a preliminary analysis of this data along with our recommendations for stimulation. After looking at the data more closely, our analysis and conclusions really didn't change.

Essentially, the perforated interval from 4,618 to $4,624 \mathrm{ft}$ has a permeability-thickness product of $0.2 \mathrm{md}$-ft. If we assume a formation height of $26 \mathrm{ft}$ is contributing to production, the calculated average permeability is $0.0076 \mathrm{md}$ with an apparent skin factor of -2.1 . This indicates the $386 \mathrm{Mscf}$ nitrogen breakdown treatment did stimulate the well, allowing the wellbore to be in good communication with the reservoir. Extrapolating the pressure data, we estimate the initial reservoir pressure was 981 psia.

In February 1990, this interval was stimulated further with 1.3 MMscf of straight nitrogen Whenever it becomes feasible, we would like to run another pressure buildup test on this interval to see the effects of the larger nitrogen treatment.

If you have any questions about this well or analysis, please call.

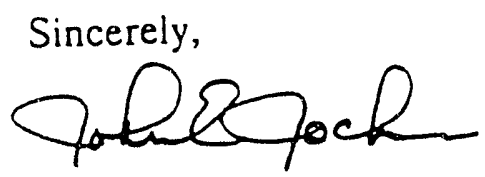

John E. Jochen

Senior Petroleum Engineer, P.E.

\section{$\mathrm{JEJ} / \mathrm{dd}$}

cc: Attached Distribution List 


\section{PRESSURE BUILDUP ANALYSIS \\ STERLING DRILLING \& PRODUCTION COMPANY \\ BOGGS WELL NO. 1240 \\ ROANE COUNTY, WV}

Date: December 18, 1989 to January 2, 1990

Perfs: 4,618 to $4,624 \mathrm{ft}$ (MD)

\section{Introduction}

The Boggs Well No. 1240 is a slanted well with an average inclination through the Devonian Shale interval of approximately 70 o. It was perforated on September 24, 1989 in a six foot interval from 4,618 to $4,624 \mathrm{ft}$ (MD) or 3,494 to $3,496 \mathrm{ft}$ (TVD) with four shots per foot. On September 28,1989 , the zone was treated with $368,000 \mathrm{scf}$ of nitrogen and 500 gal of $7-1 / 2 \% \mathrm{HCl}$ acid. Fig. 1 is a wellbore schematic containing pertinent information at the time the well was perforated. Testing began immediately with a series of flow/shut-in periods. During the final flow period, the well demonstrated the ability to maintain a rate of about 8 to $9 \mathrm{Mscf} / \mathrm{D}$ with about a half barrel of oil swabbed out each day. Following this last flow period, a final pressure buildup test was conducted from December 18, 1989 to January 2, 1990. The buildup test lasted 358.4 hours. The flowing bottomhole pressure at shut-in was 110 psia, and by the end of the buildup test, the bottomhole pressure had increased to 911 psia.

\section{$\underline{\text { Post-Breakdown/Pre-Stimulation Well Test Analvsis }}$}

S. A. Holditch \& Associates, Inc. (SAH) has analyzed the pre-stimulation well test data on the Sterling Drilling \& Production Boggs Well No. 1240. The purpose of our analysis was to determine reservoir properties such as permeability, skin, and initial reservoir pressure.

SAH analyzed the well test data provided to us by Reuben L. Graham, Inc. using conventional techniques (type curve and semi-log "Horner" analysis). We determined that the well did not produce long enough to get past the effects of wellbore storage; therefore, the correct semi-log straight line does not exist on the Homer plot. However, we were able to obtain a good match using type curves, and, therefore, we could determine permeability and skin. We then constructed a straight line on the semi-log plot through the last data point with a slope that would yield the same permeability as that determined from type curves. Extrapolating this straight line to an adjusted Homer time of 1 (i.e., infinite shut-in time), we estimated the initial reservoir pressure.

Fig. 2 shows the pressure buildup data plotted on a log-log scale and matched with the Gringarten et al. type curves. This match results in a permeability-thicknes: roduct, kh, of 0.197 md-ft. Assuming that $26 \mathrm{ft}$ of net pay are contributing to production, the av rage permeability for this interval is 0.0076 md with a calculated apparent skin factor of -2.1 . Fig. 3 show's the same prissure buildup data plotted on a semi-log scale. As can be seen from Fig. 3 , it is not clear when the correct semi-log straight line begins, indicating the data is still being distorted by wellbore storage. The correct semi-log straight line is characteristic of the middle time region (MTR) on a Homer graph indicating the pressure transient has moved into the undarnaged formation. Using the kh deter:nined with type curves, a straight line was drawn on Fig. 3 and extrapolated to an adjusted $\mathrm{F}: \mathrm{m}$.ner time of 1 resulting in an estimated initial reservoir pressure of 981 psia. A detailed printout of the well test data and analysis are attached at the end of this report. 
In general, the pressure drop around the wellbore of a deviated well will be less than that of an equivalent vertical well because the deviated well has more wellbore exposed to the formation. In addition, a well that is not perforated across the entire producing formation (partially completed) will have a greater pressure drop near the wellbore than that of an equivalent filly completed well. Both of these situations exist in the Boggs Well No. 124G. Normally, the apparent skin factor should be corrected for the effects of inclination and partial completion; however, previous research in these areas generally concentrated on damaged formations with little attention to their effects on a stimulated formation.

Since the Boggs Well No. 1240 was broken-down with 368 Mscf of nitrogen, a relatively large treatment for the size of interval completed, the formation should not be damaged. In fact, it should be somewhat stimulated. Analysis of the pressure buildup test results in an apparent skin factor of -2.1 , indicating stimulation. Since previous research did not study the effects of inclination and partial completion on apparent skin factor for a stimulated formation and it was not in the scope of this project to conduct such research, we did not correct the calculated apparent skin factor for the effects of a slanted, partially completed wellbore. Although it might have some effect, we do not believe the effect would change the overall conclusion that the formation was stimulated by the nitrogen breakdown treatment. 
STERLING DRILLING \& PRODUCTION COMPANY

BOGGS NO. 1240

ROANE COUNTY, WEST VIRGINIA

SPUD: 7-10-89

KICK OFF: $7-16-89$

T.D. : 7-29-89

PERF : $9-24-89$

BREAK-DOWN: 9-28-89 w/368 MsCf N2

+500 gal $7 \frac{1}{2} \% \mathrm{HCl}$

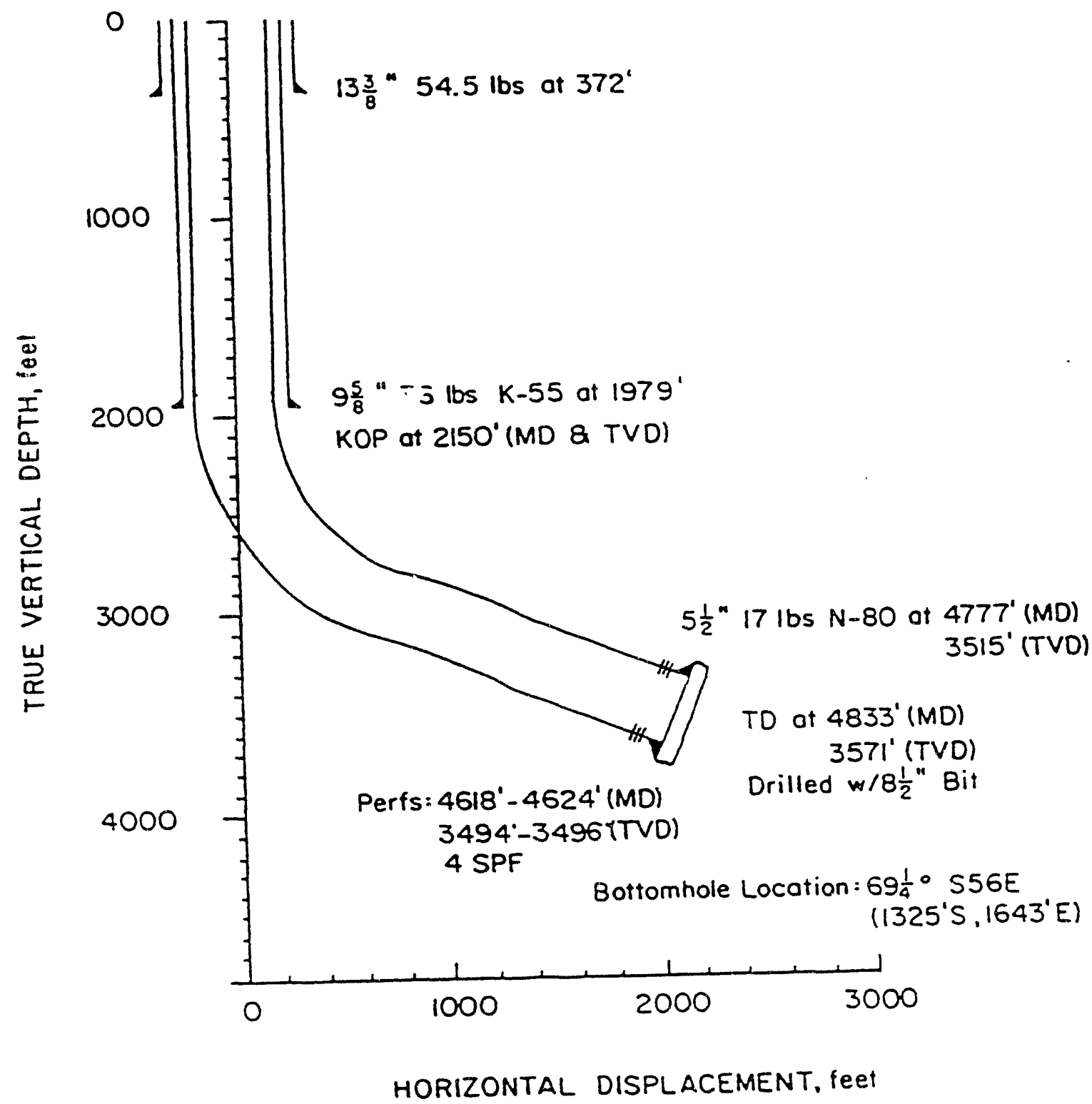

Fig. 1 - Schematic of the Boggs No. 1240 illustrating conditions of the wellbore during initial tests from September 1989 to January 1990. 


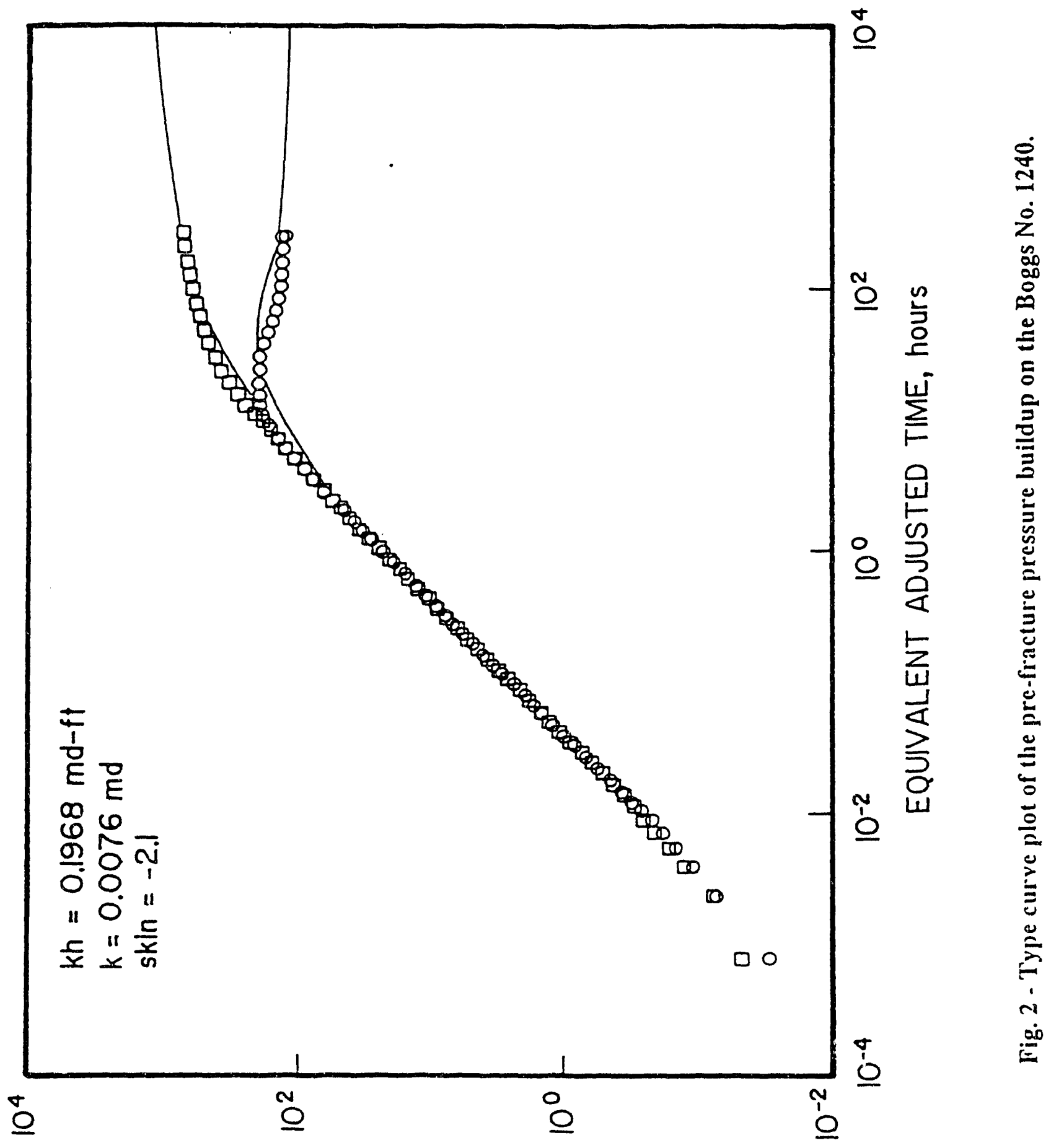

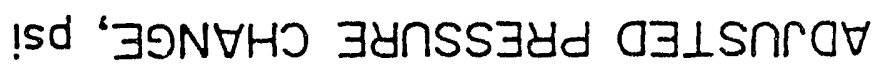




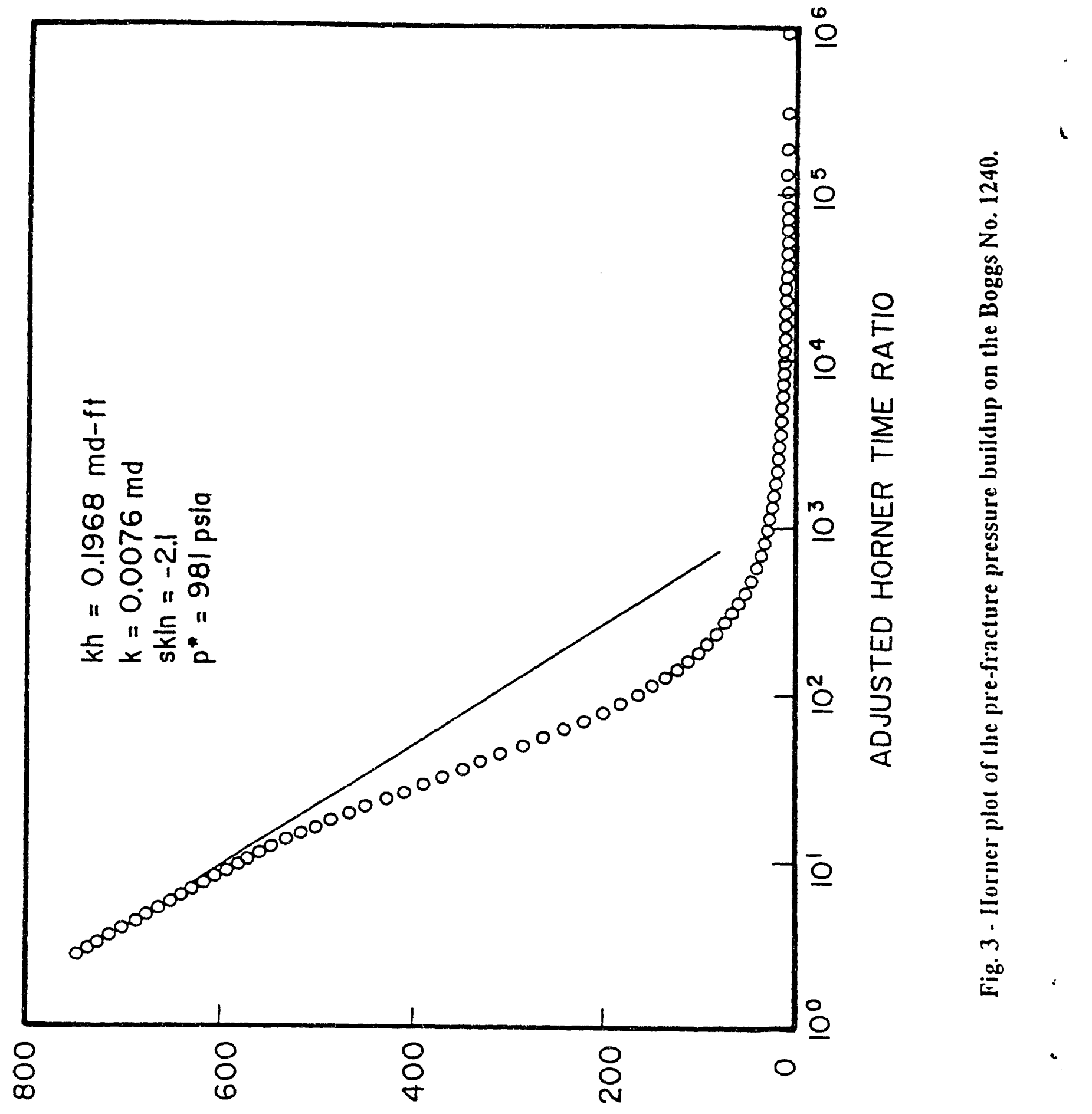

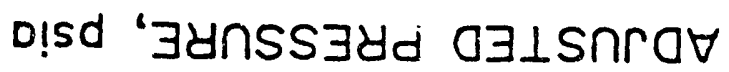


Gas Well Analysis

Buildup Test

Test period preceded by one rate

Operator : Sterling Drilling \& Production Company

PBU26.DA

well : Boggs No. 1240

Location : Roane County, West Virgina

Formation : Devonian Shale

Perforated Interval : 4618-4624 (MD) or 3487-3493 (TVD)

Analyst : jej

Test Date: $12 / 18 / 89$ to $01 / 02 / 90$

Remarks : adjusting producing time for variable producing rates TOTAL INTERVAL $=26 \mathrm{ft}($ TVD) $=72 \mathrm{ft}$ (MD)

\section{RESERVOIR PARAMETERS}

Net pay (ft)

Wellbore radius (ft)

Porosity (fraction)

26.00

.3500

.0410

Gas saturation (fraction)

oil saturation (fraction)

Water saturation (fraction)

Formation compressibility ( $1 / \mathrm{psi})$

Total compressibility ( $1 / \mathrm{psi}$ )

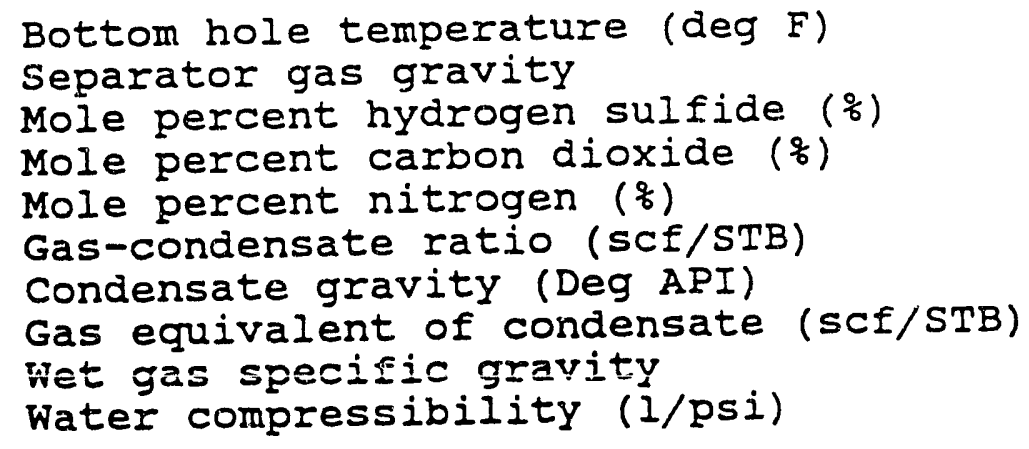

100.00

.6800

.0000

.0000

.0000

10000.0

40.00

615.048

.9970

.0000026 


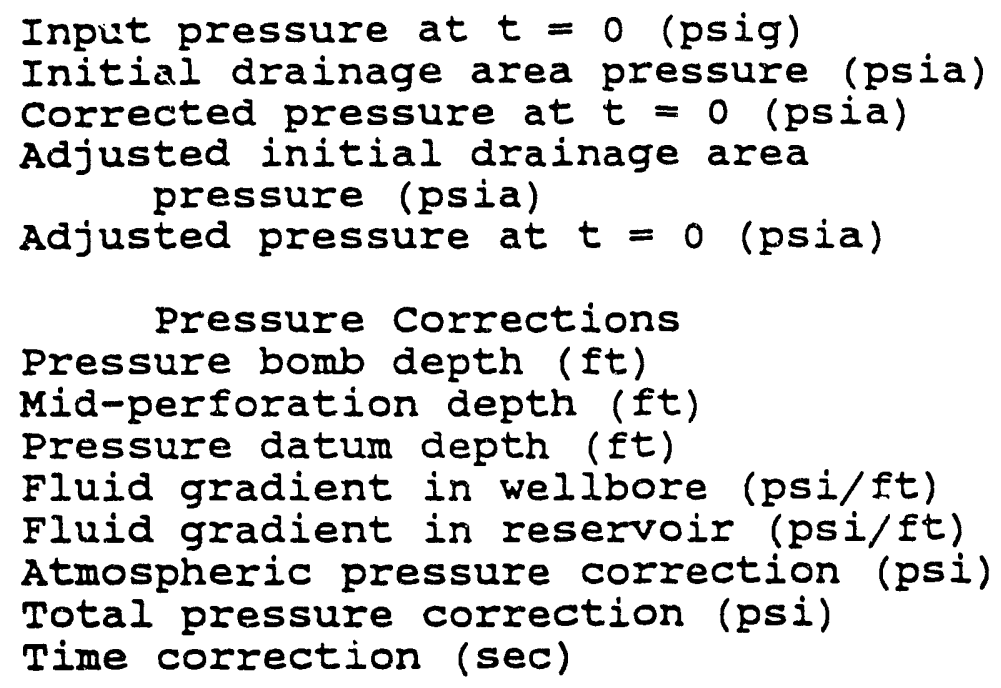

FIUID PROPERTIES AT AVERAGE PRESSURE

Average pressure (psia)

Gas viscosity (cp)

Total compressibility ( $1 / \mathrm{psi}$ )

Z-Factor

Gas formation volume factor (RB/MCf)

Pressure adjustment factor ( $\mathrm{Cp} / \mathrm{psia}$ )

Time adjustment factor ( $\mathrm{pp} / \mathrm{psia}$ )

\section{SEMI-LOG ANALYSIS}

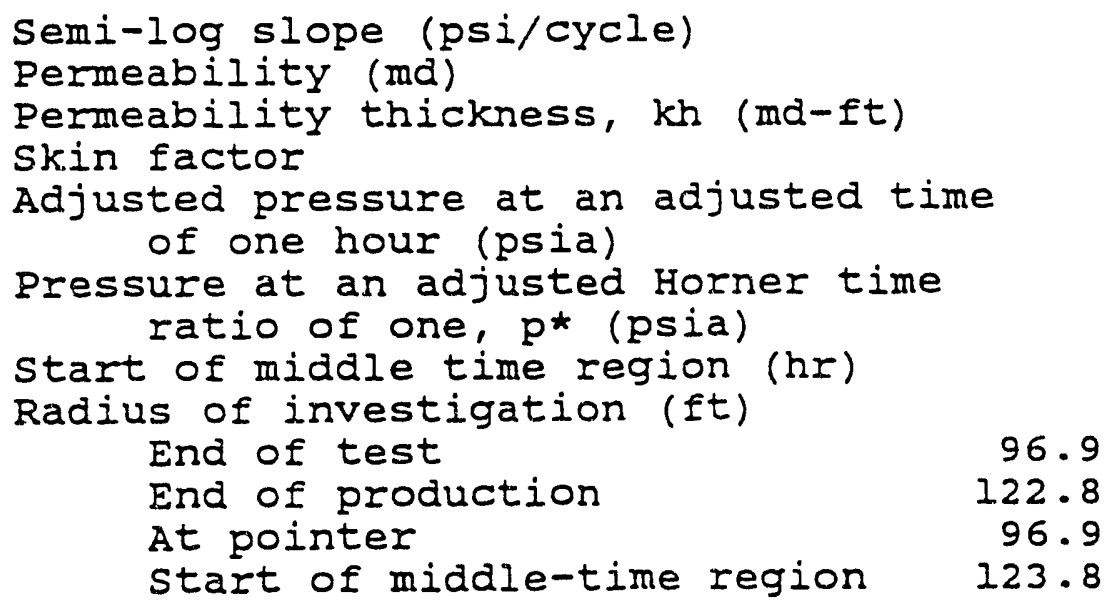

96.9

122.8

96.9

123.8

$$
\begin{array}{r}
-275.96 \\
.0076 \\
.20 \\
-2.117 \\
75.60 \\
980.57 \\
584.825
\end{array}
$$

TYPE CURVE ANAIYSIS - RADIAI FLOW WITH WELIBORE STORAGE AND SKIN 


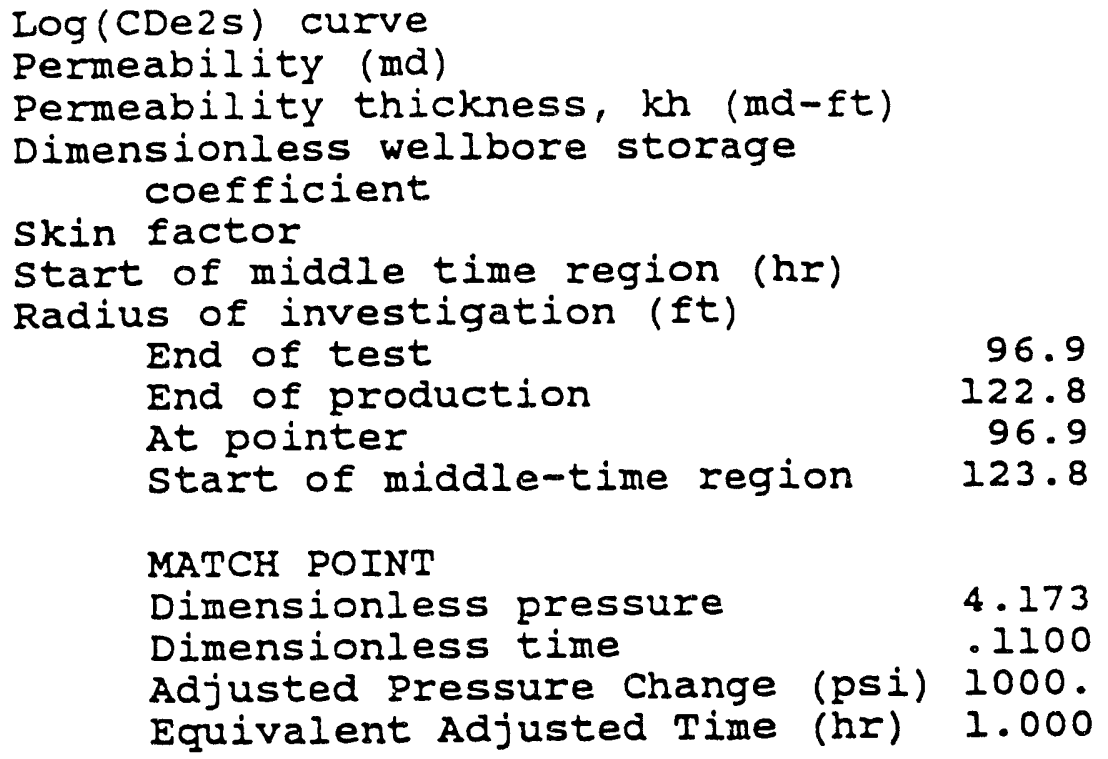

96.9

122.8

96.9

123.8

4.173

.1100

\section{RATE DATA}

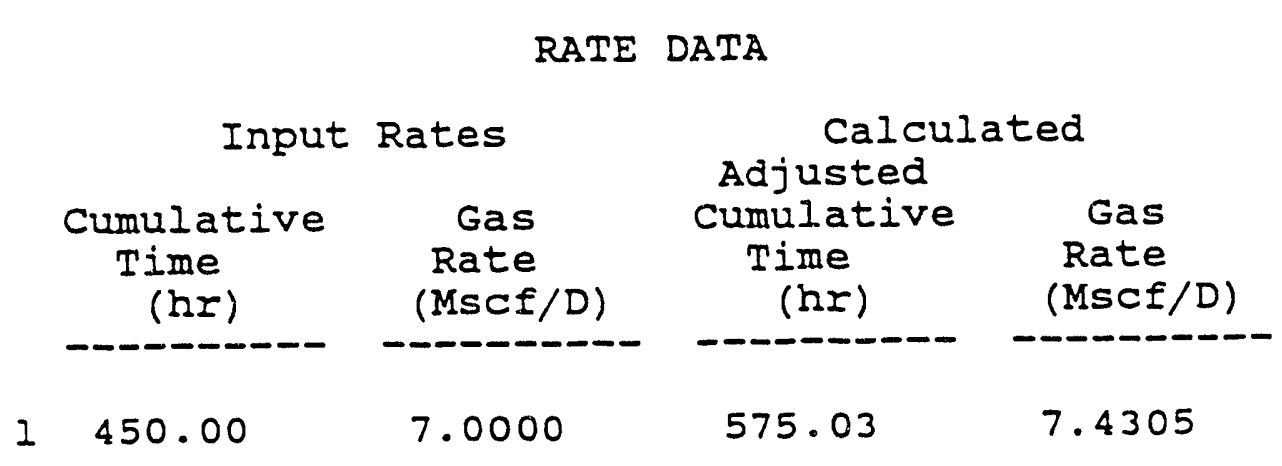

TIME AND PRESSURE DATA

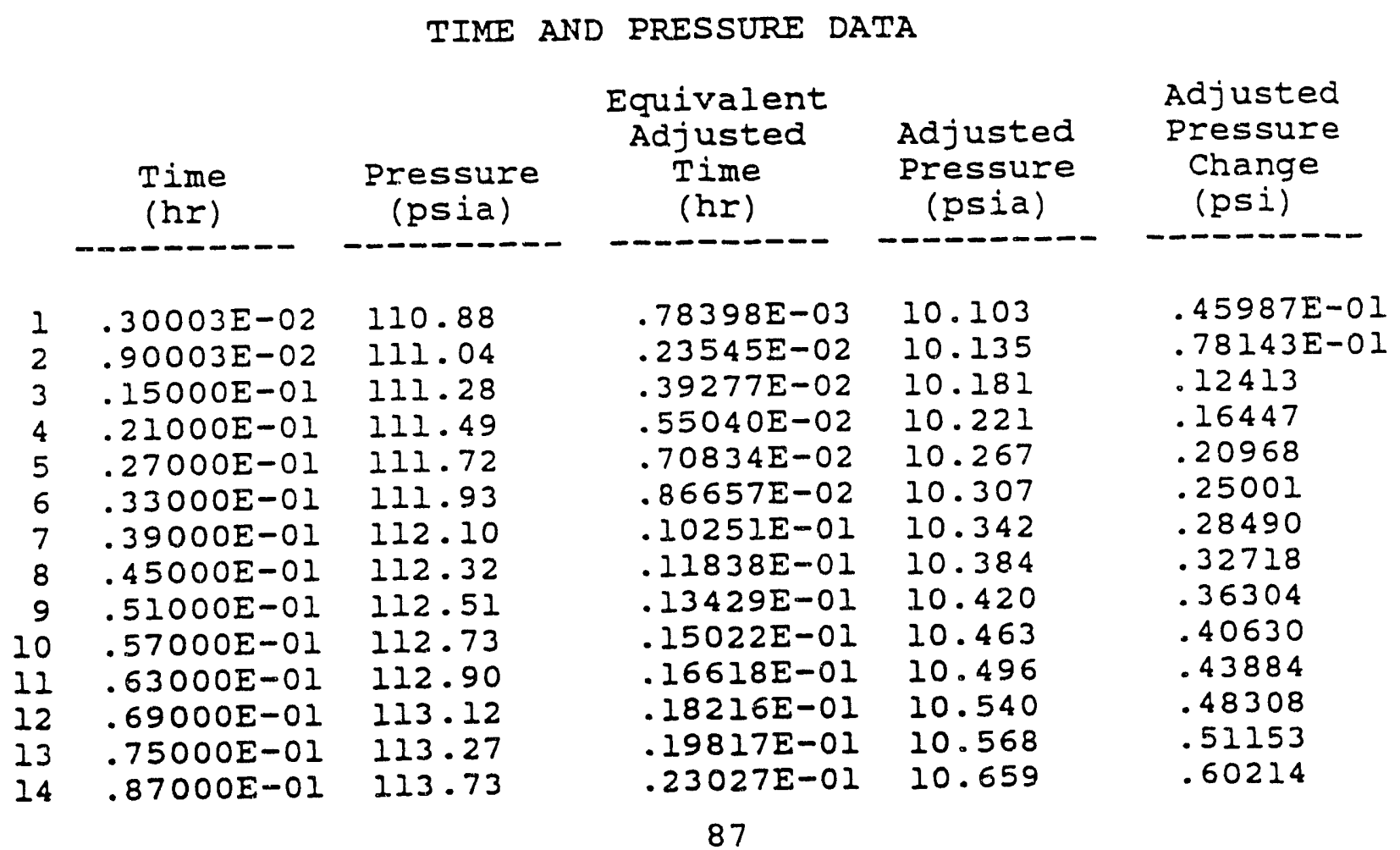

$$
\begin{array}{r}
.8482 \\
.0076 \\
.20 \\
486.60 \\
-2.117 \\
584.825
\end{array}
$$




$\begin{array}{ll}15 & .99000 \mathrm{E}-01 \\ 16 & .11100 \\ 17 & .12300 \\ 18 & .13500 \\ 19 & .14700 \\ 20 & .16500 \\ 21 & .18300 \\ 22 & .20100 \\ 23 & .21900 \\ 24 & .24300 \\ 25 & .26700 \\ 26 & .29100 \\ 27 & .32100 \\ 28 & .35100 \\ 29 & .38700 \\ 30 & .42300 \\ 31 & .46500 \\ 32 & .50700 \\ 33 & .55500 \\ 34 & .60300 \\ 35 & .65700 \\ 36 & .71700 \\ 37 & .78300 \\ 38 & .85500 \\ 39 & .93300 \\ 40 & 1.01-0 \\ 41 & 1.1010 \\ 42 & 1.2030 \\ 43 & 1.3110 \\ 44 & 1.4250 \\ 45 & 1.5510 \\ 46 & 1.6890 \\ 47 & 1.8390 \\ 48 & 2.0010 \\ 49 & 2.1750 \\ 50 & 2.3670 \\ 51 & 2.5710 \\ 52 & 2.7930 \\ 53 & 3.0330 \\ 54 & 3.2970 \\ 55 & 3.5850 \\ 56 & 3.8970 \\ 57 & 4.2330 \\ 58 & 4.5990 \\ 59 & 4.9950 \\ 60 & 5.4270 \\ 61 & 5.9160 \\ 62 & 6.4260 \\ 63 & 7.0040 \\ 64 & 7.6160 \\ 65 & 8.2960 \\ 66 & 9.0100 \\ 67 & 9.7920 \\ 68 & 10.642 \\ 69 & 11.560 \\ 70 & 12.580 \\ 71 & 13.668 \\ 72 & 14.858 \\ & \\ & \\ 18 \\ 130\end{array}$

\begin{tabular}{|c|c|}
\hline $\begin{array}{l}114.09 \\
114.49 \\
114.93 \\
115.32 \\
115.71 \\
116.32 \\
116.88 \\
117.52 \\
118.10 \\
118.90 \\
119.69 \\
120.47 \\
121.49 \\
122.44 \\
123.64 \\
121.81 \\
126.16 \\
127.49 \\
129.07 \\
130.63 \\
132.37 \\
134.28 \\
136.33 \\
138.65 \\
141.15 \\
143.77 \\
146.63 \\
149.69 \\
153.07 \\
156.60 \\
160.52 \\
164.79 \\
169.42 \\
174.36 \\
179.66 \\
185.48 \\
191.60 \\
198.23 \\
205.33 \\
213.05 \\
221.42 \\
230.42 \\
239.94 \\
250.23 \\
261.15 \\
272.84 \\
285.75 \\
298.99 \\
313.53 \\
328.52 \\
344.74 \\
361.39 \\
379.06 \\
397.70 \\
417.07 \\
437.71 \\
458.64 \\
480.35\end{array}$ & 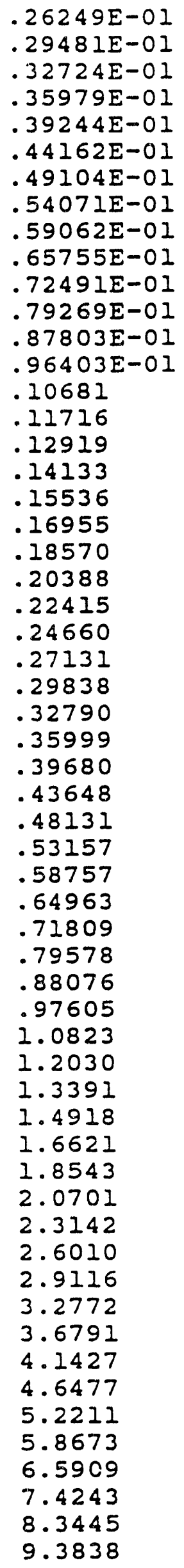 \\
\hline
\end{tabular}

10.729

10.806

10.892

10.968

11.045

11.162

11.273

11.398

11.511

11.666

11.820

11.972

12.181

12.382

12.640

12.890

13.179

13.463

13.800

14.134

14.513

14.957

15.435

15.975

16.557

17.183

17.901

18.672

19.523

20.461

21.526

22.680

24.022

25.455

27.063

28.862

30.844

33.029

35.501

38.265

41.368

44.855

48.714

53.058

57.876

63.264

69.486

76.203

83.945

92.296

101.82

112.06

123.52

136.21

150.10

165.72

182.40

200.60

.67191

.74869

.83560

.91101

.98837

1.1055

1. 2164

1.3407

1.4537

1.6092

1.7630

1.9156

2. 1239

2. 3253

2. 5829

2. 8335

3.1219

3.4065

3.7430

4.0772

4.4564

49004

E 780

5. 9181

6.4998

7.1257

7.8444

$8.6=50$

9.4664

10.404

11.469

12.623

13.965

15.398

17.006

18.805

20.787

22.972

25.444

28.208

31.311

34.798

38.657

43.001

47.820

53.207

59.429

66.147

73.889

82.239

91.764

102.01

113.46

126.15

140.04

155.66

172.35

190.55 


$\begin{array}{llllll}73 & 16.150 & 502.43 & 10.547 & 220.05 & 209.99 \\ 74 & 17.544 & 524.37 & 11.836 & 240.32 & 230.26 \\ 75 & 19.074 & 546.79 & 13.283 & 261.94 & 251.88 \\ 76 & 20.740 & 569.22 & 14.890 & 284.48 & 274.42 \\ 77 & 22.542 & 591.23 & 16.659 & 307.48 & 297.42 \\ 78 & 24.480 & 610.53 & 18.589 & 328.41 & 318.35 \\ 79 & 26.588 & 627.92 & 20.713 & 347.84 & 337.78 \\ 80 & 28.900 & 645.57 & 23.064 & 368.18 & 358.12 \\ 81 & 31.382 & 662.85 & 25.607 & 388.67 & 378.61 \\ 82 & 34.102 & 679.70 & 28.413 & 409.21 & 399.15 \\ 83 & 37.026 & 695.59 & 31.444 & 429.08 & 419.03 \\ 84 & 40.222 & 710.64 & 34.765 & 448.40 & 438.34 \\ 85 & 43.690 & 724.89 & 38.373 & 467.06 & 457.00 \\ 86 & 47.464 & 738.24 & 42.294 & 484.93 & 474.88 \\ 87 & 51.545 & 750.07 & 46.522 & 501.09 & 491.03 \\ 88 & 55.965 & 761.44 & 51.078 & 516.87 & 506.81 \\ 89 & 60.793 & 772.17 & 56.021 & 532.01 & 521.96 \\ 90 & 66.029 & 781.83 & 61.331 & 545.82 & 535.76 \\ 91 & 71.707 & 790.48 & 67.019 & 558.33 & 548.27 \\ 92 & 77.861 & 798.68 & 73.099 & 570.33 & 560.27 \\ 93 & 84.559 & 806.69 & 79.613 & 582.16 & 572.11 \\ 94 & 91.835 & 814.25 & 86.569 & 593.41 & 583.35 \\ 95 & 100.01 & 822.77 & 94.231 & 606.25 & 596.19 \\ 96 & 108.69 & 830.26 & 102.20 & 617.64 & 607.58 \\ 97 & 118.04 & 838.10 & 110.59 & 629.65 & 619.59 \\ 98 & 128.40 & 843.66 & 119.65 & 638.25 & 628.19 \\ 99 & 139.42 & 850.24 & 129.03 & 648.50 & 638.44 \\ 100 & 151.51 & 856.61 & 139.03 & 658.48 & 648.43 \\ 101 & 164.54 & 862.79 & 149.45 & 668.27 & 658.21 \\ 102 & 178.90 & 868.23 & 160.55 & 676.91 & 666.85 \\ 103 & 194.34 & 874.16 & 172.05 & 686.42 & 676.36 \\ 104 & 211.04 & 879.90 & 184.01 & 695.65 & 685.59 \\ 105 & 229.41 & 885.22 & 196.61 & 704.29 & 694.24 \\ 106 & 249.35 & 890.43 & 209.68 & 712.78 & 702.72 \\ 107 & 270.73 & 895.28 & 223.02 & 720.75 & 710.69 \\ 108 & 294.18 & 900.45 & 236.93 & 729.27 & 719.21 \\ 109 & 319.56 & 904.99 & 251.17 & 736.81 & 726.75 \\ 110 & 347.02 & 909.72 & 265.70 & 744.68 & 734.6 .3 \\ 111 & 358.38 & 911.32 & 271.46 & 747.36 & 737.30\end{array}$



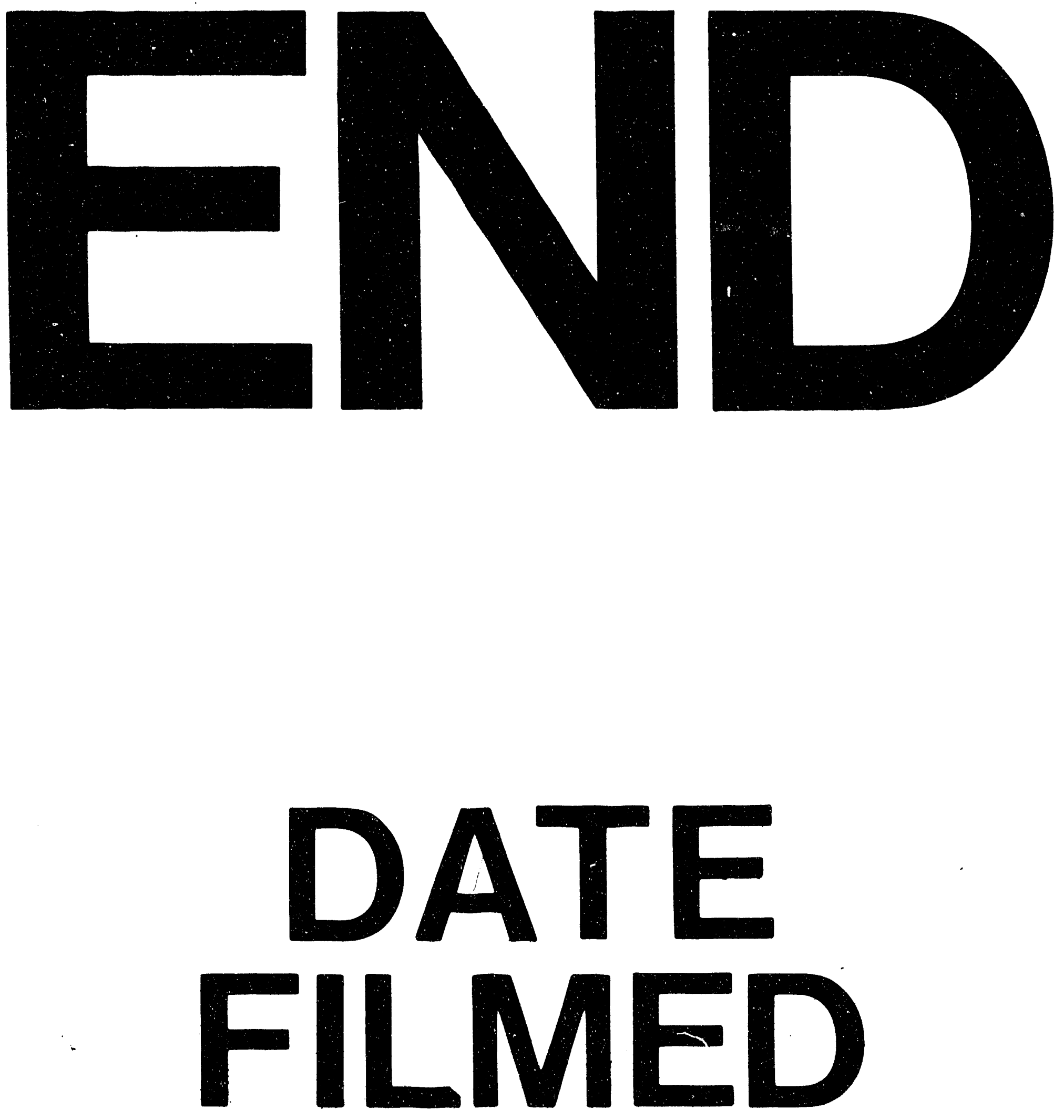

f

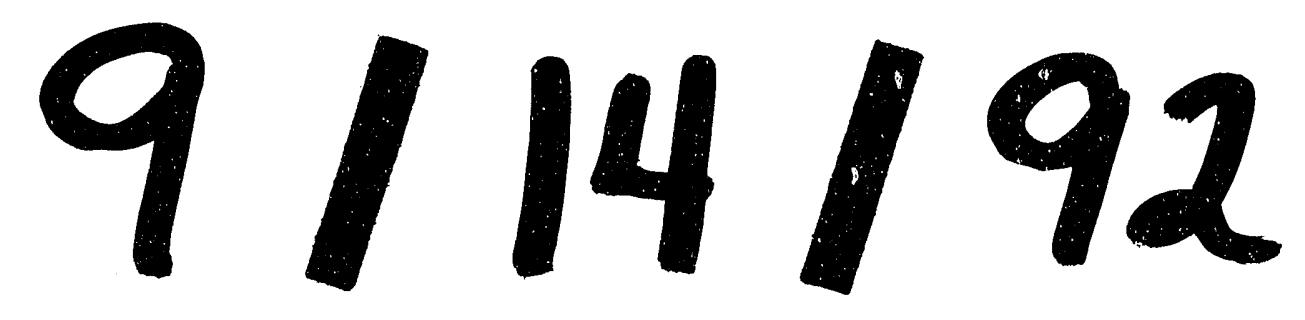


